Prepared in cooperation with the Federal Emergency Management Agency and the New Hampshire Department of Environmental Services

\title{
Analysis of the Transport of Sediment by the Suncook River in Epsom, Pembroke, and Allenstown, New Hampshire, after the May 2006 Flood
}

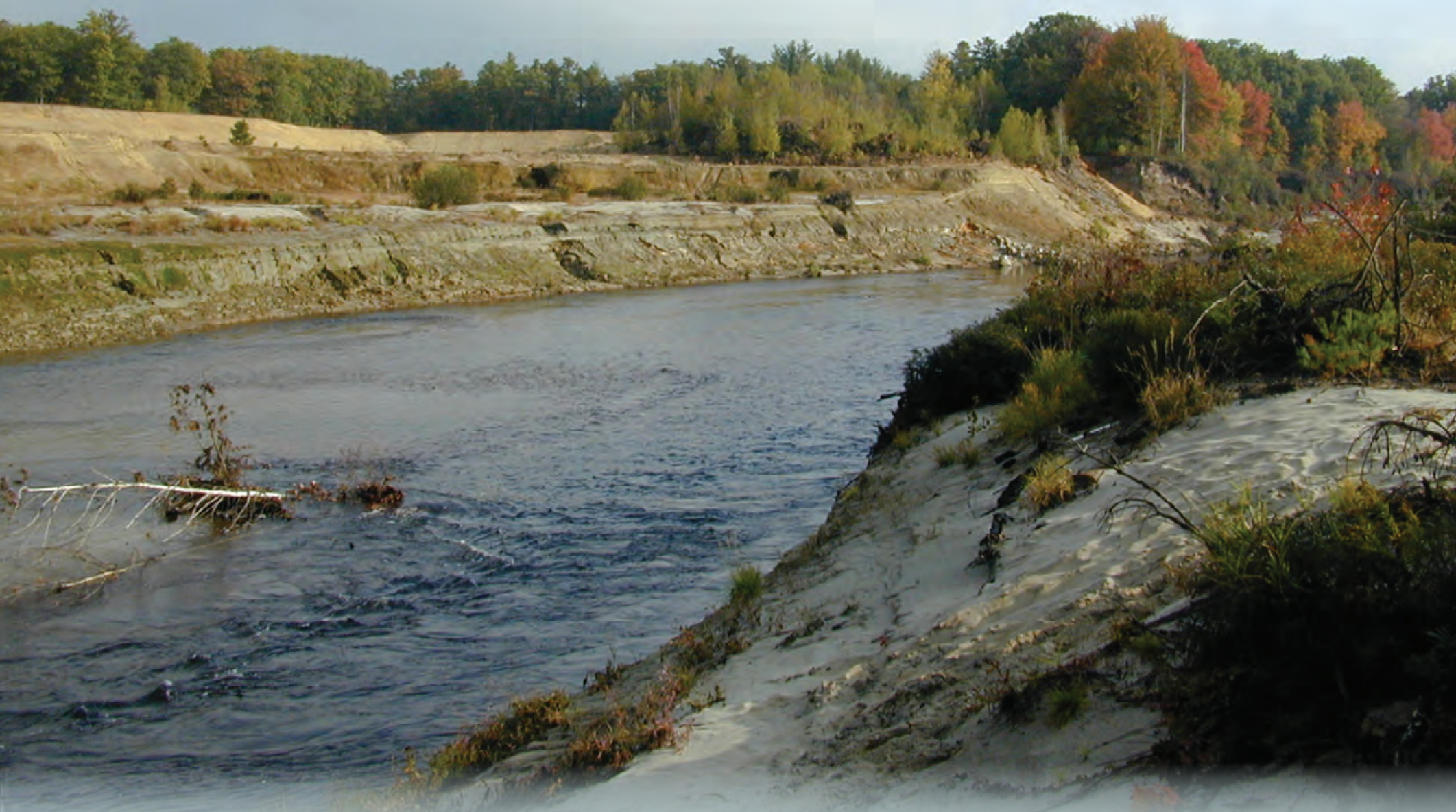

Scientific Investigations Report 2011-5088 
Cover. Photograph looking upstream at the Suncook River avulsion channel through the sand pit, Epsom, New Hampshire. (Photograph taken October 9, 2008) 


\section{Analysis of the Transport of Sediment by the Suncook River in Epsom, Pembroke, and Allenstown, New Hampshire, after the May 2006 Flood}

By Robert H. Flynn

Prepared in cooperation with the Federal Emergency Management Agency and the New Hampshire Department of Environmental Services

Scientific Investigations Report 2011-5088 


\section{U.S. Department of the Interior \\ KEN SALAZAR, Secretary \\ U.S. Geological Survey \\ Marcia K. McNutt, Director}

U.S. Geological Survey, Reston, Virginia: 2011

For more information on the USGS - the Federal source for science about the Earth, its natural and living resources, natural hazards, and the environment, visit http://www.usgs.gov or call 1-888-ASK-USGS.

For an overview of USGS information products, including maps, imagery, and publications, visit http://www.usgs.gov/pubprod

To order this and other USGS information products, visit http://store.usgs.gov

Any use of trade, product, or firm names is for descriptive purposes only and does not imply endorsement by the U.S. Government.

Although this report is in the public domain, permission must be secured from the individual copyright owners to reproduce any copyrighted materials contained within this report.

Suggested citation:

Flynn, R.H., 2011, Analysis of the transport of sediment by the Suncook River in Epsom, Pembroke, and Allenstown, New Hampshire, after the May 2006 flood: U.S. Geological Survey Scientific Investigations Report 2011-5088, 73 p. (Also available at http://pubs.usgs.gov/sir/2011/5088.) 


\section{Acknowledgments}

Support to generate the 1- and 4-foot contour-interval data used in the creation of the flood maps for this study was provided by Eastern Topographics through a New Hampshire Department of Safety-Bureau of Emergency Management Grant (Emergency Management Performance Grant) with in-kind cooperation provided by the New Hampshire Department of Environmental Services through its dam-maintenance efforts in the Suncook River watershed.

The author would like to express appreciation to the following U.S. Geological Survey (USGS) personnel who assisted with collection of data in this report-Thor Smith and Chandlee Keirstead for sediment and flow data collection, Rick Kiah for Acoustic Doppler Current Profiler (ADCP) data collection and postprocessing, James Degnan and Thor Smith for geophysical data collection in the former sand pit and Scott Olson, Heather Manzi, and Glenn Berwick for collection of field-surveyed elevation data. The author would also like to express appreciation to the USGS Kentucky Water Science Center Sediment Laboratory for the analyses of suspended-, bedload- and streambed-sediment samples. 
THIS PAGE INTENTIONALLY LEFT BLANK 


\section{Contents}

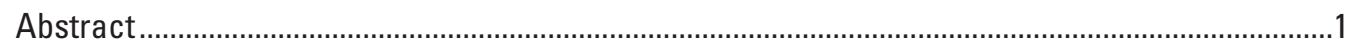

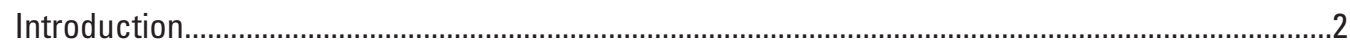

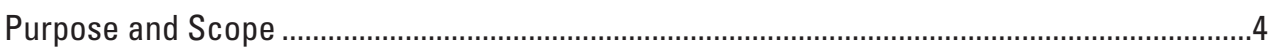

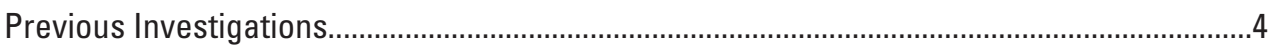

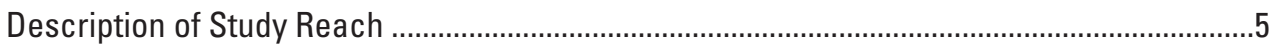

Geohydrology of the Suncook River ...................................................................................

Characterizing Sediment Transport and the River Streambed...............................................12

Channel Equilibrium.................................................................................................. 13

Stream Temperature .................................................................................................

Bankfull Flow as Effective Discharge .........................................................................15

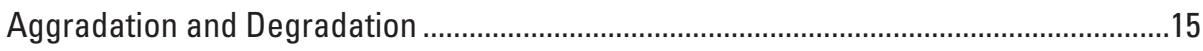

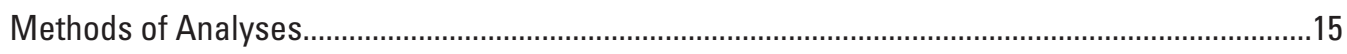

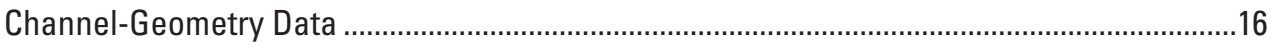

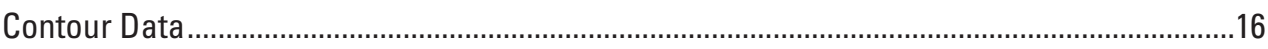

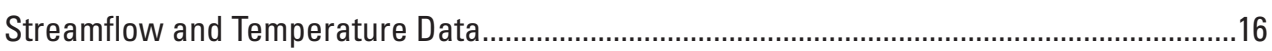

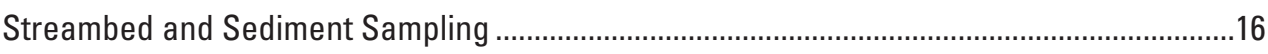

Simulation of Flow and of Sediment Transport .................................................................17

Initial- and Boundary-Condition Data.........................................................................

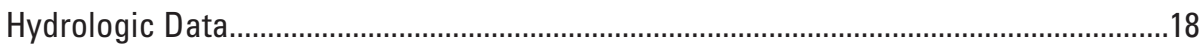

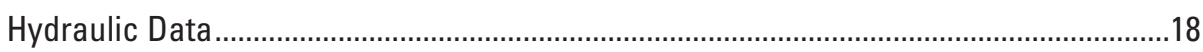

Calibration of the HEC-RAS Hydraulic Model ..................................................................18

HEC-RAS Sediment-Transport Function Selection ............................................................19

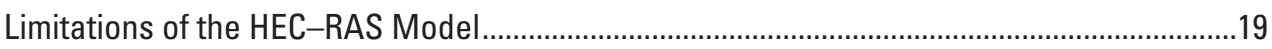

Markov Chain Analyses of Flow .......................................................................................2

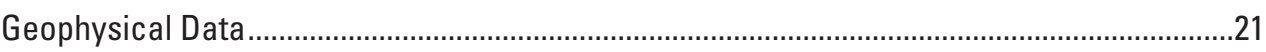

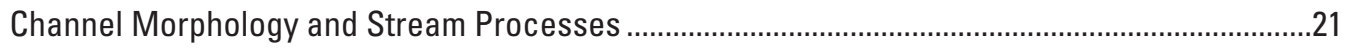

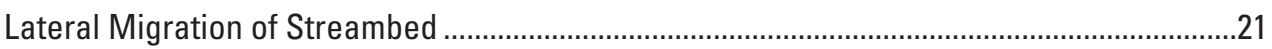

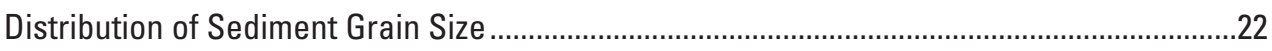

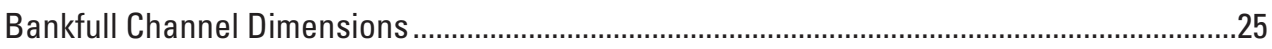

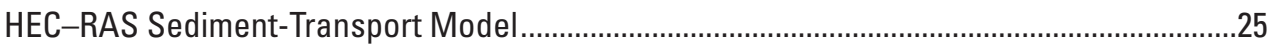

Flood-Generated Shear Stress and the Potential for Entrainment...................................30

Model and Field-Data Sediment-Transport Curves.............................................................34

Simulating Sediment Transport to Investigate the Impact of Future Sediment Loads on Flood Flows ............................................................................................... 40

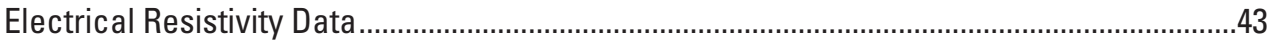

Sediment Load and its Effect on Streambed and Flood Elevations .................................................43

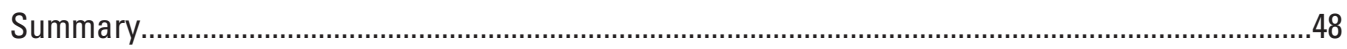

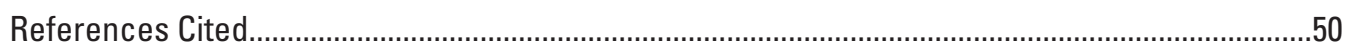

Appendix 1. Particle-Size Gradation and Median Diameter $\left(d_{50}\right)$ of Streambed Sediment

Samples Collected at 30 Locations in the Suncook River 


\section{Figures}

1. Map showing extent of the sediment-transport study of the Suncook River in Epsom, Pembroke, and Allenstown, New Hampshire, 2009-10

2. Preavulsion aerial imagery showing the new and abandoned channels resulting from the May 2006 Suncook River avulsion, Epsom, New Hampshire.

3. Map showing overview of the Suncook River study reach in Epsom, Pembroke, and Allenstown, New Hampshire

4A-D. Aerial imagery showing locations and saturated thicknesses of four stratified-drift aquifers, location of sediment-transport-model cross sections, and locations of 30 streambed-material collection sites along the Suncook River in Epsom, Pembroke, and Allenstown, New Hampshire

5A-B. $\quad A$, May 2007 and $B$, April 2008 aerial imagery of the avulsion and former sand pit showing the May 2007 channel location and geophysical-survey cross sections (lines 1-4) and model cross sections CR through DD $(1: 25,000)$...

6A-C. Graphs showing $A$, streambed-sediment grain-size distribution at six cross sections on the Suncook River upstream of the May 2006 avulsion, $B$, streambed-sediment grain-size distribution at ten cross sections on the Suncook River between the May 2006 avulsion and Short Falls Road Bridge, and C, streambed-sediment grain-size distribution at ten cross sections on the Suncook River downstream of the Short Falls Road Bridge

7. Graph showing median sediment grain sizes $\left(d_{50}\right)$ for the Suncook River in Epsom, Pembroke, and Allenstown, New Hampshire

8. Graphs showing $A$, bankfull-flow mean depth and $B$, bankfull-flow top width of the Suncook River in Epsom, Pembroke, and Allenstown, New Hampshire...

9. Graph showing Suncook River streambed thalweg elevation between the Buck Street Dams and the Short Falls Road Bridge as surveyed on June 11, 2009, and as model-predicted using the Laursen (Copeland) sediment-transport function.

10. Graph showing measured vs. simulated streambed thalweg-elevation changes for the Suncook River from the Buck Street Dams to the Short Falls Road Bridge, Epsom and Pembroke, New Hampshire, June 11, 2009

11A. Graph showing distribution of streambed shear stress in the Suncook River for the 50-, 10- and 1-percent annual exceedence probability floods, and of critical streambed shear stress based on the $d_{50}$ (cross sections A to BL)...

11B. Graph showing distribution of streambed shear stress in the Suncook River for the 50-, 10- and 1-percent annual exceedence probability flood, and of critical streambed shear stress based on the $d_{50}$ (cross sections BL to DW).

12A-B. Scatterplots showing sediment-transport curve for Suncook River at $A$, Route 3 bridge, and $B$, Route 28 bridge .

12C-D. Scatterplots showing sediment-transport curve for Suncook River at $C$, Short Falls Road Bridge, and $D$, Route 4 bridge.

13A-B. Graphs showing thalweg elevations of the Suncook River streambed from data published in May 2008 and in 1978 Flood Insurance Studies and from model predictions for end of water year 2010 in $A$, cross sections $A$ to $A \mathrm{l}$, and $B$, cross sections AJ to $B T$.....

13C-D. Graphs showing thalweg elevations of the Suncook River streambed from data published in May 2008 and in 1978 Flood Insurance Studies and from model predictions for end of water year 2010 in $C$, cross sections $\mathrm{BU}$ to $\mathrm{DQ}$, and $D$, cross sections DR to DW 
14A-B. Cross sections showing electrical resistivity geophysical survey transect for $A$, line 2 , and $B$, line 4 .

15. Graph showing Suncook River mean and median of the daily sediment discharges for water year 2009 using the Laursen (Copeland) function.

\section{Tables}

1. Population information for the towns in the Suncook River study area.

2. Bankfull-flow mean depth and top width of the Suncook River in Epsom, Pembroke, and Allenstown, New Hampshire

3. Field-collected total sediment loads and estimates of total sediment loads from sediment-transport curves.

4. Streambed thalweg elevations for the Suncook River, New Hampshire, study reach, surveyed $(2008,2009)$ and modeled $(2009)$ using the Hydrologic Engineering Center River Analysis System (HEC-RAS) during a 400-day calibration, May 8, 2008June 11, 2009

5. Daily mean shear stress at four total sediment-load collection locations, Suncook River, Epsom to Allenstown, New Hampshire, during May 2008-end of water year 2009

6. Distribution of streambed shear stress in the Suncook River for the 50-, 10- and 1-percent annual exceedence probability flood

7. Comparison of Hydrologic Engineering Center-River Analysis System (HEC-RAS)predicted flood elevations for 2008 and the end of water year 2010 for the 50-, 10-, 2-, 1-, and 0.2-percent annual exceedence probability floods and streambed elevations at each cross section.

8. Hydrologic Engineering Center-River Analysis System (HEC-RAS)-predicted changes in water-surface elevation and in thalweg elevation above and below the avulsion and between Short Falls Road and Buck Street Dams from 2008 through the end of water year 2010 .

9. Suncook River mean and median of the daily sediment discharges for water year 2009 using the Laursen (Copeland) function. 


\section{Conversion Factors, Datum, and Abbreviations}

\begin{tabular}{lcl}
\hline \multicolumn{1}{c}{ Multiply } & By & \multicolumn{1}{c}{ To obtain } \\
\hline inch (in.) & Length & \\
inch (in.) & 2.54 & centimeter $(\mathrm{cm})$ \\
foot (ft) & 25.4 & millimeter $(\mathrm{mm})$ \\
mile (mi) & 0.3048 & meter $(\mathrm{m})$ \\
\hline \multicolumn{3}{c}{ Area } \\
\hline square mile $\left(\mathrm{mi}^{2}\right)$ & 1.609 & kilometer $(\mathrm{km})$ \\
\hline \multicolumn{3}{c}{ Volume } \\
\hline cubic yard $\left(\mathrm{yd}^{3}\right)$ & 0.7646 & \\
\hline & Flow rate & \\
\hline foot per second $(\mathrm{ft} / \mathrm{s})$ & 0.3048 & cubic meter $\left(\mathrm{m}^{3}\right)$ \\
cubic foot per second $\left(\mathrm{ft}^{3} / \mathrm{s}\right)$ & 0.02832 & cubic meter per second $\left(\mathrm{m}^{3} / \mathrm{s}\right)$ \\
mile per hour $(\mathrm{mi} / \mathrm{h})$ & 1.609 & kilometer per hour $(\mathrm{km} / \mathrm{h})$ \\
\hline & Hydraulic gradient & \\
\hline foot per mile $(\mathrm{ft} / \mathrm{mi})$ & 0.1894 & meter per kilometer $(\mathrm{m} / \mathrm{km})$ \\
\hline & Pressure \\
\hline pound per square foot $\left(\mathrm{lb} / \mathrm{ft}^{2}\right)$ & 0.04788 & \\
\hline
\end{tabular}

Temperature in degrees Celsius $\left({ }^{\circ} \mathrm{C}\right)$ may be converted to degrees Fahrenheit $\left({ }^{\circ} \mathrm{F}\right)$ as follows:

$$
{ }^{\circ} \mathrm{F}=\left(1.8 \times{ }^{\circ} \mathrm{C}\right)+32
$$

Temperature in degrees Fahrenheit $\left({ }^{\circ} \mathrm{F}\right)$ may be converted to degrees Celsius $\left({ }^{\circ} \mathrm{C}\right)$ as follows:

$$
{ }^{\circ} \mathrm{C}=\left({ }^{\circ} \mathrm{F}-32\right) / 1.8
$$

Horizontal coordinate information is referenced to the North American Datum of 1927 (NAD 27) and the North American Datum of 1983 (NAD 83).

Vertical coordinate information is referenced to the National Geodetic Vertical Datum of 1929 (NGVD 29) and the North American Vertical Datum of 1988 (NAVD 88). 


\section{Acronyms}

$\begin{array}{ll}\text { ADCP } & \text { acoustic doppler current profiler } \\ \text { ASCE } & \text { American Society of Civil Engineers } \\ \text { CCO } & \text { Consultation Coordination Officer } \\ \text { CDP } & \text { census-designated place } \\ \text { FEMA } & \text { Federal Emergency Management Agency } \\ \text { FIRM } & \text { flood insurance rate map } \\ \text { FIS } & \text { flood insurance study } \\ \text { GPS } & \text { global positioning system } \\ \text { HEC-RAS } & \text { Hydrologic Engineering Center-River Analysis System } \\ \text { NFIP } & \text { National Flood Insurance Program } \\ \text { NHDES } & \text { New Hampshire Department of Environmental Services } \\ \text { NHDOT } & \text { New Hampshire Department of Transportation } \\ \text { NWIS } & \text { National Water Information System } \\ \text { RMSE } & \text { root mean square error } \\ \text { USACE } & \text { U.S. Army Corps of Engineers } \\ \text { USEPA } & \text { U.S. Environmental Protection Agency } \\ \text { USGS } & \text { U.S. Geological Survey }\end{array}$


THIS PAGE INTENTIONALLY LEFT BLANK 


\title{
Analysis of the Transport of Sediment by the Suncook River in Epsom, Pembroke, and Allenstown, New Hampshire, after the May 2006 Flood
}

\author{
By Robert H. Flynn
}

\section{Abstract}

During May 13-16, 2006, rainfall in excess of 8.8 inches flooded central and southern New Hampshire. On May 15, 2006, a breach in a bank of the Suncook River in Epsom, New Hampshire, caused the river to follow a new path. In order to assess and predict the effect of the sediment in, and the subsequent flooding on, the river and flood plain, a study by the U.S. Geological Survey (USGS) characterizing sediment transport in the Suncook River was undertaken in cooperation with the Federal Emergency Management Agency (FEMA) and the New Hampshire Department of Environmental Services (NHDES).

The U.S. Army Corps of Engineers (USACE) Hydrologic Engineering Center-River Analysis System (HEC-RAS) model was used to simulate flow and the transport of noncohesive sediments in the Suncook River from the upstream corporate limit of Epsom to the river's confluence with the Merrimack River in the Village of Suncook (Allenstown and Pembroke, N.H.), a distance of approximately 16 miles. In addition to determining total sediment loads, analyses in this study reflect flooding potentials for selected recurrence intervals that are based on the Suncook River streamgage flow data (streamgage 01089500) and on streambed elevations predicted by HECRAS for the end of water year 2010 (September 30, 2010) in the communities of Epsom, Pembroke, and Allenstown.

This report presents changes in streambed and watersurface elevations predicted by the HEC-RAS model using data through the end of water year 2010 for the 50-, 10-, 2-, 1-, 0.2 -percent annual exceedence probabilities (2-, 10-, 50-, 100-, and 500-year recurrence-interval floods, respectively), calculated daily and annual total sediment loads, and a determination of aggrading and degrading stream reaches. The model was calibrated and evaluated for a 400-day span from May 8, 2008 through June 11, 2009; these two dates coincided with field collection of stream cross-sectional elevation data. Seven sediment-transport functions were evaluated in the model with the Laursen (Copeland) sediment-transport function best describing the sediment load, transport behavior, and changes in streambed elevation for the specified spatial and temporal conditions of the 400-day calibration period.

Simulation results from the model and field-collected sediment data indicate that, downstream of the avulsion channel, for the average daily mean flow during the study period, approximately 100 to 400 tons per day of sediment (varying with daily mean flow) was moving past the Short Falls Road Bridge over the Suncook River in Epsom, while approximately 0.05 to 0.5 tons per day of sediment was moving past the Route 28 bridge in Pembroke and Allenstown, and approximately 1 to 10 tons per day was moving past the Route 3 bridge in Pembroke and Allenstown. Changes in water-surface elevation that the model predicted for the end of water year 2010 to be a result of changes in streambed elevation ranged from a mean increase of 0.20 feet ( $\mathrm{ft}$ ) for the 50-percent annual exceedence-probability flood (2-year recurrence-interval flood) due to an average thalweg increase of $0.88 \mathrm{ft}$ between the Short Falls Road Bridge and the Buck Street Dams in Pembroke and Allenstown to a mean decrease of $0.41 \mathrm{ft}$ for the 50-percent annual exceedence-probability flood due to an average thalweg decrease of $0.49 \mathrm{ft}$ above the avulsion in Epsom.

An analysis of shear stress (force created by a fluid acting on sediment particles) was undertaken to determine potential areas of erosion and deposition. Based on the median grain size $\left(d_{50}\right)$ and shear stress analysis, the study found that in general, for floods greater than the 50-percent annual exceedence probability flood, the shear stress in the streambed is greater than the critical shear stress in much of the river study reach. The result is an expectation of streambed-sediment movement and erosion even at high exceedence-probability events, pending although the stream ultimately attains equilibrium through stream-stabilization measures or the adjustment of the river over time. The potential for aggradation in the Suncook River is greatest in the reach downstream of the avulsion. Specifically, these reaches are (1) downstream of the former sand pit from adjacent to Round Pond to downstream of the flood chute at the large meander bends, and (2) downstream of the Short Falls Road Bridge to approximately $3,800 \mathrm{ft}$ upstream of the Route 28 bridge. The potential for degradation - net lowering of the streambed - is greatest for the reach upstream of the avulsion to the Route 4 bridge. 


\section{Introduction}

The Suncook River drains a group of lakes to the south of Lake Winnipesaukee in New Hampshire and flows southwest for approximately 30 miles (mi) to the confluence with the Merrimack River at a location between Concord and Manchester, New Hampshire (fig. 1). During May 13-16, 2006, significant flooding occurred in central and southern New Hampshire as a result of rainfall in excess of 8.8 inches (in.) (measured in Concord). On May 15, a breach in the bank of the Suncook River south of U.S. Route 4 and east of State Route 28 caused the Suncook River in Epsom, N.H., to follow a new path through an abandoned sand pit (fig. 2). Before this flood, the Suncook River flowed southward around Bear Island in two stream reaches that rejoined west of Round Pond. The breach resulted in a new channel upstream of Bear Island and two dams at the north end of the island. The new channel rejoins the old channel to the east of the island. After May 16, there was no flow in the former western and northeastern reaches of the Suncook River around Bear Island.

The U.S. Geological Survey (USGS), in cooperation with the New Hampshire Department of Environmental Services (NHDES) and the Federal Emergency Management Agency (FEMA), undertook a study of the Suncook River 2006 flood. A sedimentation model was created to aid State and local authorities in predicting sediment levels and riverbed stability and movement under various flow scenarios, and equally to assist future restoration efforts by furthering the understanding of the effect of sediment transport on the environment by use of data from an established streamgage in the study area.

The USGS streamgage 01089500, Suncook River at Depot Road in North Chichester, Merrimack County, New Hampshire (fig. 1) was active during 1919-20, 1922-27, and 1929-70 (only peak flow data were collected from 1971 through 1977). On November 9, 2007, the Suncook River streamgage was reactivated. On the basis of surveyed high-water marks, the peak flow for May 13-16, 2006, was determined to be the third highest flood (7,600 cubic feet per second $\left(\mathrm{ft}^{3} / \mathrm{s}\right)$ ) at the Suncook River streamgage (Olson, 2007). Less than a year after the 2006 breach, during April 16-18, 2007, southeastern New Hampshire experienced severe flooding due to a storm that stalled off the New England coast. The peak flow of April $2007\left(10,600 \mathrm{ft}^{3} / \mathrm{s}\right)$ was the second highest flood recorded at the Suncook River streamgage (Flynn, 2008). The highest flood of record at the Suncook River streamgage $\left(12,900 \mathrm{ft}^{3} / \mathrm{s}\right)$ occurred in March 1936.

The new channel through the abandoned sand pit has impacted the natural level of sediment induction into the river. Shortly after the breach, Chad Wittkop (New Hampshire Geological Survey, written commun., 2006) estimated that 150,000 cubic yards $\left(\mathrm{yd}^{3}\right)$ of sediment was introduced into the Suncook River as a result of the new channel path through the sand pit and adjacent wetlands. Following the May 2006 breach, layers of silt and sand as much as 5 feet (ft) thick were deposited downstream of the new avulsion (abandonment of a river channel and formation of a new river channel), potentially changing designated flood zones and increasing sediment loads. The transported sediment decreased overall channel depth downstream of the sand pit with a mean aggradation (net raising of the streambed) of $0.88 \mathrm{ft}$ between the Short Falls Road Bridge and the Buck Street Dams, leading to an increase in the elevation of the 50-, 10-, 2-, 1-, and 0.2 -percent annual exceedance-probability floods. In the avulsion area and upstream, downcutting of the stream continues (2011) to occur due to the river's increased gradient as a result of the reduction in river length and the convergence of flow from two river reaches into one. As the gradient increases, a higher erosion rate of the river's banks can be expected.

Quasi-unsteady-state flow approximates a continuous hydrograph with a series of discrete steady flow profiles (for example, sequential steady-state) (USACE, 2008c). For each record in the flow series, flow remains constant over a specified time window for transport (for example, mean daily flow is assumed for 24 hours) and, as in the case of the sedimenttransport model, bathymetry is updated. Steady-state flow refers to the condition where fluid properties at a point in the channel do not change over time.

Following verification of the steady-state flow model and of a 400-day quasi-unsteady-state calibration model for sediment transport, the response of the sediment-transport model was simulated from May 2008 (date of acquisition of channel cross-section data) through the end of water year (WY) 2010 (September 30, 2010). Based on Markov chain analyses, daily mean flow and water-temperature data at the Suncook River streamgage for WY 2009 were selected to represent daily mean flow and water temperature for WY 2010 in the model. The resulting quasi-unsteady-state streambed elevations, modeled through the end of WY 2010 to determine the effects of sediment aggradation and degradation on the streambed, were then imported into a steady-state HEC-RAS model to estimate changes to the 50-, 10-, 2- 1-, and 0.2-percent annual exceedence-probability (2-, 10-, 50-, 100-, and 500-year recurrence-interval, respectively) flood elevations as reported by Flynn (2010).

An understanding of sediment-transport characteristics is important for applications that include flow regime change, channel-restoration efforts, and predictions of the effects of land-use changes (Wilcock, 2001). In order to establish river equilibrium for river-corridor protection and restoration, knowledge of the relation between flow and sediment transport and an assessment of the ability of the existing channel to transport sediment is critical. The measurement of sediment load and particle size moving through a reach at various flows for development of sediment-discharge curves (curves showing the relation between streamflow and sediment discharge for a specific sediment-sampling site) is important for rivercorridor protection and restoration design. Once the conditions required for sediment transport are understood, a determination of the channel dimension, pattern, and profile required for sufficient transport of the expected sediment supply can be made (Vermont Agency of Natural Resources, 2009). 


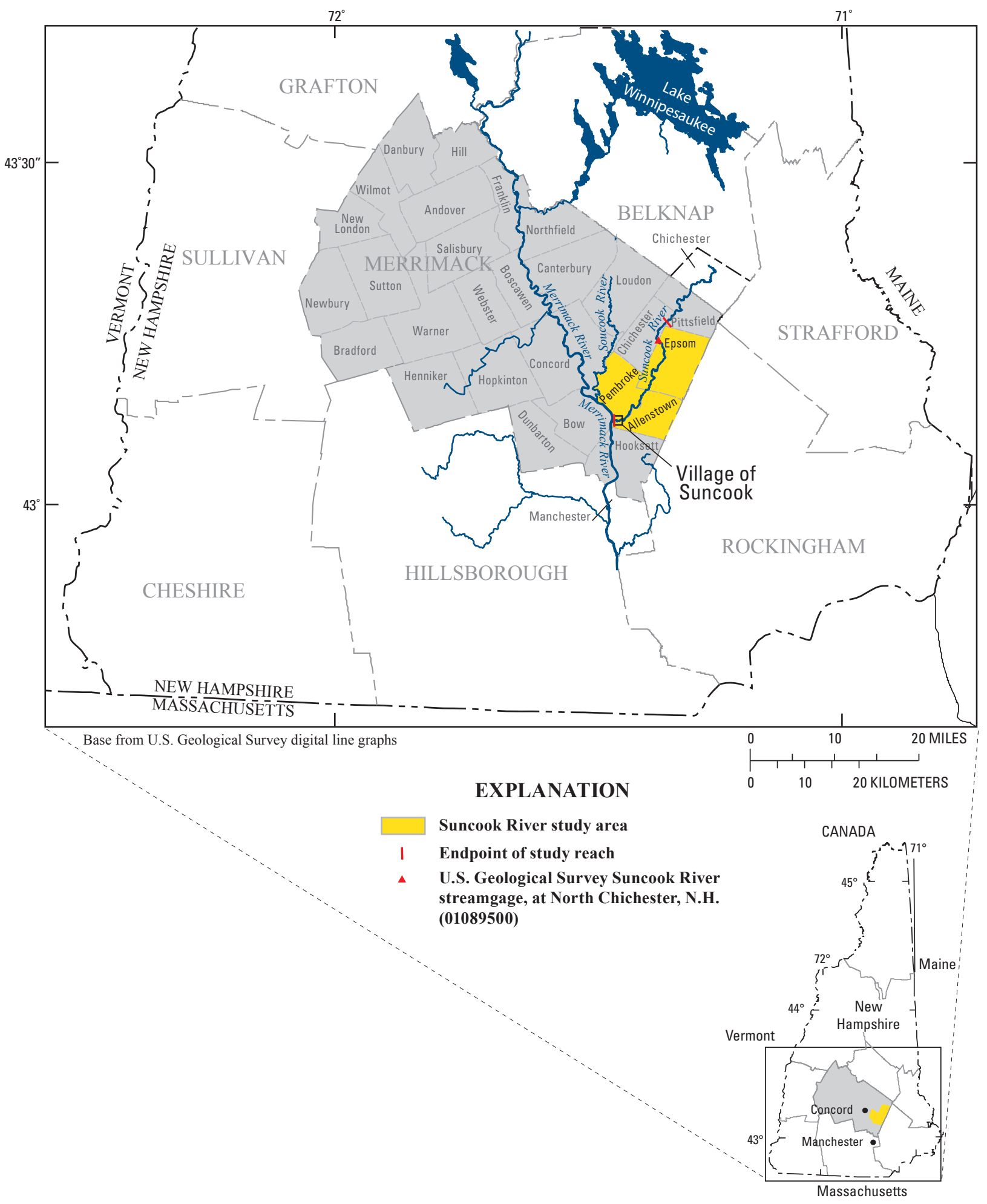

Figure 1. Extent of the sediment-transport study of the Suncook River in Epsom, Pembroke, and Allenstown, New Hampshire, 2009-10. 


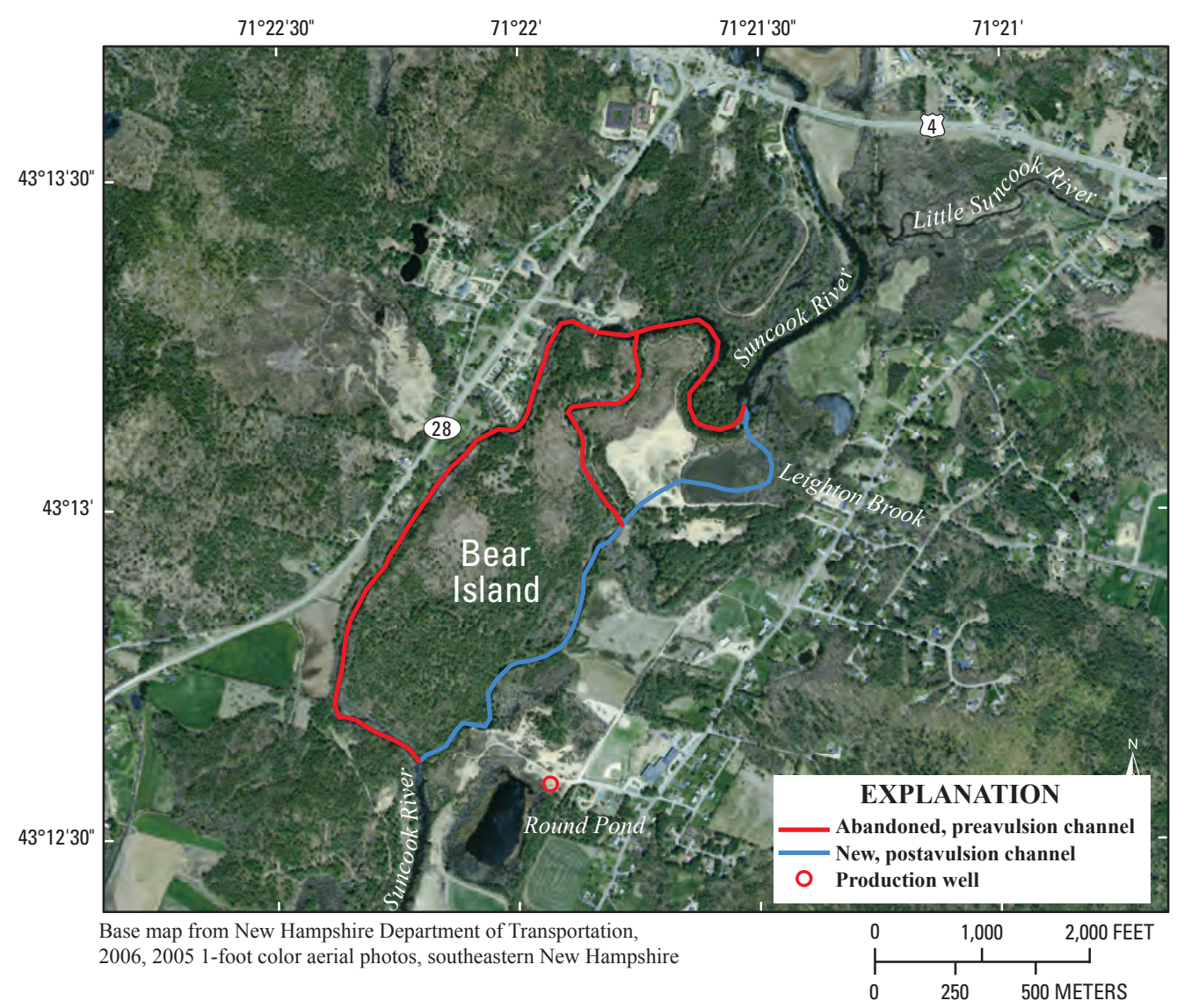

Figure 2. Preavulsion aerial imagery showing the new and abandoned channels resulting from the May 2006 Suncook River avulsion, Epsom, New Hampshire.

\section{Purpose and Scope}

This report describes the results of the study to assess sediment aggradation and degradation in the Suncook River; to quantify sediment loads for calibration of the sedimenttransport components of deposition and erosion, and of deposition in a quasi-unsteady-state sediment-transport HECRAS model; to study the effect of the stream avulsion on sediment transport; and to predict the impact of sediment on selected recurrence-interval floods in the Suncook River from its confluence with the Merrimack River in Allenstown to the upstream limit of Epsom, N.H. The report also describes the collection of suspended-, bedload-, and streambed-sediment samples to characterize sediment sources and transport under varied flow conditions and to provide information for determining the impact of sediment on property, infrastructure, flood elevations, and aquatic life and habitat.

This report documents the development and calibration of a one-dimensional sediment-transport model based on the Hydrologic Engineering Center-River Analysis System (HEC-RAS), version 4.0.0 (USACE, 2008a), which was used for a 15.9-mile (mi) reach of the Suncook River from its confluence with the Merrimack River to the upstream corporate limit of Epsom, N.H. This reach includes the location of the May 2006 avulsion. The steady-state HECRAS flow model that was used to develop a quasi-unsteadystate sediment-transport model to calibrate stream-channel cross sections and April 2007 high-water floodmark data (Flynn, 2010). The one-dimensional quasi-unsteady-state HEC-RAS sediment-transport model used in this study simulates a moveable streambed, calculates sediment transport, and averages sediment deposition or aggradation across all of the cross sections in the study reach.

\section{Previous Investigations}

Previous hydrologic and geomorphic studies of the Suncook River include a stream-restoration study for the Suncook River (Vanasse Hangen Brustlin (VHB) Inc., and others, 2008); a characterization of sediment wave-induced channel evolution in the river (Perignon, 2008); and a 2010 flood study of the reach (Flynn, 2010). Using HEC-RAS, Flynn (2010) modeled flood events of a magnitude that are 
expected to be equaled or exceeded once in the Suncook River (on average) during any 2-, 5-, 10-, 25-, 50-, 100-, or 500 -year period. These flood events, also referred to as the 2-, 5-,10-, 25-, 50-, 100-, and 500-year recurrence-interval floods, have 50-, 20-, 10-, 4-, 2-, 1-, and 0.2-percent probabilities, respectively, of being equaled or exceeded during any year. Previous flood studies were completed for the towns of Epsom, Pembroke, and Allenstown. A Flood Insurance Study (FIS) (January 1978) and a Flood Insurance Rate Map (FIRM) (July 3, 1978) were prepared for the town of Epsom (U.S. Department of Housing and Urban Development, Federal Insurance Administration, 1978b). FISs (October 1978) and FIRMs (April 2, 1979) were also prepared for the towns of Pembroke and Allenstown (U.S. Department of Housing and Urban Development, Federal Insurance Administration, 1978a and c).

\section{Description of Study Reach}

Originating south of Lake Winnipesaukee in Gilford, N.H., the Suncook River flows through the western portions of the towns of Epsom and Allenstown. State Route 28 (fig. 3B) runs parallel to the Suncook River and connects the towns of Chichester, Epsom, Pembroke, and Allenstown. The Suncook River is approximately $39 \mathrm{mi}$ long and flows in a southerly direction with a drainage area of 154 square miles $\left(\mathrm{mi}^{2}\right)$ at the USGS Suncook River streamgage 1089500 in North Chichester. At its confluence with the Merrimack River in the village of Suncook (in Allenstown and Pembroke), the Suncook River has a total drainage area of $256 \mathrm{mi}^{2}$.

The prevailing winds in Epsom, Pembroke, and Allenstown are from the northwest and result in cold, dry air in the winter and cool, dry air in the summer. Strong winds from the south occur in July and August, and winds from the east typically coincide with summer and winter storms (National Climate Data Center, 2008). Precipitation falls on an average of 1 day out of 3 during the year; the frequency is slightly higher for April and May and slightly lower for August to October. Snow cover typically lasts from midDecember until the last week of March, although bare ground is not a rarity in the winter. Rain, sleet, or freezing rain may also occur during the winter (National Climate Data Center, 2008).

The average daily maximum and minimum temperatures for July in Concord, N.H., are 82.2 and $57.2^{\circ} \mathrm{F}$, respectively. The average daily maximum and minimum temperatures for January in Concord are 31.1 and $10.7^{\circ} \mathrm{F}$, respectively. Average annual precipitation in Concord for 1979-2008 (rain, snow, and sleet) is $37.9 \mathrm{in}$. Average annual snowfall in Concord for 1979-2008 is 63.8 in. (National Climate Data Center, 2008).

The topography of Epsom, Pembroke, and Allenstown is hilly and characterized by stratified and unstratified material transported and deposited by retreating glacial ice. The flood plains adjacent to the rivers are composed of alluvial silt overlying glacial outwash. The predominant soil group is composed primarily of well-drained sandy loam in glacial till. Kames, terraces, deltas, and outwash plains are glacial landforms common to this area. Elevations range from $192 \mathrm{ft}$ (National Geodetic Vertical Datum of 1929) (NGVD 29)) at the confluence of the Suncook and Merrimack Rivers to $1,413 \mathrm{ft}$ (NGVD 29) at the summit of Fort Mountain in Epsom. Wetland areas throughout the three towns serve as the headwaters for many smaller streams.

In general, the flood plains along the Suncook and Little Suncook Rivers (fig. 2) are sparsely developed with the exception of areas near the intersection of the Suncook River and U.S. Route 4, the intersection of the Suncook River and U.S. Route 3, downstream through the village of Suncook, and near Epsom along the Little Suncook River. The Suncook River study area contains a mixed landuse of forested, agricultural and residential. Analysis of aerial photography from 1953 to 2003 showed an increase in the forested area surrounding the Suncook River (VHB, 2008). The population of the four towns in the study area increased between 2000 and 2009 with the greatest percent increase in population occurring in the northern study-area towns of Chichester and Epsom, where the population is smaller (table 1 ).

The Suncook River has no major flood-control structures. The Pittsfield Mill Dams in Pittsfield, N.H., Buck Street Dams in Pembroke, N.H., and Webster, Pembroke, and China Mill Dams in the village of Suncook are all run-of-river dams and do not act as flood-control dams. The Webster, Pembroke, and China Mill Dams are used for hydroelectric-power generation. These dams do little to attenuate major flood peaks.

The new channel through the former sand pit created by the breach of May 15, 2006, is approximately $0.42 \mathrm{mi}$ in length. The abandoned primary (eastern) channel is approximately $0.87 \mathrm{mi}$ in length, and the abandoned western channel is approximately $1.14 \mathrm{mi}$ in length, giving a total length for the abandoned channel (fig. 2) of $2.01 \mathrm{mi}$. The new channel from north of the Suncook River's former confluence with the abandoned channel (upstream of the avulsion), through the former sand pit, south into the east channel, and to the downstream location of the former confluence with the abandoned west channel (southern end of Bear Island) is $1.02 \mathrm{mi}(5,385 \mathrm{ft})$ in length. As a result of the reduction in total stream length from 2.01 to $1.02 \mathrm{mi}$, the river's average gradient has increased by approximately 40 percent between the upstream and the downstream locations of the abandoned channels. Based on 2008 thalwegs (deepest location in the channel) of the cross-section surveys (cross sections CM to DE) (fig. 4C), the streambed gradient is 14.0 feet per mile (ft/mi), whereas the average gradient of the abandoned east and west channels between these same locations was $10.0 \mathrm{ft} / \mathrm{mi}$ before the avulsion (U.S. Department of Housing and Urban Development, Federal Insurance Administration, 1978b). Because the channel is no longer split around Bear Island and is now shorter and steeper, the average velocity of the river has increased, which in turn will increase the river's capability to erode both vertically and laterally. 


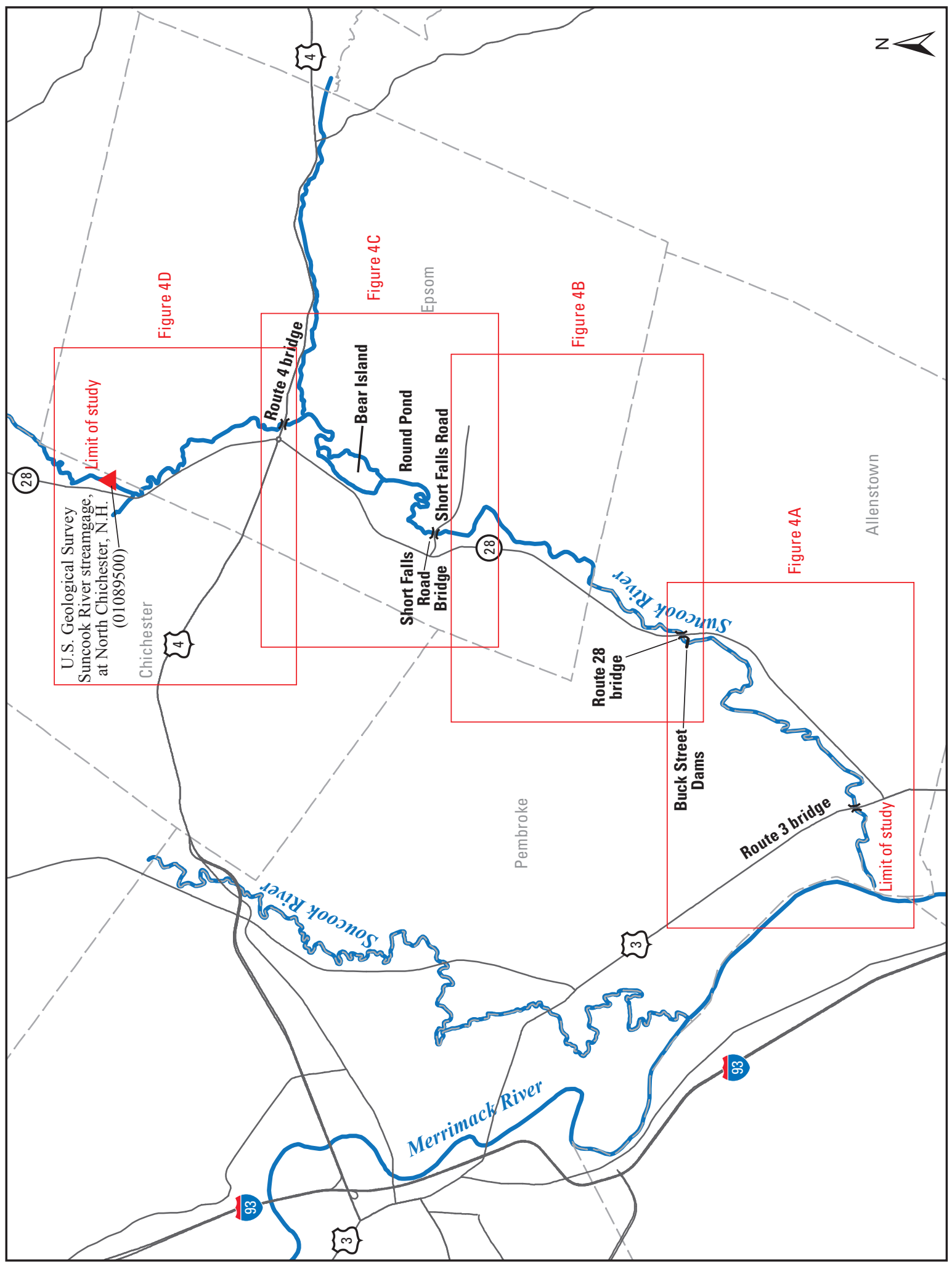

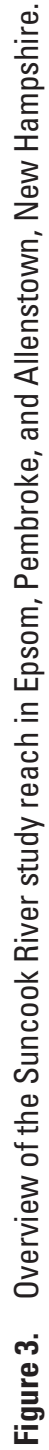


Table 1. Population information for the towns in the Suncook River study area.

[mi², square miles; Data from New Hampshire Employment Security, Economic and Labor Market Information Bureau]

\begin{tabular}{lccccc}
\hline Town & $\begin{array}{c}\text { Land area } \\
\left(\mathbf{m i}^{2}\right)\end{array}$ & $\begin{array}{c}\text { Inland water area } \\
\left(\mathbf{m i}^{2}\right)\end{array}$ & $\begin{array}{c}\text { Population } \\
(\mathbf{2 0 0 9 )}\end{array}$ & $\begin{array}{c}\text { Population per square } \\
\text { mile of land area }\end{array}$ & $\begin{array}{c}\text { Percent in population increase } \\
(\mathbf{2 0 0 0 - 2 0 0 9 )}\end{array}$ \\
\hline Allenstown & 20.5 & 0.1 & 4,957 & 247 & 2 \\
Chichester & 21.2 & 0.1 & 2,583 & 120 & 14 \\
Epsom & 34.5 & 0.1 & 4,609 & 135 & 14 \\
Pembroke & 22.6 & 0.2 & 7,344 & 325 & 6 \\
\hline
\end{tabular}

\section{Geohydrology of the Suncook River}

The study reach of the Suncook River has numerous oxbows in the flood plain that are remnants of the river's postglacial meanderings. Located in the Upper Merrimack River Basin, the study area is underlain by bedrock associated with the Central New Hampshire Anticlinorium (Lyons and others, 1986), a type of geological fold that is convex upward (anticline) with minor folds (anticline and syncline) superimposed. The anticlinorium trends in a north-northeast to south-southwest direction and contains metamorphic rocks of Devonian and Silurian age, including gneiss, schist, and quartzite. These metamorphic rocks were intruded by granite, granodiorite, syenite, and monzonite of Devonian age (Lyons and others, 1986). A fault line (Pinnacle Fault) extends northeast to southwest through Pittsfield and into Suncook and trends southwest into Massachusetts (Stekl and Flanagan, 1997).

The Suncook River flows through an area of fine- to coarse-grained stratified-drift deposits (Stekl and Flanagan, 1997). Four stratified-drift aquifers were identified along the study reach-Upper Suncook River Aquifer, Suncook and Round Pond Aquifer, Bear Brook Aquifer, and the Lower Suncook River Aquifer (Stekl and Flanagan, 1997). These aquifers are potentially significant sources of groundwater based on the following criteria: generally composed of wellsorted sand and gravel; saturated thickness (volume of aquifer in which pore spaces are completely filled with water) of sand and gravel equal to or greater than $40 \mathrm{ft}$; and surface areas equal to or greater than $0.2 \mathrm{mi}^{2}$.

The Upper Suncook River Aquifer (fig. 4D), with a surface area of approximately $1.1 \mathrm{mi}^{2}$, lies primarily in the northwestern part of Epsom. It is composed of a heterogeneous mix of coarse sand and gravel deposits that are underlain and intermixed with fine-grained lake-bottom deposits. Discontinuous beds of clay and silt are present throughout the aquifer, and the streambanks contain a highly varied stratigraphy of alluvium, lake-bottom clay, and stratified-drift deposits. The saturated thickness of the stratified drift is approximately $40 \mathrm{ft}$ throughout much of the aquifer and approximately $60 \mathrm{ft}$ in the center (Stekl and Flanagan, 1997).
On the upstream opening of the Route 4 bridge over the Suncook River on the northeast overbank of the western, primary channel, a lithologic log of well ESW10 (unnamed owner) (figs. $4 \mathrm{C}$ and D), which is at longitude $71^{\circ} 21^{\prime} 25^{\prime \prime} \mathrm{W}$ and latitude $43^{\circ} 13^{\prime} 37^{\prime \prime} \mathrm{N}$, indicates bedrock at altitude $305 \mathrm{ft}$ ( $+5 \mathrm{ft}, \mathrm{NGVD} 29$ ). According to the well log, the material into which the well was placed in 1990 is predominantly fine to coarse sand (Stekl and Flanagan, 1997). Auger-drilling refusal was found at $35 \mathrm{ft}$ below the land surface (Stekl and Flanagan, 1997), possibly indicating the top of a consolidated layer. Cross-section surveys (Flynn, 2010) determined that the altitude of the thalweg of the Suncook River at the approximate location of well ESW10 is $329.8 \mathrm{ft}$ (NGVD 29), indicating a sand layer of approximate thickness $24.8 \mathrm{ft}(+5 \mathrm{ft})$ beneath the channel at this location. A headcut has formed on the Suncook River (fig. 4C, approximate location at cross section DG) as a consequence of the avulsion that created a new shorter but steeper channel downstream of the avulsion. A headcut is an abrupt downward change in the elevation of the streambed. Water flowing over the headcut causes erosion on the face of the overfall area, gradually moving the headcut upstream.

The Suncook River and Round Pond Aquifer (fig. 4C), which has a surface area of approximately $1.5 \mathrm{mi}^{2}$, lies south of the Upper Suncook River Aquifer, trending northeast to southwest, beginning east of the southern tip of Bear Island and extending $1.3 \mathrm{mi}$ to the southwest. This aquifer is bounded to the north and south by relatively impermeable very fine sand, silt, and clay lake-bottom deposits. A deep bedrock trough extending south of Bear Island contains a layer of as much as $65 \mathrm{ft}$ of medium to coarse sand and gravel deposits overlying a thick layer of fine sand and silt deposits, with finegrained deposits typically found outside of the channel. The saturated thickness of the material in the bedrock trough is greater than $120 \mathrm{ft}$ in places (Stekl and Flanagan, 1997).

Near the former sand pit, a study of stratified-drift aquifers in the upper Merrimack River Basin (Stekl and Flanagan, 1997) included a lithologic log of well ESW6 (fig. 4C), which is located at longitude $71^{\circ} 21^{\prime} 48^{\prime \prime} \mathrm{W}$ and latitude $43^{\circ} 12^{\prime} 58^{\prime \prime} \mathrm{N}$ on the eastern overbank of the Suncook River. According to the well log, the material into which the well was placed in 1989 is predominantly fine sand with some 


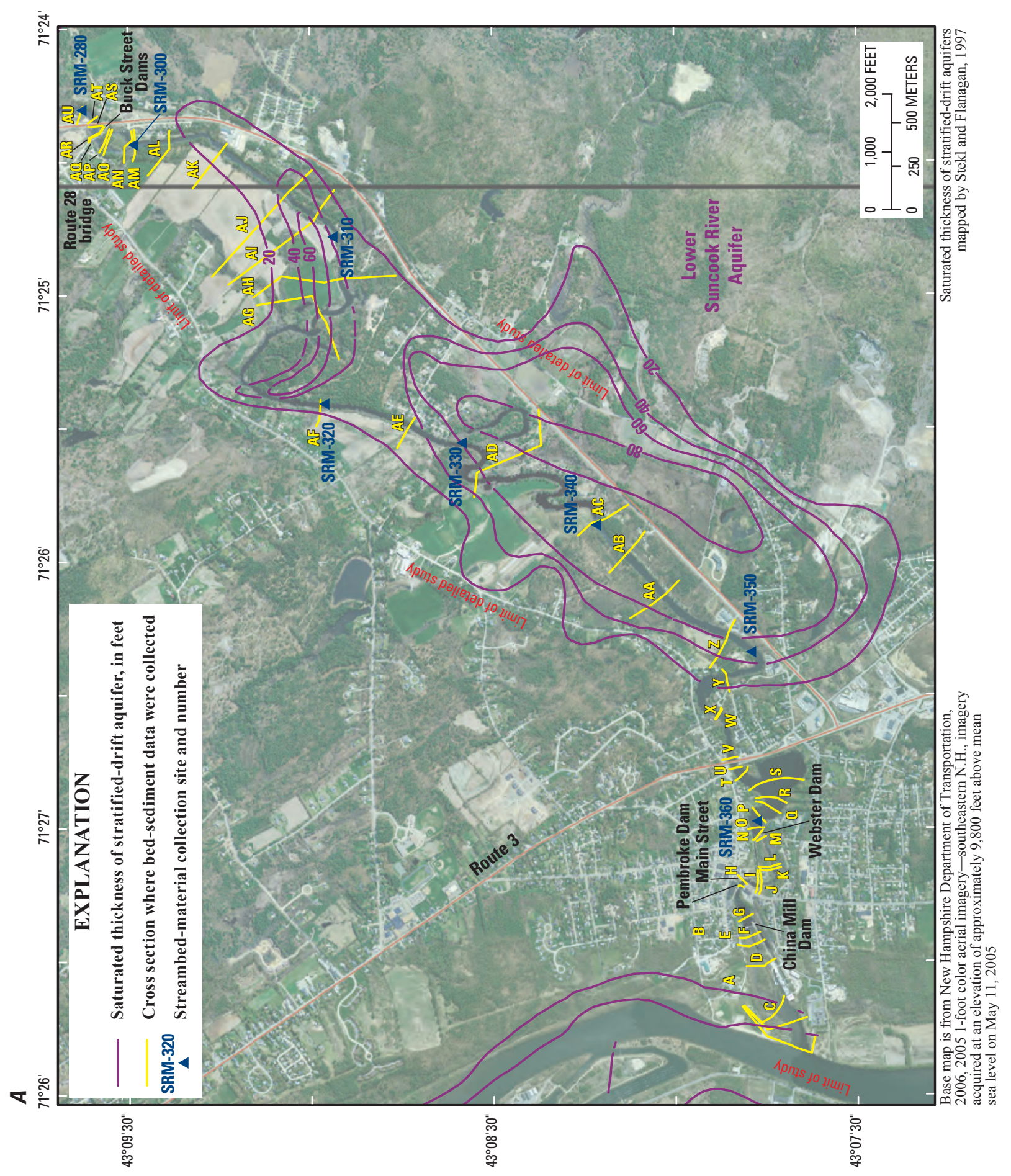

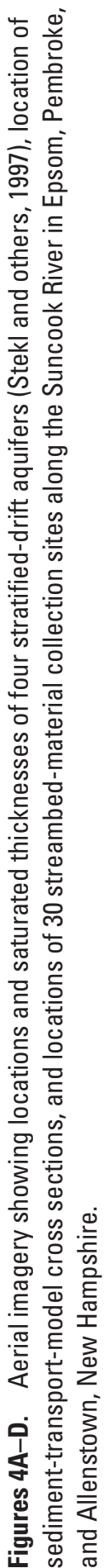




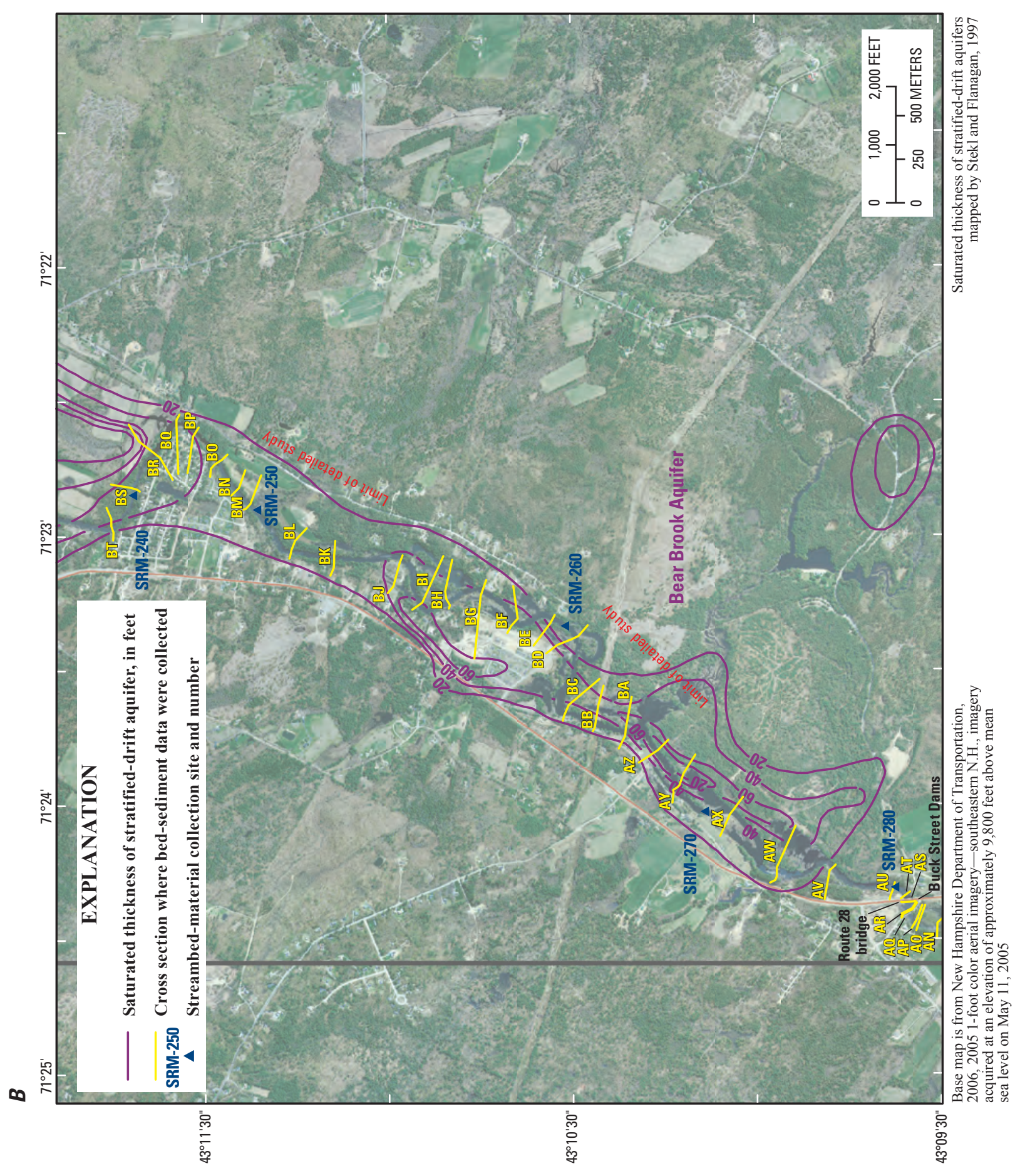

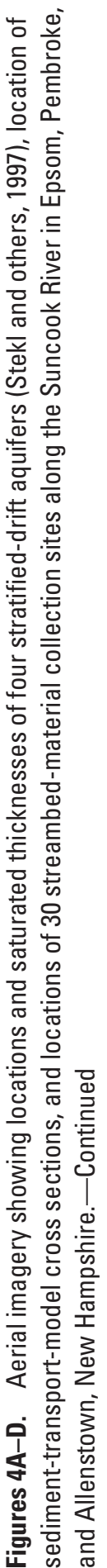




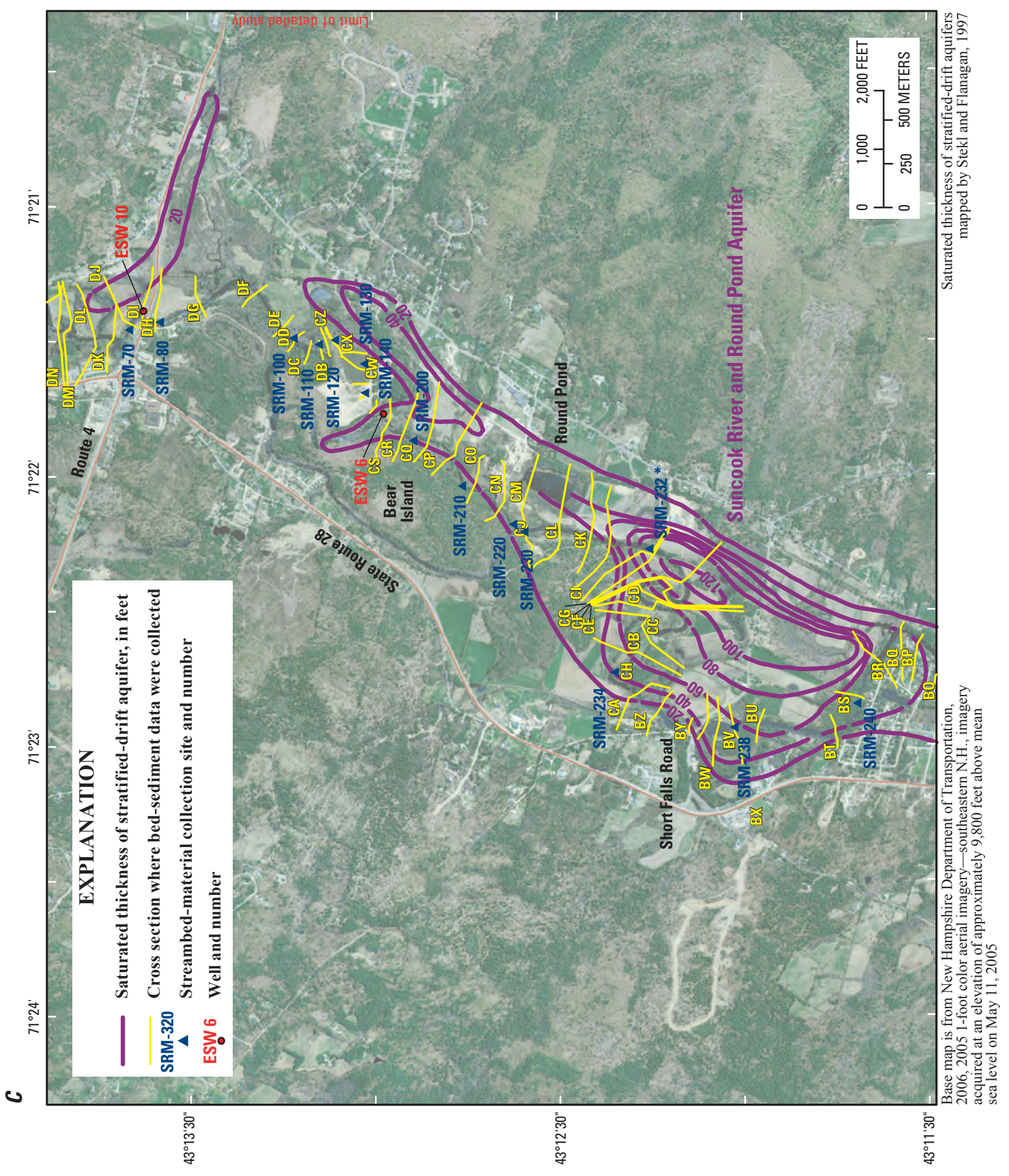

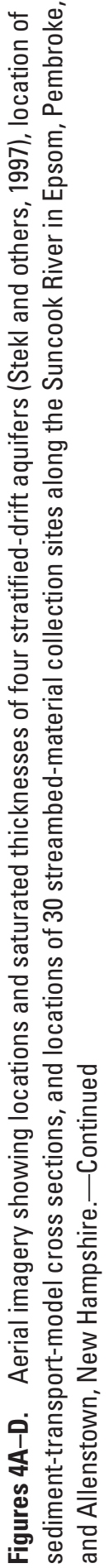




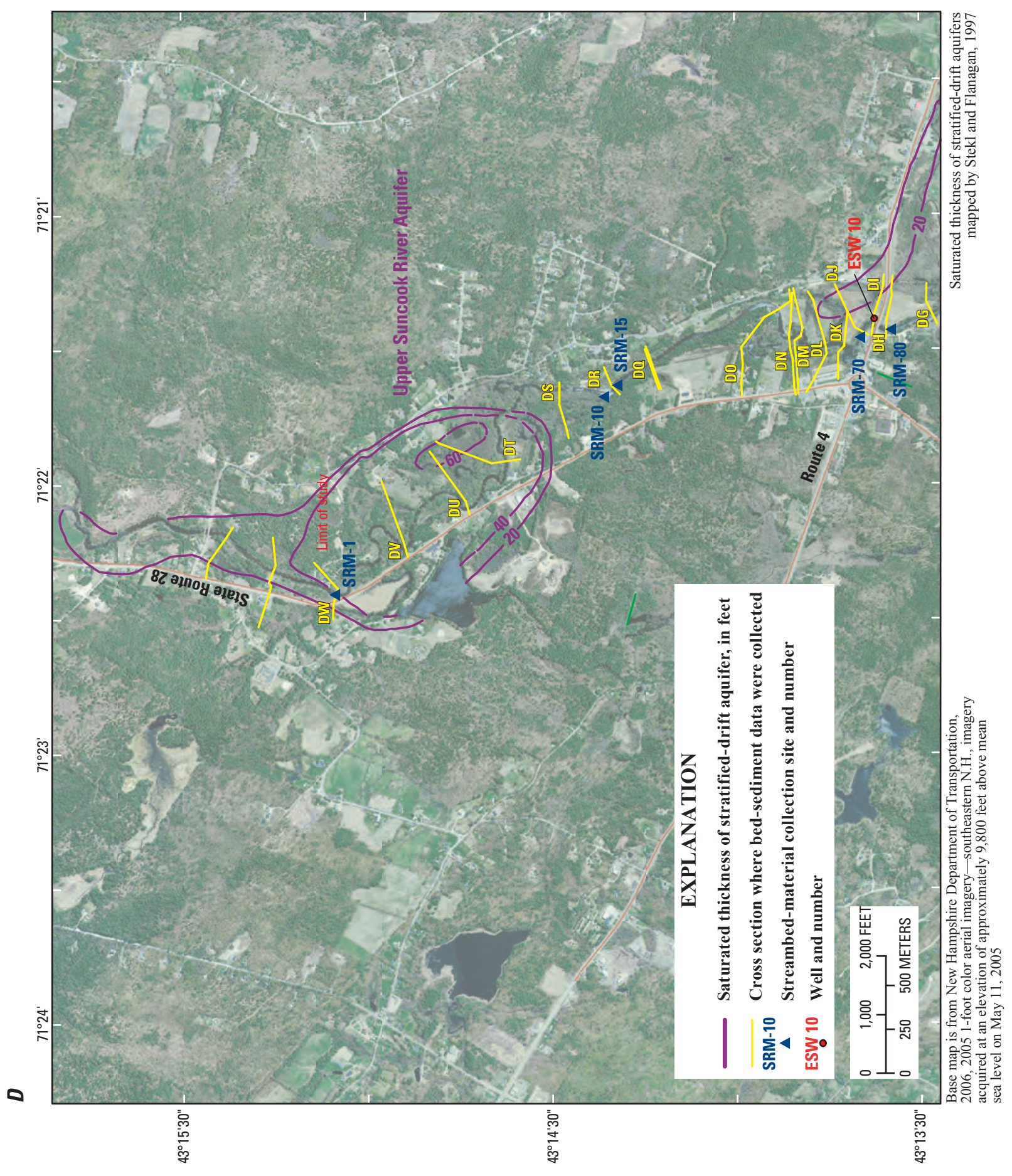

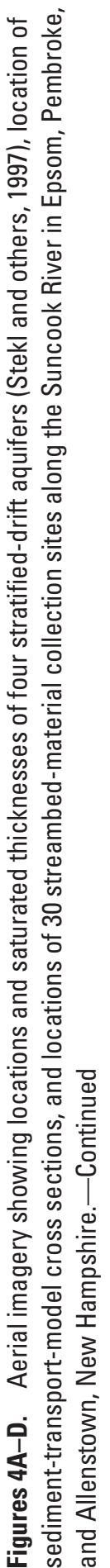


coarse material (sand and gravel) between 7 and $15 \mathrm{ft}$ below the top of the well. Refusal was found at $39 \mathrm{ft}$ below the land surface (Stekl and Flanagan, 1997), possibly indicating the top of a consolidated layer. A geohydrologic section interpreted from seismic-refraction data as extending approximately $530 \mathrm{ft}$ northwest from well ESW6 indicates bedrock at $265 \mathrm{ft}(+5 \mathrm{ft}, \mathrm{NGVD} 29)$ at well ESW6, with a bedrock elevation of $285 \mathrm{ft}(+5 \mathrm{ft}$, NGVD 29) $530 \mathrm{ft}$ northwest of well ESW6. Cross-section surveys (Flynn, 2010) determined that the thalweg of the Suncook River, at the approximate location of ESW6, is at an altitude of approximately $301.5 \mathrm{ft}$ (NGVD 29), indicating a sand layer extending approximately $36.5 \mathrm{ft}$ $(+5 \mathrm{ft})$ beneath the channel at this location.

The Bear Brook Aquifer (fig. 4B), which has a surface area of approximately $1.7 \mathrm{mi}^{2}$, lies south of the Suncook River and Round Pond Aquifer. It is at the confluence of Bear Brook and the Suncook River and trends northeast to southwest. The sediments in the bedrock channel are primarily coarse sand and gravel deposits. The stratified-drift sediments are predominantly sand, silt, and clay lake-bottom deposits. Saturated thickness of the stratified drift is $65 \mathrm{ft}$ at the Suncook River, with a maximum of $81 \mathrm{ft}$ and a minimum of $19 \mathrm{ft}$ east of the Suncook River (Stekl and Flanagan, 1997).

The Lower Suncook River Aquifer (fig. 4A), which has a surface area of approximately $0.9 \mathrm{mi}^{2}$, lies south of the Bear Brook Aquifer. It is in east Pembroke and trends east-northeast to west-southwest. The aquifer contains coarse-grained deltaic deposits overlying fine-grained lake-bottom deposits. Near Route 28 east of the Suncook River, the aquifer consists primarily of coarse sand and gravel deposits with a saturated thickness of less than $20 \mathrm{ft}$. The average saturated thickness of the aquifer is $33 \mathrm{ft}$ (Stekl and Flanagan, 1997).

\section{Characterizing Sediment Transport and the River Streambed}

Sediment transport is defined as the conveyance of sediment by flowing water that is initiated when the threshold for movement has been exceeded. Although sediment transport is closely tied to known factors, including water flow, energy, and sediment source, understanding the movement of river sediment can be difficult because sediment transport has a transient nature. However, with a proper sampling and assessment program, sediment transport can be quantified. Sediment transport may vary significantly from the initial flush of a storm to the time of peak flow in the watershed with respect to total sediment load (suspended load plus bedload) and distribution of particle size.

Sediment in streams can adversely affect water quality and aquatic life and habitats, and it may present a hazard to downstream infrastructure and residents. Suspended fine sediments reduce the clarity of the water and possibly also biologic productivity, but the suspended sediments can also carry nutrients that may increase biological productivity. Coarse suspended sediments can bury stream habitats and can diminish the overall abundance and diversity of species.

A catastrophic event, such as the avulsion that occurred on the Suncook River in May 2006, significantly changes the slope and shape of the sediment-discharge curve. This curve can be used to estimate sediment concentration when data on water discharge, but not on sediment, are available. Because the Suncook River is still adjusting to attain equilibrium, the sediment-transport curve will continue to change. Some of the other parameters that can affect the slope and shape of sediment-discharge curves are seasons, timing of sediment peaks versus flow-discharge peaks, and extreme high-water or sediment-load events (Glysson, 1987). Although this relation is referred to as a sediment-discharge curve, the phrase is not descriptive, as it implies a cause-and-effect relation between discharge and sediment and a specific value of sediment concentration for each discrete value of streamflow (Glysson, 1987). Colby (1964) states that "at a cross section of a stream, the sediment discharge may be considered to depend on depth, width, velocity, energy gradient, temperature, and turbulence of the flowing water; on size, density, shape, and cohesiveness of particles in the banks and beds at the cross-section and upstream channels; and on the geology, meteorology, topography, soils, subsoils, and vegetal cover of the drainage area." In alluvial streams, such as the Suncook River, sedimentdischarge curves typically exhibit a wide scattering of the data, a circumstance that should not be interpreted simply as sample error. The range in scatter between high and low data is more accurately attributed to aggradation, degradation, changing bedforms in the stream channel, or sediment-transport rates affected by variation in water temperature (Thomas, 1977). In addition, for a given flow rate on either side of the flood peak, the quantity of suspended material over the course of a flood peak completes a hysteresis loop, being considerably larger at the rising water stage is than at the falling stage (American Society of Civil Engineers (ASCE, 2008)).

Hydrologic, geologic, geographic, and biologic factors affect the sediment load of a stream. Season, snowmelt, duration and intensity of rainstorms, watershed use, vegetation cover, watershed field slope, soil types, and human and animal activities further determine the amount of sediment entering and transported by the stream (ASCE, 2008). Seasons can have a significant effect on the natural level of sediment induction into a stream. During the winter, the ground may be frozen, and precipitation may be in the form of snow. The absence of the impact of raindrops to loosen the soil and frozen ground holding the soil together are factors in transporting less sediment. During the summer, the impact of raindrops from high-intensity storms results in high concentrations and transport loads of sediment. Areas along the river that are used for agricultural purpose can further contribute to sediment loads. The fields are bare in winter and spring but, as the crops emerge, plant growth protects the soil from erosion. In these cases, sediment concentrations and loads for a given discharge may be low in the winter (frozen ground) and in summer 
(rooted crops) but high in the spring (before planting and growth of crops) and in fall (after harvest) (Glysson, 1987).

The driving force for sediment transport is the shear stress $\left(\tau_{0}\right.$, eqn. 1$)$ exerted on the channel boundary by flowing water, which is a measure of the stream's ability to entrain bed material. The mean boundary shear stress in a channel can be expressed as

$$
\tau_{0}=\gamma D S,
$$

where

$$
\begin{gathered}
\tau_{0} \quad \begin{array}{c}
\text { is the mean boundary shear stress, in pounds } \\
\text { per square foot; }
\end{array} \\
\gamma \quad \text { is the specific weight of water, in pounds per } \\
\text { cubic foot; } \\
D \quad \text { is the mean flow depth, in feet; and } \\
S \quad \text { is the energy gradient or slope of the water } \\
\text { surface, in foot per foot. }
\end{gathered}
$$

Boundary shear stress $\left(\tau_{0}\right)$ is dependent on flow depth, which is influenced by river discharge. In alluvial rivers, deposition (which occurs where shear stress is decreasing) and erosion (which occurs where shear stress is increasing) follow shear stress. Whether aggradation or deposition occurs also depends on the concentration of particles in suspension in the reach (Berenbrock and others, 2005).

Sediment movement (entrainment) in a stream is in part a function of the boundary shear stress $\left(\tau_{0}\right)$ that is created by flowing water acting on sediment particles. The entrainment potential is estimated from the relation between a floodgenerated shear stress and the critical shear stress $\left(\tau_{\mathrm{c}}\right)$, that is, the shear stress at which sediment particles begin to move. Critical shear stress has been related to characteristics of sediment size. Many studies have used the Shields (1936) equation (eqn. 2) to estimate the critical shear stress for entrainment of the median grain size of sediment (referred to as the $\left.d_{50}\right)$ :

$$
\tau_{\mathrm{c}}=\tau_{\mathrm{c}}^{*}\left(\gamma_{\mathrm{s}}-\gamma\right) d_{50,}
$$

where

$$
\begin{aligned}
& \tau_{\mathrm{c}} \quad \text { is the critical shear stress, in pounds per } \\
& \tau_{c}^{*} \quad \text { is the dimensionless critical shear stress or } \\
& \text { Shields parameter; } \\
& \gamma_{\mathrm{s}} \quad \text { is the specific weight of sediment (assumed to } \\
& \text { be } 2.65 \text { times the specific weight of water); } \\
& \gamma \quad \text { is the specific weight of water; and } \\
& d_{50} \quad \text { is the median sediment particle size. }
\end{aligned}
$$

The mean boundary shear stress is related to the flow depth and water-surface slope, and so it also varies with increasing or decreasing discharge. In comparing the boundary shear stress $\left(\tau_{0}\right)$ for a particular discharge with critical shear stress $\left(\tau_{c}\right)$, it is possible to evaluate the sediment entrainment potential for that discharge with respect to the streambed.
Streamflows that generate a boundary shear in excess of the critical shear will initiate the movement of bed material. Over a period of time, and if the excess shear stress is great enough, it will result in bedload transport and, possibly, in channel adjustments leading to channel degradation. When the shear stress is less than critical shear stress, channel aggradation will likely occur, and when shear stress equals critical shear stress, channel equilibrium will likely occur.

Streambed material is defined as the mixture of sediment of which the bed is composed (Edwards and Glysson, 1999). It is sediment in the streambed that is at rest but that may resuspend and move as coarse suspended sediment or as bedload. The mechanisms by which it moves are various and complex. Bed material may include grain sizes that travel both as bedload and as suspended load (ASCE, 2008). Bed-material data were collected for creating sediment-gradation curves in the model to describe the variation of particle sizes in the sediment mixture. Sediment-gradation curves indicate the percentage of sediment passing through a particular sieve mesh size.

Total sediment discharge is defined as the sum of the suspended-sediment discharge and the bedload-sediment discharge. Finer material is typically carried in suspension, while larger particles tend to roll, slide, or bounce along the streambed. Suspended sediment is defined as that part of the total sediment load that is carried in the water column. It has also been described as sediment that is carried in suspension in the flow of a stream for appreciable lengths of time, being kept in this state by the upward components of flow turbulence or by Brownian motion (ASTM D 4411-03, 2004, and Thomas, 1977). Bedload sediment is defined as that part of the total sediment that is carried along the bottom by the tractive force of the moving water (Federal Interagency Sedimentation Project (FISP), 1941) intermittently to almost continuously in contact with the streambed by rolling, sliding, and bouncing (USEPA, 2008b; Thomas, 1977). It is sometimes part of the flow a few diameters above the bed. Bedload usually contributes only a small portion of total sediment discharge (Thomas, 1977) — 5 to 15 percent of a stream's total sediment load (USACE, 1993).

Wash load is defined as sediment carried by, and remaining near the top of, flow in the water column, moving with the mean velocity of the stream, and commonly considered to be the silt and clay fraction of the bed sediment (ASCE, 2008). For fine sediments that are nearly uniformly distributed over the depth of flow and that make up the wash load, the concentrations of sediment in the lower-to-middle parts of flow that move at a large fraction of the mean streamflow velocity (the suspended load) are essentially equal to the concentrations of total sediment discharge.

\section{Channel Equilibrium}

The geomorphic role of a river is to transport flow and sediment without aggrading or degrading the channel while maintaining its dimension, pattern, and profile. Instability of the stream channel is often associated with an excess load and 
(or) size of delivered sediment that is beyond the carrying capacity of the river, thus leading to aggradation, a condition that is occurring downstream of the Suncook River avulsion. If streambanks are unstable - a condition that can be seen in reaches both upstream and downstream of the Suncook River avulsion - the ratio of width to depth will increase, and slope and pattern of the river will change. Shear stress is proportional to the square of streamflow velocity and is defined as the force that is applied by a fluid parallel or tangential to the face of a material: stream power is defined as the rate of energy dissipation at a given point in a river system and is a function of streamflow, water density, acceleration due to gravity, and channel slope. Stream power (a product of specific weight of water, discharge, and energy slope) is inherently linked to sediment-transport competency-the ability of the stream to perform geomorphic work - channel stability, and sensitivity of the channel to high-magnitude flood events; it is also linked to flood-plain formation and to channel planform (the contour of the channel as viewed from above) (Reinfelds and others, 2003). The corresponding reduction in shear stress and stream power due to the change in the distribution of energy that results from a higher ratio of width to depth will lead to a decrease in the river's depth, velocity, and slope. For example, unless unstable Suncook River streambanks are stabilized, these channel and hydraulic changes will ultimately decrease the river's sediment competency and capacity for transporting and will lead to excess deposition of sediment (USEPA, 2008c).

Channels are formed, maintained, and altered by the water and sediment that they carry. For channels such as that of the Suncook River, with noncohesive sediments, Lane's relationship (1955) can be used to qualitatively predict channel conditions that will be erosive. Lane's stream-balance equation is useful for making qualitative predictions concerning impacts on a channel due to changes in runoff or in sediment loads. Quantitative predictions, however, require more complex calculations. Lane showed that channel equilibrium involved the interplay of four factors: sediment discharge $(Q s)$, median bed-sediment particle size $\left(d_{50}\right)$, streamflow $(Q w)$, and stream slope $(S)$, where $Q s * d_{50}$ is proportional to $Q w * S$. In the case of the reach below the avulsion-in particular, in the reach from upstream to downstream of Bear Island - streamflow $(Q w)$ remains the same while the median sediment particle size $\left(d_{50}\right)$ of the streambed decreased in the new channel (as compared to that in the abandoned channel), and the channel slope $(S)$ has increased dramatically. Accordingly, sediment discharge $(Q s)$ must increase. The resulting headcut, which "mines" the channel, supplies the sediment load as required for equilibrium. Various mechanisms may reduce or arrest the magnitude of the headcut degradation. A rock outcrop across the stream or development of an armor layer will stabilize the bed. Often, the hydraulic conditions downstream from the degrading reach will change because of a downstream aggradation condition, and these hydraulic changes will extend upstream.
A streambed can be in equilibrium because the material is being removed as rapidly as it is deposited (Thomas, 1977). Channel equilibrium occurs when all four of the variables detailed by Lane 1955) are in balance. If one variable changes, then one or more of the other variables must increase or decrease proportionally to maintain equilibrium. For example, if the channel slope is increased in a reach and streamflow remains the same (as is the case for the Suncook River avulsion reach), either the sediment load or the median bed-sediment particle size must also increase. The stream will also seek a new equilibrium by tending to erode more of its banks and its bed, resulting in transporting larger particle sizes and a greater sediment load. If excess energy remains after the load is moved, channel adjustment occurs as the stream picks up more load through erosion of its banks or through scouring of the streambed. Channel adjustment is occurring in the reach upstream of the avulsion, where degradation of the streambed has resulted in a headcut that is moving upstream toward the Route 4 bridge. In time, the erosion of bed sediments decreases as the slope is reduced through degradation of the streambed.

Although the new channel below the avulsion consists primarily of sand and silt, the reaches of the abandoned channel contain more coarse sediment. As the channel actively adjusts toward equilibrium, it will continue to adjust until (a) sufficient conveyance of sediment is reduced and (b) erosive forces on the banks decrease sufficiently such that a new flood-plain terrace develops. This evolution could take many decades.

\section{Stream Temperature}

Stream-temperature data are important in sediment transport because a change of a few degrees in water temperature will affect viscosity, which in turn can create a large difference in sediment-transport capacity. Cold water has a higher viscosity than warm water, resulting in an increased ability to transport sediment. In addition, colder water temperatures can cause the streambed to change from dunes to plane bedform. The fall velocity of sediment also decreases as stream temperature decreases; a decrease in water temperature will therefore cause the concentration of suspended sediment to tend toward uniformity. According to the Rouse equation (Rouse, 1937), the concentration of suspended sediment will tend to become more uniform over the depth of a flow as the fall velocity of the sediment decreases (ASCE, 2006). Assuming that the sediment concentration near the streambed, and the velocity and bed shear stress, do not change with stream temperature, the Rouse equation shows that the discharge of suspended sediment will tend to increase as stream temperature falls (ASCE, 2006). Studies have shown that the Manning's roughness coefficient, $n$, will decrease and that velocities will increase (Colby and others, 1965; ASCE, 2006) as discharge of the suspended sediment increases with decreasing stream temperature. 


\section{Bankfull Flow as Effective Discharge}

The flow that fills the active channel and begins to spread onto the flood plain represents the break between channel processes and flood-plain processes. This flow is assumed to equal the dominant or effective discharge, which is defined as the discharge that transports the largest fraction of the sediment load during a specific period of time. Although extreme fluvial events can heavily erode and enlarge stream channels, steeply incising them, more modest flow regimes transport the greatest quantity of sediment material over time because modest flows occur with higher frequency (Wolman and Miller, 1960). The effective discharge incorporates the principle that the channel-forming discharge is a function of both the magnitude of the event and the frequency of occurrence (Wolman and Miller, 1960).

For stable alluvial streams such as the Suncook River prior to the avulsion, the effective discharge has been shown to be highly correlated with bankfull discharge (USEPA, 2008a). Bankfull discharge is the streamflow that is associated with a momentary maximum flow; it is found to govern channel shape and form. Bankfull stage is identified from geomorphic features in the field. The effective or bankfull discharge represents the single flow that is responsible for transporting the most sediment during a period of time in which channel maintenance is the most effective, resulting in the average morphological characteristics of the channel. However, a range of flows on either side of the effective discharge also carry a significant amount of the total annual sediment load.

\section{Aggradation and Degradation}

Aggradation and degradation generally refer to trends in the profile of the streambed. An aggrading reach is one that is depositing more material than it is removing (or eroding). This condition persists when the sediment load exceeds the transport capacity of the channel-flow hydraulics; it is then said to be "depositional," elevating the streambed and potentially the flood plain, with the bed profile tending to become steeper (Thomas, 1977). The ratio of stream width to depth increases, and channel capacity decreases correspondingly. Overbank flows tend to occur more frequently with low recurrence-interval floods. Adverse consequences associated with aggradation include channel avulsion(s) along with change in the evolution of stream type. The supply of sediment and its adverse effects can be high during these adjustments of the channel - fish habitat may decline, stream temperatures may become elevated, and biological function may decline (USEPA, 2008e). In streams having fine sediment with noncohesive bed and banks, such as the Suncook River, a tendency to meander is associated with the aggrading reach. Because flow passing through an aggrading reach causes hydraulic sorting of sediment, with fine sediment dominating in the flow leaving the downstream end of the reach, the aggrading reach thereafter provides a temporary stopping place for sediment material moving downstream. A shift in the downstream streambed control point due to a degradation condition may stop aggradation (Thomas, 1977).

A degrading reach is defined as one that projects a net lowering of bed elevations, with the bed profile tending to become flatter over time (Thomas, 1977). This condition persists when the capacity of the river to transport sediment exceeds sediment supply; the river then picks up material stored in the channel and banks, resulting in a degradational trend or lateral erosion. The erosion of the streambed lowers the stage for a given flow, increases bank height, and causes the flood plain to be abandoned. As can be seen in the Suncook River study reach upstream of the avulsion, degradation of the stream reach as a result of excess shear stress due to changes in flow regime (USEPA, 2008d) can cause a headward advancement of the headcut. Although the degradation upstream of the avulsion is a result of the steeper channel and of excess shear stress following the avulsion, causes of degradation of a streambed reach are complex and can be attributed to many sources.

Over time, the streambed material will coarsen (sediment-size distribution will shift to larger particles) in the Suncook River. Vanoni (ASCE, 2006) stated that, because the bed-sediment load of streams is finer than the bed sediment from which it derives, we may conclude that the streambed will coarsen as the stream degrades. Conversely, the fact that beds of degrading streams do coarsen may be taken as evidence that the load is finer grained than the bed sediment. The prolonged degradation and coarsening of the bed sediment can lead to armoring of the bed and a drastic reduction in the rate of degradation and sediment discharge (ASCE, 2006).

Degradation is the dominant process for adjustment in the Suncook River channel at and above the avulsion site. Severe degradation of greater than $14 \mathrm{ft}$ occurred at the location of the May 2006 avulsion of the Suncook River, and an active headcut moved upstream to an area above the confluence of the river with the Little Suncook River (fig. 2). Downstream of the former sand pit, aggradation is the dominant process of channel adjustment. Major aggradation has occurred above and below Round Pond, in the area adjacent to the production well (fig. 2) and, in particular, in the reach between the former sand pit and the Buck Street Dams (figs. 4A and B).

\section{Methods of Analyses}

In order to characterize flow and sediment transport in the Suncook River following the May 2006 avulsion, the study collected cross-section elevation and streambed-sediment data in the channel and on the overbanks throughout the study reach (fig. 4). These data were then used to construct a onedimensional HEC-RAS sediment-transport model (USACE, 2008a) that estimated sediment transport, degradation, and aggradation along the river. A quasi-unsteady-state flow model was then run for the simulated WY 2010. The resultant cross 
sections were imported into a steady-state flow model, which was then run to determine the effects of the altered channel bed on flood elevations for the 50-, 10-, 2-, 1-, and 0.2-percent annual exceedence-probability floods.

\section{Channel-Geometry Data}

River cross sections were obtained from field surveys conducted during the summer of 2008. Valley and belowwater portions of the cross-section data were obtained from field measurements (using Acoustic Doppler Current Profiler (ADCP) and a surveying total station with level loop) that were referenced to the NGVD 29. Additional valley crosssection data were obtained using contour-interval data created from aerial photogrammetry collected in May 2007 (Eastern Topographics, 2007) and in April 2008 (Eastern Topographics, 2008). All bridges, dams, and culverts in the study reach were field-surveyed to obtain elevation data and structural geometry. Bridge, dam, and culvert cross-section data were collected at close intervals upstream and downstream of bridges and dams in order to compute the potential backwater effects of these structures. Over 150 cross sections (of channel and of structure) were surveyed in 2008 to define cross-section geometry for a flood study (Flynn, 2010) and for this sedimenttransport study.

Field-surveyed cross sections and flagged flood highwater marks from the April 2007 flood (Flynn, 2008) that had been used in calibrating the Suncook steady-state flow model (Flynn, 2010) were referenced to NGVD 29, in feet, using closed level-loop surveying methods from either a known reference datum or from a reference datum established using Leica System 1200 Global Positioning System (GPS) with 3-millimeter $(\mathrm{mm})(0.01-\mathrm{ft})$ horizontal accuracy and 10-mm $(0.03-\mathrm{ft})$ vertical accuracy in static mode (Leica Geosystems, 2008). Between the Short Falls Road Bridge and the Buck Street Dams, cross-section and profile data were also collected using a GPS in conjunction with an ADCP based on techniques described by Muller and Wagner (2009).

\section{Contour Data}

Where needed, additional valley cross-section data were obtained using 1- and 4-ft contour-interval data created from aerial photogrammetry collected in May 2007 (Eastern Topographics, 2007) and in April 2008 (Eastern Topographics, 2008). These data were referenced to the horizontal North American Datum of 1983 (NAD 83) and vertical NGVD 29 . The 1-ft contour-interval data were created for the reach of the Suncook River from Route 4 to approximately onefourth of a mile downstream of the Short Falls Road Bridge. These contour-interval data extend $660 \mathrm{ft}$ to either side of the Suncook River reach. The 4-ft contour-interval data were created for the reach of the Suncook River from the Short Falls Road Bridge to the confluence with the Merrimack River. These contour-interval data extend $1,000 \mathrm{ft}$ to either side of the Suncook River reach downstream of the Short Falls Road Bridge.

\section{Streamflow and Temperature Data}

Streamflow and temperature data are input parameters to the quasi-unsteady-state HEC-RAS (USACE, 2008a) sediment-transport model. In HEC-RAS, the only quantity directly related to temperature is viscosity, and its effect is seen only on the sediment-transport calculations within the model. Sediment quantities, such as sediment-transport capacity and particle-fall velocity, are indirectly related to temperature through viscosity; stream characteristics such as roughness or backwater effects, however, are independent of temperature. Daily mean streamflow and temperature data for WY 2008 and 2009 were obtained from the Suncook River streamgage and entered into the model. Daily mean streamflow data were adjusted for locations downstream of the streamgage, whereas daily mean temperature data were not adjusted for downstream locations.

\section{Streambed and Sediment Sampling}

Sediment-transport models require data on stream-channel geometry, flow, and water temperature as well as information on the distribution of particle size as input parameters. Data on stream-channel geometry and on streambed (bedmaterial) sediments were collected during WY 2008-2009 for model input, while total sediment load (suspended sediment plus bedload sediment) data was collected during the same period for model calibration. Sediment samples of streambed and streambank material were collected at 30 locations in the study reach (fig. 3 and appendix 1). Suspended- and bedloadsediment data and instantaneous streamflow data were collected during November 2007-May 2008 for flows between 65 and 2,410 ft $3 / \mathrm{s}$ at four bridge locations: Route 3 bridge in Allenstown (Suncook) and Pembroke; Route 28 bridge in Allenstown and Pembroke; Short Falls Road Bridge in Epsom; and Route 4 bridge in Epsom (fig. 3).

The study used the equal-discharge-increment (EDI) sampling method (Edwards and Glysson, 1999) to collect suspended- and bedload-sediment samples. Because this method requires knowledge of the distribution of streamflow in the cross section, the study obtained streamflow data in the field from discharge measurements made immediately prior to selecting sampling verticals. Using the EDI method, the study obtained samples from the centroids of equal-discharge increments, where the mean concentration is the average of the several sampling verticals. Three samplers were usedUS DH-48, US DH-95, and US D-95 (Edwards and Glysson, 1999). The US DH-48 is a lightweight, aluminum, hand-held depth-integrating sampler used in wadeable stream reaches. The US DH-95 sampler is a plastic-coated, low-lead bronzecast, hand-line sampler that can be used in streams up to $15 \mathrm{ft}$ deep and in velocities ranging from 1.7 to 7.4 feet per second 
$(\mathrm{ft} / \mathrm{s})$. The US D-95 sampler is a plastic-coated, bronze-cast, suspension-system (for example, reel-and-crane) sampler that can also be used in stream depths up to $15 \mathrm{ft}$ and stream velocities ranging from 1.5 to $7.5 \mathrm{ft} / \mathrm{s}$ (Davis, 2005).

Bedload-sediment samples were collected at the same four sampling sites and at the same time as the suspendedsediment samples (fig. 3) using US BLH-84 and US BL-84 samplers (Edwards and Glysson, 1999). The US BLH-84 sampler - a lightweight, aluminum, hand-held bedload sampler used in wadeable streams - has a nozzle width of $0.25 \mathrm{ft}(76.2 \mathrm{~mm})$. The sampler consists of an expanding nozzle, a sample bag, and a wading-rod assembly. The US BL-84 sampler is a stainless steel and aluminum cablesuspended bedload sampler used to collect samples from stream reaches that cannot be waded. The sampler consists of an expanding nozzle mounted in a frame and a sampler bag (Davis, 2005).

Because bedload samplers typically protrude above the bedload transport zone, they inevitably trap some suspended sediment. When bedload is transported over dunes, sediment carried over the separation zone in suspension may be trapped by a bedload sampler that is placed in or near the trough. This trapped sediment does not contribute to the downstream movement of the dune, and it is consistently finer in gradation and better sorted than at other locations over the dune. However, it causes distinctive temporal variability in the particle-size distribution in the bedload and may complicate estimating rates of bedload transport (Thomas, 1977). This effect was apparent at the collection site at the Short Falls Road Bridge during flows greater than the annual mean discharge.

Samples of suspended and bedload sediment and of bed material were analyzed by the USGS Kentucky Water Science Center (WSC) Sediment Laboratory for sediment concentration and for gradation of particle size. The Kentucky WSC Sediment Laboratory analyzed sediment ranging in size from $0.0625 \mathrm{~mm}$ (0.0025 in.) to $64 \mathrm{~mm}$ (2.5 in.). Sediment bed-material sizes measured using the US SAH-97 (gravelometer) ranged from $2 \mathrm{~mm}(0.08 \mathrm{in}$.) to more than $180 \mathrm{~mm}$ (7.09 in.). The field-collected total sediment (suspended-sediment plus bedload-sediment) discharge was compared with the model-determined total sediment discharge (based, in part, on bed-material gradation data) to aid in calibration and verification of the quasi-unsteadystate sediment-transport model. All resulting sediment data are stored in the USGS National Water Information System (NWIS, 2011) database.

To create sediment-gradation curves, the study determined the distribution of data on particle size from samples of streambed material collected in 2008. Selection of cross sections for bed-material sampling was determined on the basis of accessibility, of obvious visual change in bed material from upstream conditions, and on whether cross sections had constricted or nonconstricted areas. Bed material was obtained with grab samples using a US BMH-53, a shovel and (or) a US SAH-97 (Edwards and Glysson, 1999). The US BMH-53 is a hand-held piston-type tubular sampler that is used to collect a sample of material from the bed of a shallow stream. The US SAH-97 is an aluminum, hand-held analyzer that is used to grade or measure gravel- to cobble-sized bed sediments in the field. The US SAH-97 is also known generically as a gravelometer; it has 14 square openings ranging in size from $2 \mathrm{~mm}$ (0.08 in.) to $180 \mathrm{~mm}$ (7.09 in.) (Davis, 2005).

For substrate with material coarser than the mediumgravel limitation of the samplers, a pebble count was conducted using the US SAH-97 to measure surface particle size up to and greater than $180 \mathrm{~mm}$ (7.09 in.). A minimum of 100 particles of streambed material were manually collected from the cross section and measured (Wolman, 1954) to determine the distribution of particle size. Particles smaller than $2 \mathrm{~mm}$ in diameter were labeled " $<2 \mathrm{~mm}$."

\section{Simulation of Flow and of Sediment Transport}

HEC-RAS contains four one-dimensional components for analysis of rivers - computations of water-surface profiles of steady flow; simulation of unsteady flow; computations for movable-boundary transport of sediment; and analysis of water quality. HEC-RAS, version 4.0.0 (USACE, 2008a) was used in this study to model flow and sediment transport. It is a one-dimensional sediment-transport model that incorporates the sediment-transport functionality of HEC-6 (USACE, 1993) and is designed to calculate profiles of the water and sediment-bed surfaces by computing the interaction between sediment material in the streambed and the sediment mixture in the flowing water. The functionality of the sedimenttransport model simulates the capability of a stream to transport sediment, given the yield from upstream sources. This computation of transport includes both bedload and suspended sediment.

HEC-RAS performs computations of routing of mobile bed sediment using data from quasi-unsteady-state flow (histogram) series. The model also calculates hydraulic parameters required for sediment processes and uses various available methods to calculate sediment-transport capacity. In conjunction with sorting and armoring algorithms, the model solves the sediment-continuity equation to determine the volume of deposition or erosion. Additionally, functions of temporal entrainment and deposition of sediment have been adapted to HEC-RAS (Brunner and Gibson, 2005).

The sediment-transport component of the one-dimensional HEC-RAS continuous-simulation model uses a series of steady flows to represent the flow hydrograph; it is designed to simulate and predict changes in a river profile that result from aggradation or degradation of sand, silt, and clay. The HEC-RAS model incorporates flow hydraulics, sediment transport, channel roughness, and related changes in boundary geometry into the sediment-transport simulation.

In its sediment-transport function, the model partitions a continuous-flow record into a series of steady flows of variable discharges and duration. For each flow, it calculates a watersurface profile, thereby providing values of energy slope, 
velocity, depth, and other parameters of flow for each cross section. It then computes potential sediment-transport rates. These rates, combined with the duration of the flow, permit a volumetric accounting of sediment within each reach. The amount of scour or deposition at each section is then computed and the cross section adjusted accordingly. The computations proceed to the next flow in the sequence, and the cycle is repeated, beginning with the updated geometry. Using grainsize fraction, the sediment calculations are performed, thereby allowing the simulation of hydraulic sorting and armoring. The model output includes water-surface elevations; changes in elevation due to erosion or deposition; changes in streambed material, sediment concentrations, and sediment load; and bed shear stresses (USACE, 2008c). The potential uses for the output of the model are to evaluate erosion and deposition at the stream-reach scale, to estimate changes in water-surface elevations, and to assess the long-term stability of the river.

The Suncook River HEC-RAS sediment-transport simulation involved two steps. The first step simulated a steady-state fixed bed; the second step simulated a quasiunsteady-state moveable bed. The fixed-bed simulation involved hydraulic computation, which included determining water-surface profiles and flow velocities at each cross section along the study reach. The water-surface profile was calculated from downstream to upstream using the standard step-backwater method to solve the one-dimensional energy equation (USACE, 2008c).

\section{Initial- and Boundary-Condition Data}

The HEC-RAS quasi-unsteady-state sediment-transport model uses four categories of input data: three for initial conditions (hydrologic (with stream temperature), hydraulic, and sediment), and one for boundary conditions. The model requires the user to supply an upstream boundary condition for either an inflow sediment-load series, a rating curve, or an equilibrium load. The equilibrium-load option, which is based on sediment-transport capacity, was selected for this study.

\section{Hydrologic Data}

The HEC-RAS quasi-unsteady-state sediment-transport model simulation of changes in the channel bed requires the analysis of complete hydrographs; the analysis of a singleflowvalue, such as a flood peak, is thus not adequate for moveablebed model computation. Accordingly, a hydrograph was developed using daily mean streamflow values as determined at the Suncook River streamgage.

For forecasting the future streambed profile, the daily mean flow and temperature data for WY 2009 (October 1, 2008 through September 30, 2009) were used for simulating streamflow for both WY 2009 and 2010 (October 1, 2009 through September 30, 2010) at the Suncook River streamgage. The daily mean streamflow data were adjusted at locations of change in lateral-boundary flow (Flynn, 2010) downstream of the streamgage using the following drainagearea adjustment ratio (eqn. 3 ):

$$
Q / Q_{\mathrm{g}}=\left(A / A_{\mathrm{g}}\right)^{n},
$$

where

$Q \quad$ is the streamflow at the ungaged site, in cubic feet per second;

$Q_{\mathrm{g}} \quad$ is the streamflow at the USGS streamgage, in cubic feet per second;

$A$ is the drainage area at the ungaged site, in square miles;

$A_{\mathrm{g}} \quad$ is the drainage area at the USGS streamgage, in square miles; and

$n \quad$ is the drainage-area adjustment value.

\section{Hydraulic Data}

Analyses of hydraulic characteristics were carried out to provide estimates of the water-surface elevations of floods at the 50-, 20-, 10-, 4-, 2-, 1-, and 0.2-percent annual exceedence probabilities (recurrence intervals of 2, 5, 10, 25, 50, 100, and 500 years; respectively), and of the elevation of the April 2007 flood for the Suncook River (Flynn, 2010).

Starting elevations of water surface for the Suncook River were based on normal depth analysis, the depth at which flow is steady and hydraulic characteristics are uniform. The computational procedure for the HEC-RAS model is based on the solution of the one-dimensional energy equation (USACE, 2008b). Energy losses are caused by and evaluated through analyses of friction contraction, and expansion. The momentum equation is used in situations where the water surface is rapidly varied, such as in calculations of mixed-flow regimes (for example, hydraulic jumps) and of the hydraulics of bridges; it is also used in evaluating profiles at river confluences (stream junctions).

Manning's $n$ roughness coefficients (Barnes, 1967; Arcement and Schneider, 1989), used in the hydraulic computations, were assigned on the basis of engineering judgment and field observations of the stream and flood-plain areas. Manning's $n$ values for the Suncook River study reach ranged from 0.02 to 0.09 in the channel and from 0.02 to 0.12 on the channel overbanks. The hydraulic analyses for this study were based on an assumption of unobstructed flow. Therefore, the flood and streambed elevations shown in the profiles are considered valid if hydraulic structures remain unobstructed, operate properly, and do not fail. After calibration and verification, the steady-state flow-model-geometry data were imported into the quasi-unsteady-state sediment-transport model.

\section{Calibration of the HEC-RAS Hydraulic Model}

Calibrating the sediment model involved three steps. The steps include calibrating the steady-state Suncook River flow model to the flood of April 2007 (Flynn, 2008; 2010), 
importing the channel geometry data into the quasi-unsteadystate sediment-transport model, and calibrating the quasiunsteady-state flow model (using daily mean flow, watertemperature, and sediment data with various transport, sorting, and fall-velocity methods) to closely represent the change in the channel bedform that was observed in the field for the 400-day period between collection of cross-section data.

The Suncook River HEC-RAS steady-state flood model (Flynn, 2010) was calibrated using 22 high-water marks that were flagged and surveyed following the flood of April 16-18, 2007 (Flynn, 2008) by comparing the fieldsurveyed high-water-mark flood elevations (Flynn, 2008; 2010) with the water-surface elevations as simulated by the HEC-RAS model. The high-water marks typically consisted of debris lines, wash lines, or mud/silt lines left behind by the peak water surfaces during the flood.

In the second step, the hydraulic parameters determined in the steady-state simulation, along with sediment-gradation (variation of particle size in a sediment mixture) data and daily mean flow and temperature data for the calibration period, were imported into the quasi-unsteady-state sediment-transport model to simulate movable-bed evolution. The daily mean flows used in the model for simulation at locations of lateralboundary flow change (such as tributaries) were obtained from streamflow data with a drainage-area adjustment for the Suncook River streamgage (Flynn, 2008).

The greatest fluctuation in streambed elevation in the study reach has been the streambed reach of the Suncook River between the avulsion at the former sand pit and the Buck Street Dams (fig. 3), where moving sediment dunes have formed. For this reason, calibrating the sediment quasiunsteady-state model focused on assuring agreement between two sets of field-collected data on cross-section geometry - the Suncook River channel cross-section data along a 4.2-mi reach of the Suncook between the Buck Street Dams and Short Falls Road Bridge. On May 8, 2008, channel-bed profiles and cross sections of the 4.2-mi reach were determined using an ADCP and a surveying total station, along with differential leveling techniques. On June 11, 2009, the channel-bed profiles and cross sections were again measured, and this information was used in calibrating the sediment-transport model. This 400-day period was used for calibrating and verifying the model using daily mean flow and temperature data.

\section{HEC-RAS Sediment-Transport Function Selection}

Sediment-transport equations are used to compare sediment loads and energy. Predictions of channel changes are based on rates of erosion or deposition when future changes in the flow regime are expected. Erosion or deposition rates can be obtained from sediment-discharge formulas, principles of fluvial morphology, regime theory, or other methods that consider the forces exerted on the stream boundaries. However, streams continually adjust their dimensions to accommodate change in discharge and in sediment-transport regimes. The thresholds of sediment movement and transport will therefore vary temporally and spatially as the stream adjusts to variation in slope, bed material, and discharge.

The HEC-RAS sediment-transport model incorporates empirical-transport equations, and for each cross section, it computes the inflow-sediment load, thalweg profiles, gradation of material in the active layer, and the transport capacity. Transport equations that can be used in HEC-RAS include those given by Toffaleti (1968), Ackers and White (1973), Engelund-Hansen (1967), Laursen (1958) and Copeland (1989), Meyer-Peter Muller (1948), Yang (1973), and Wilcock (2001).

The Laursen (Copeland) transport function, in conjunction with the Exner 5 sorting method and the Report 12 (Interagency Committee on Water Resources, 1957) Fall Velocity Method were used for the forecast model. Exner 5 is a three-layer algorithm to compute bed-sorting mechanisms by separating the active layer into two sublayers and simulating coarsening of the streambed. After each timestep, the sediment cover layer is evaluated; if the bed is partially or fully armored, the amount of sediment material available to satisfy excess capacity can be limited (Gibson and others, 1996).

According to USEPA, sediment models using streampower equations are preferred because they include velocity and shear stress as components that are often associated with channel disturbance (USEPA, 2008e). The Laursen (1958) sediment-transport function is a total-load function of excess shear and the ratio of the shear velocity to the fall velocity. The Laursen equation was based on his original work with sand-bed streams and flumes. The flume experiments used median particle sizes ranging from 0.0004 to 0.1606 in. (0.011 to $4.08 \mathrm{~mm}$ ). Laursen supplemented the flume data with field observations of sediment discharge using median particle sizes ranging from 0.003 to 0.027 in. (0.08 to $0.7 \mathrm{~mm}$ ). Later work by Copeland (1989) generalized the equation for gravel transport so that the equation could be used for beds that included gravels up to a median size of $29 \mathrm{~mm}$ (coarse gravel). A distinctive feature of the Laursen (Copeland) equation is that it was developed for the range of sediment material extending to silt. None of the other functions currently included in HECRAS was developed for silt-sized particles. To use the other HEC-RAS functions for determining silt sediment potentials would have required extrapolations, thus compounding the standard uncertainty associated with computing transport capacity. Recent work at Colorado State University has determined that the Laursen equation outperforms other transport equations in the silt range (USACE, 2008c).

\section{Limitations of the HEC-RAS Model}

The HEC-RAS one-dimensional flow, sediment-transport, and sediment-degradation- and -aggradation model used in this study has a number of important limitations. 
1. The model is unable to simulate the development of meanders or to specify a lateral distribution of sediment load across a cross section. In one-dimensional modeling, the solution of the sediment-continuity equation provides a change in the simulated cross-sectional area. That change in area is equally allocated to each coordinate point across the cross section. But the shape of the cross section cannot be addressed with a one-dimensional sediment-transport model (ASCE, 2008). Therefore, the simulation's calculation of how sediment transport is allocated is only an approximation. In one-dimensional mobile-bed modeling, the heterogeneous processes of sediment entrainment, deposition, and movement are described for the cross section as a whole in the form of bulk channel properties. These properties include average velocity, overall discharge, average depth, bulk shear stress, and average composition of bed material in the section (ASCE, 2008).

2. Bedforms throughout the modeled reach are not simulated but can be approximated indirectly using Mannings $n$ values as a function of the river elevation or river discharge.

3. In comparing measured and simulated suspended-sediment discharges, reconciling differing scales can become a problem. Although the samples of suspended and bedload sediment represent a time-averaged sample at a particular cross section, it is not uncommon to see nonmonotonic patterns in the measured data, thus suggesting the existence of large-scale variability (large eddies, dune migration) that a numerical model cannot fully resolve (ASCE, 2008). For this study, however, the output data from the model were calibrated as closely as possible by comparing modeled sediment loads and streambed elevations with field-collected data for these parameters.

4. Distribution of sediment grain sizes may be representative for the location and time at which these data were taken, but size distributions collected at a particular location may not be representative of the general area of the river at the spatial or temporal scale that the model can resolve. Samples of bed material may also not be representative of a quasi-equilibrium bed condition for the width of the river for hundreds of feet of the river's length but instead more closely represent the portion of the dune from which they were taken or the finer material moving through the entire river system (ASCE, 2008).

\section{Markov Chain Analyses of Flow}

To enable the study to predict future sediment discharge for WY 2010, a hydrograph was developed to represent future flows. Analysis using Markov Chain Theory was chosen for the determination of future flows because it is applicable to processes that can be formulated in terms of discrete values as well as for continuous processes that can be discretized for computational convenience (Salas, 1993). At each step, the system may change its state or remain in the same state, according to a certain probability distribution. The changes of state are called "transitions," and the probabilities associated with various changes in state are called "transition probabilities." This study used Markov Chain Theory to determine the probability of occurrence of flows greater than and less than the annual peak flow and the annual mean flow (sum of all daily mean flows divided by the number of days in the year) based on historical data from the USGS Suncook River streamgage to aid in determining an appropriate simulated mean daily flow hydrograph for WY 2010. The initial data for the Markov Chain Theory analysis were drawn from the years during which the streamgage was operative only intermittently (1919-20, 1922-27, and 1929-77 with peak-flow data collected only during 1971-77).

A frequently used surrogate for the channel-forming discharge in empirical regression equations is the annual mean flow (Leopold and Maddock, 1953; Federal Interagency Stream Restoration Working Group (FISRWG), 1998). The annual mean flow is the equivalent of the discharge that would yield the same volume of water in a water year as the sum of all measured discharges (FISRWG, 1998). Leopold (1994) found a consistent proportion between annual mean flow and bankfull discharge within the same region-the ratio of bankfull discharge to annual mean discharge was found to be approximately 8.3 for 13 streamgages in the eastern United States. Assuming bankfull flow is equal to the 1.8-year recurrence-interval flood based on the historical record at the streamgage, a value of 5.5 was found to be the ratio of bankfull discharge to annual mean flow for WY 2009 at the Suncook River streamgage.

Because the annual mean flow is a surrogate for the channel-forming discharge (Leopold and Maddock, 1953; FISRWG, 1998), Markov Chain Theory analysis was used to assess data on the annual mean flow for the Suncook River streamgage during the record gap before the streamgage was reactivated in November 2007. For the 47 water years of record before 1971, the average of the annual mean flows at the Suncook streamgage is $237 \mathrm{ft} / \mathrm{s}$; when incorporating the annual mean flow for WY 2008 and 2009, the average of the annual mean flow for the 49 water years of record is $243 \mathrm{ft}^{3} / \mathrm{s}$. The maximum annual mean flow for the historical Suncook streamgage data (before the 2007 reactivation) was $346 \mathrm{ft}^{3} / \mathrm{s}$ in 1953, and the minimum annual mean flow was $96 \mathrm{ft}^{3} / \mathrm{s}$ in 1965.

The Suncook streamgage was not active during October 1 through November 9, 2007. For the partial WY 2008 beginning November 9, 2007 through September 30, 2008, the annual mean flow was $418 \mathrm{ft}^{3} / \mathrm{s}$, and for the full WY 2009 (October 1, 2008 through September 30, 2009), the annual mean flow was $375 \mathrm{ft}^{3} / \mathrm{s}$. The annual mean flows for these two water years were 20.8 and 8.4 percent greater, respectively, than the maximum annual daily mean flow of $346 \mathrm{ft}^{3} / \mathrm{s}$ that occurred in WY 1953. 
These annual mean flows for WY 2008 and 2009 are 76.4 and 58.2 percent greater, respectively, than the average annual mean flow $\left(237 \mathrm{ft}^{3} / \mathrm{s}\right)$ for the water years before the streamgage was reactivated in November 2007. The study used the historical Suncook River streamgage maximum annual mean flow value of $346 \mathrm{ft}^{3} / \mathrm{s}$ as a benchmark to estimate the probability of an annual mean flow greater than the pre-1971 annual mean flow of $237 \mathrm{ft}^{3} / \mathrm{s}$ but less than the annual mean flow values for WY 2008 and 2009. Using Markov Chain Theory to analyze the period of record (1919-70) for annual mean flow, the study determined that the probability of an annual mean flow greater than $346 \mathrm{ft}^{3} / \mathrm{s}$ in any given year is 0.02 ; conversely, the probability of annual mean flow less than $346 \mathrm{ft}^{3} / \mathrm{s}$ in any given year is 0.98 . The WY 2009 annual mean flow was $375 \mathrm{ft}^{3} / \mathrm{s}$.

The annual peak-flow data at the Suncook River streamgage were also analyzed using Markov Chain Theory for water years (October 1-September 30) other than 2007. For WY 2006, the peak flow was determined to be 7,600 $\mathrm{ft}^{3} / \mathrm{s}$ (Olson, 2007). For WY 2007, the peak flow was determined to be $10,600 \mathrm{ft}^{3} / \mathrm{s}$ (Flynn, 2008). For WY 2008, the peak flow was determined to be $3,430 \mathrm{ft}^{3} / \mathrm{s}$. Using Markov Chain Theory to analyze the streamgage record from 1919-77, it was determined that the probability, in any given year, of a peak flow greater than that of WY 2008 (the lowest among the annual peaks of WY 2006, 2007, and 2008) at 3,430 ft/s, would have been 0.24 . The annual peak flow for WY 2009 was $2,500 \mathrm{ft}^{3} / \mathrm{s}$; it occurred on November 26, 2008. Using the streamgage record from 1919-77, the study determined that the probability, in any given year, of a peak annual flow greater than the provisional annual peak for WY 2009 of 2,500 ft3 $/ \mathrm{s}$ would be only 0.36 . On the basis of these analyses of annual peak flow since the Suncook River streamgage was reactivated and of annual mean flow data for partial WY 2008 and 2009, and because the probability of an annual mean flow being greater than $346 \mathrm{ft}^{3} / \mathrm{s}$ in any year before 1971 is 0.02 , it was determined that a hydrograph using the mean daily flow data for WY 2009 would best represent the mean daily flow regime for WY 2010 for predicting sediment transport.

\section{Geophysical Data}

Geophysical data-collection activities, using direct-current (DC) electrical resistivity methods, were conducted during summer 2008 in the area of the sand pit to determine the depth of the surficial sediment layer. The electrical resistivity of the subsurface materials can be used to characterize lithologic materials. A consolidated layer, such as bedrock, would have a higher resistivity response than gravel, which would have a higher resistivity response than sand. Apparent resistivity is calculated from electrical resistivity values and geometric factors such as electrode spacing and the arrangement of current and potential electrodes in relation to each other. Variation in apparent resistivity indicates the existence of zones of contrasting resistivity, which under ambient water-quality conditions specifies differing lithologic materials. Data are inverted to convert apparent resistivity values into estimates of values at specific depths.

\section{Channel Morphology and Stream Processes}

The total sediment loads collected at the four bridge locations along the Suncook River were primarily suspended sediment. Analysis of sediment occurrence and transport indicated that the median grain size $\left(d_{50}\right)$ of all sediment sample locations in the Suncook River typically corresponded to coarse gravel $\left(d_{50}\right.$ of 16-32 $\left.\mathrm{mm}\right)$ above the avulsion and coarse sand ( $d_{50}$ of 0.5 to $\left.1 \mathrm{~mm}\right)$ below the avulsion. Degradation is the dominant process for channel adjustment in the Suncook River at and above the avulsion site. Severe degradation of greater than $14 \mathrm{ft}$ has occurred at the location of the May 2006 avulsion of the Suncook River, and an active headcut has moved upstream to an area above the river's confluence with the Little Suncook River (figs. 2, 4C). The elevation of the thalweg of the headcut that is advancing upstream at cross section DG is $302.7 \mathrm{ft}$ (NGVD 29). Cross section DG is approximately $1,000 \mathrm{ft}$ downstream of the upstream face of the Route 4 bridge (figs. 4D and C). Potentially, a consolidated layer, such as shown in cross section DG, could halt the advancement of the headcut before it reaches the Route 4 bridge if this resistive layer is bedrock (elevation of $305 \mathrm{ft}(+5 \mathrm{ft}$ ), NGVD 29 ) and if it extends downstream of the Route 4 bridge at an elevation greater than $302.7 \mathrm{ft}$ (NGVD 29), the elevation of the headcut thalweg. Downstream of the avulsion and former sand pit, aggradation is the dominant process of channel adjustment. Significant aggradation has occurred above and below Round Pond in the area adjacent to the production well (fig. 2) and, in particular, in the reach between the former sand pit and the Buck Street Dams (figs. 4A and B).

\section{Lateral Migration of Streambed}

Mass failure of steep, cohesive banks is a function of bank height, bank angle, and soil properties. Downstream of the confluence area and upstream of the large meander bends (fig. $4 \mathrm{C}$, cross sections $\mathrm{CB}$ to $\mathrm{CI}$ ), a small vegetated berm is keeping the channel in its present (2010) location. A small flood-bypass channel on the west side of the river at the first of the large meander bends splits the flow and may eventually cause the river to completely bypass the first meander bend (fig. 4C, cross sections CG to CI). If allowed to evolve naturally over time, the form and location of the channel will likely change between Round Pond and the large meander bends. These changes (2010) are occurring in the form of an avulsion at Round Pond and at the first of the large meander bends where flow now occurs through the flood-bypass channel west of the river. Lateral migration of the river into the large field 
area east of the river and (or) formation of multiple channels may also occur. In addition, sediment will continue to fill in the channel, with the most significant aggradation occurring between the sand pit area and the Buck Street Dams.

An historical analysis of the width of the meander belt and the river's migration rates by VHB, Inc. (written commun., 2007) determined that, in spite of its sinuosity, the preavulsion Suncook River had been stable, its lateral migration rate remaining at $4 \mathrm{~cm}$ per year during the 50-year period 1953-2003. However, the new channel through the area of the former sand pit is unstable and will actively continue to adjust. Despite its instability since the May 2006 avulsion, there has been little lateral migration in the new channel. The top of banks were delineated in figure $5 \mathrm{~A}(1: 2,500)$ based on aerial photography from a flight on May 12, 2007 (Eastern Topographics, 2007). In figure 5B $(1: 2,500)$, the delineation of the top of bank on May 12, 2007 has been superimposed over an aerial photograph taken on April 18, 2008 (Eastern Topographics, 2008). Figures 5A and B show that, while the new avulsion channel reach is continuing to transport and deposit sediment, and bank erosion is occurring, there was little lateral migration of the new channel through the sand pit during the 11-month interval between May 2007 and April 2008.

\section{Distribution of Sediment Grain Size}

Streambed sediment-size gradation was determined for 30 locations in the study reach (fig. 4), with four locations corresponding to the bridges where samples were collected for the determination of total sediment load (suspended and bedload). The sediment grain size (appendix 1, figs. 6A-C) and median grain size $\left(d_{50}\right)$ (appendix 1, fig. 7) of the streambed material collected at the sampling locations ranged from less than $0.0625 \mathrm{~mm}$ (0.0025 in.) (silt/clay) to more than $180 \mathrm{~mm}$ (more than 7.1 in.) (large cobbles). The $d_{50}$ for the stream overbank bed material ranged from less than $0.0625 \mathrm{~mm}$ (less than $0.0025 \mathrm{in}$.) (silt/clay) to $58.8 \mathrm{~mm}$ (2.3 in.) (very coarse gravel) (appendix 1). Data for the $d_{50}$ indicated a smaller median grain size for the overbanks than for the stream, with the exception of one bed-material sampling location (SRM-280). The median grain size $\left(d_{50}\right)$ for all of the sediment-sampling locations upstream of the avulsion was an average of $45.7 \mathrm{~mm}$ (very coarse gravel) for the streambed and an average of $18.3 \mathrm{~mm}$ (coarse gravel) for the streambed and banks. The $d_{50}$ downstream of the avulsion for all of the sedimentsampling locations was an average of $3.66 \mathrm{~mm}$ (very fine gravel) for the streambed and an average of $0.56 \mathrm{~mm}$ (coarse sand) for the streambed and banks.

At Route 4, the median grain size of the streambed is small cobble $\left(d_{50}\right.$ grain size of $\left.109 \mathrm{~mm}\right)$ downstream of the bridge and coarse gravel upstream of the bridge $\left(d_{50}\right.$ grain size of $26 \mathrm{~mm}$ ); at Short Falls, median grain size is coarse sand $\left(d_{50}\right.$ grain size of $0.69 \mathrm{~mm}$ ); at Route 28 , median grain size is coarse silt ( $d_{50}$ grain size less than $\left.0.0625 \mathrm{~mm}\right)$; and at Route 3 , median grain size is medium sand $\left(d_{50}\right.$ grain size of $0.38 \mathrm{~mm}$ ). At the downstream face of the Route 4 bridge (appendix 1, SRM-80 site), 6 percent of the sediment in the streambed is finer than medium sand (less than $0.25 \mathrm{~mm}$ ), 18 percent is finer than very coarse sand (less than $1 \mathrm{~mm}$ ), 19 percent is finer than fine gravel (less than $4 \mathrm{~mm}$ ), and 100 percent is finer than small boulder (less than $256 \mathrm{~mm}$ ). At the downstream face of the Short Falls Road Bridge (appendix 1, SRM-238 site), 4 percent of the sediment in the streambed is finer than medium sand (less than $0.25 \mathrm{~mm}$ ), 75 percent is finer than very coarse sand (less than $1 \mathrm{~mm}$ ), and 100 percent is finer than medium gravel (less than $8 \mathrm{~mm}$ ). At the downstream face of the Route 28 bridge (above the Buck Street Dams) (appendix 1, SRM-280 site), 54 percent of the sediment in the streambed is finer than very fine sand (less than $0.063 \mathrm{~mm}$ ) and 100 percent is finer than very fine gravel (less than $2 \mathrm{~mm}$ ). At the downstream face of the Route 3 bridge (appendix 1, Route 3 site), 20 percent of the sediment in the streambed is finer than medium sand (less than $0.25 \mathrm{~mm}$ ), 97 percent is finer than very coarse sand (less than $1 \mathrm{~mm}$ ), 99 percent is finer than very fine gravel (less than $2 \mathrm{~mm}$ ), and 100 percent is finer than medium gravel (less than $8 \mathrm{~mm}$ ).

The particle-size gradation data and curves (figs. 6A-C, appendix 1) show that the streambed material is more coarse upstream of the avulsion, transitioning downstream from a median grain size of small cobble at the Route 4 bridge to coarse sand at the Short Falls Road Bridge to coarse silt at the Route 28 bridge. Downstream of the Route 28 bridge and the Buck Street Dams, the median grain size is larger - a medium sand. This gradation confirms that most of the finer sand and silt are falling out of suspension in the reach between the Short Falls Road Bridge and the Buck Street Dams, just below the Route 28 bridge.

After the May 2006 avulsion, the sediment load in the Suncook River increased substantially but, as the river moves toward equilibrium, it is anticipated that the erosion of bed sediments will gradually decrease in the new channel, with bed degradation reducing the channel slope (Lane, 1955) near the avulsion channel. The expected result is that the median particle size of the bed sediment will gradually increase. On the overbanks between the avulsion and the Buck Street Dams and in the channel from cross section $\mathrm{CN}$ to the Buck Street Dams (figs. 4B to C), however, much of the fine silt and sand that was deposited during the May 2006 and April 2007 floods has been retained. This overbank material washes into the river during precipitation events and is carried and deposited by flow in the channel and on the overbanks. 


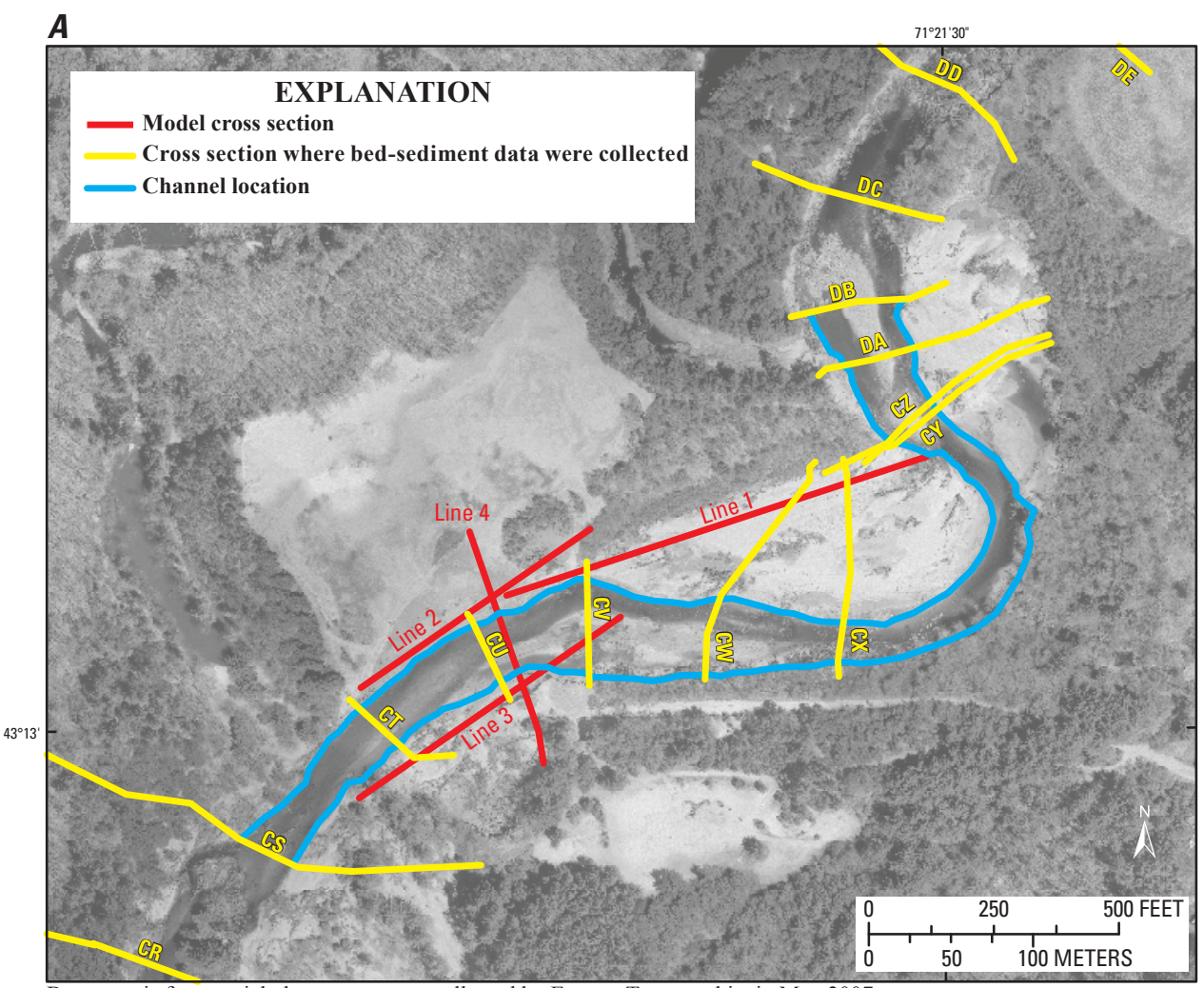

Base map is from aerial photogrammetry collected by Eastern Topographic, in May 2007 and May 2005, New Hampshire Department of Transportation tif imagery.

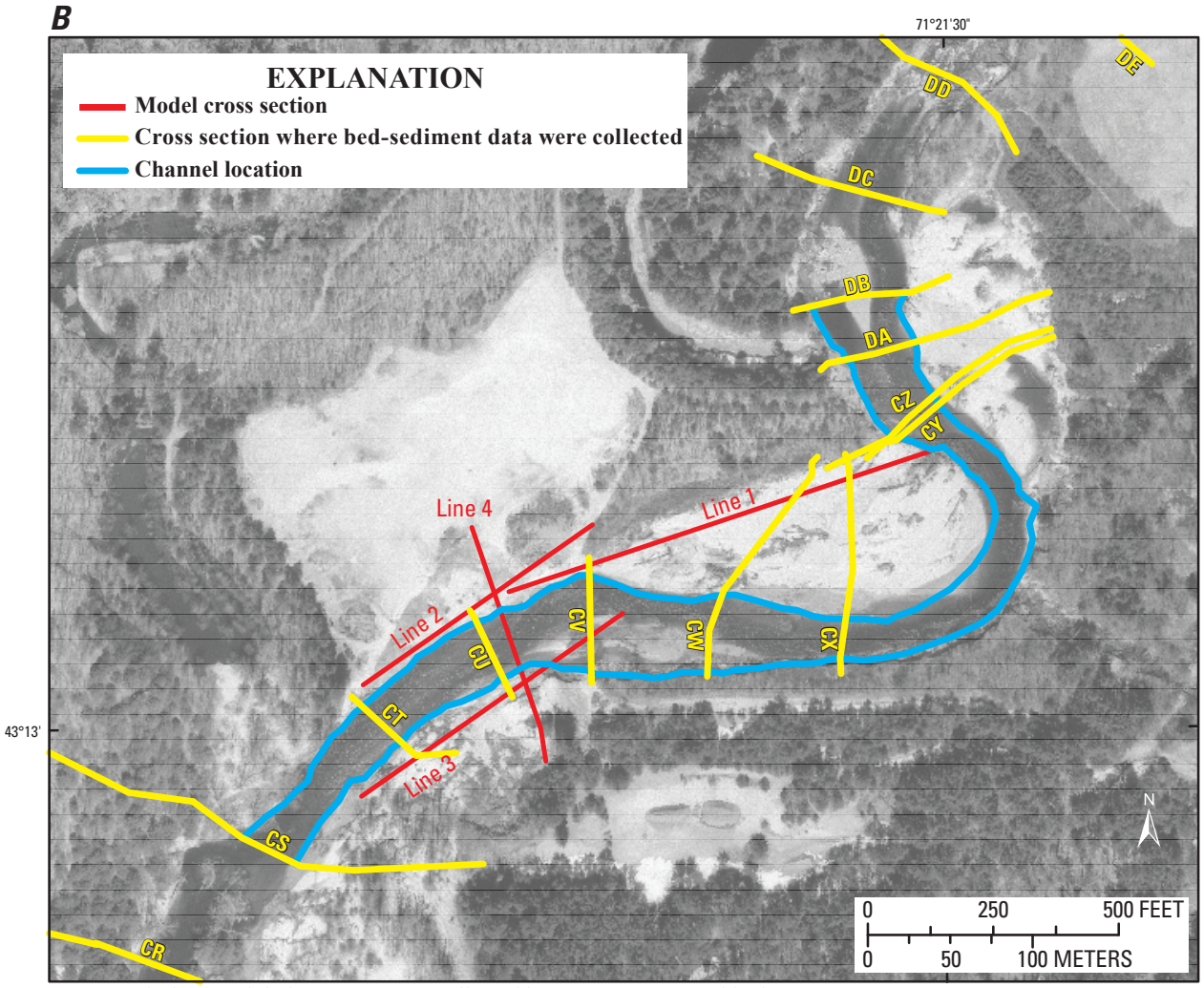

Base map is from aerial photogrammetry collected by Eastern Topographic, in May 2007, and May 2005, New Hampshire Department of Transportation tif imagery.
Figure 5A-B. A, May 2007 and $B$, April 2008 aerial imagery of the avulsion and former sand pit showing the May 2007 channel location and geophysical-survey cross sections (lines $1-4$ ) and model cross sections $\mathrm{CR}$ through DD $(1: 25,000)$. 


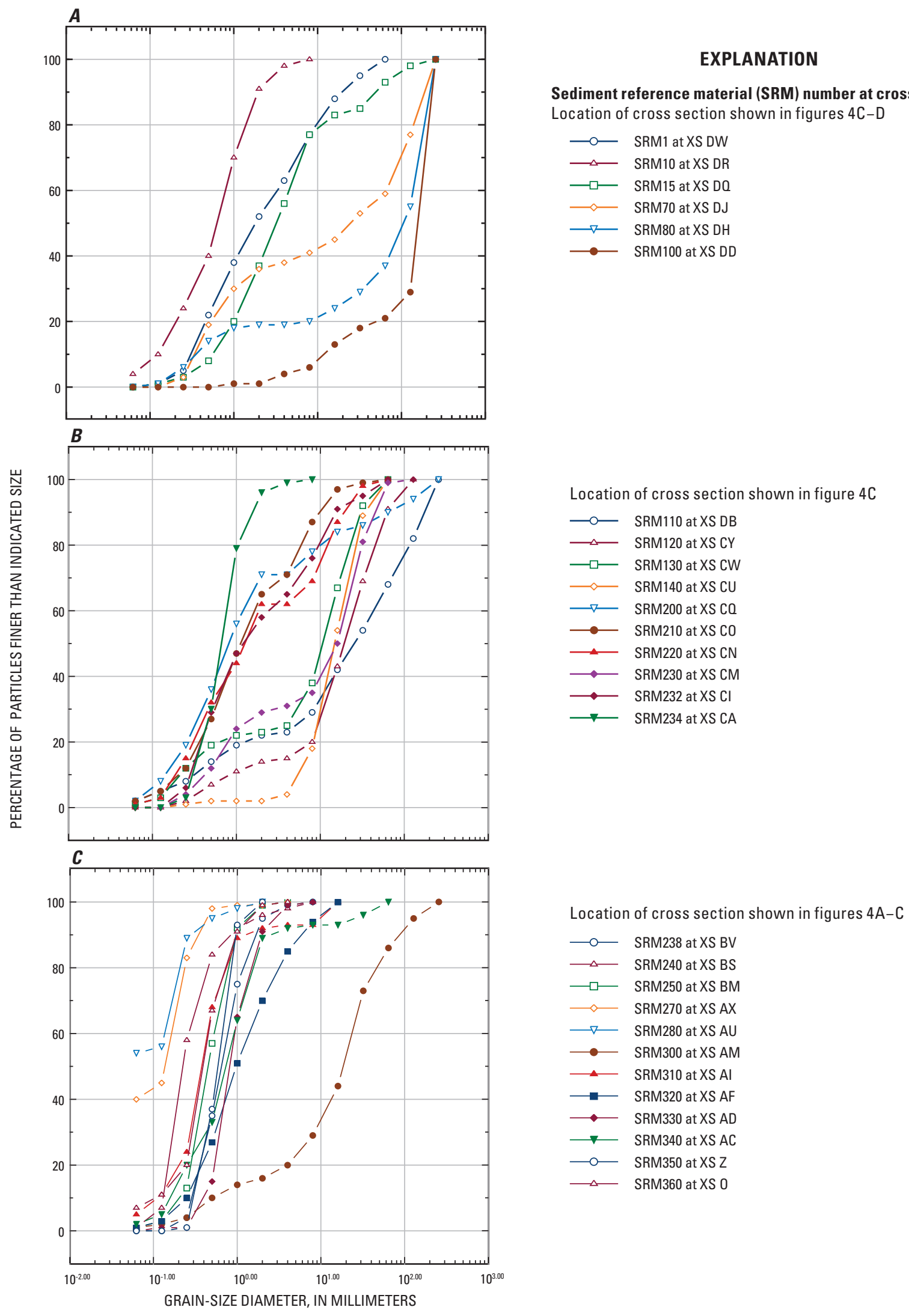

Figure 6A-C. A, Streambed-sediment grain-size distribution at six cross sections on the Suncook River upstream of the May 2006 avulsion, $B$, streambed-sediment grain-size distribution at ten cross sections on the Suncook River between the May 2006 avulsion and Short Falls Road Bridge, and $C$, streambed-sediment grain-size distribution at ten cross sections on the Suncook River downstream of the Short Falls Road Bridge. 


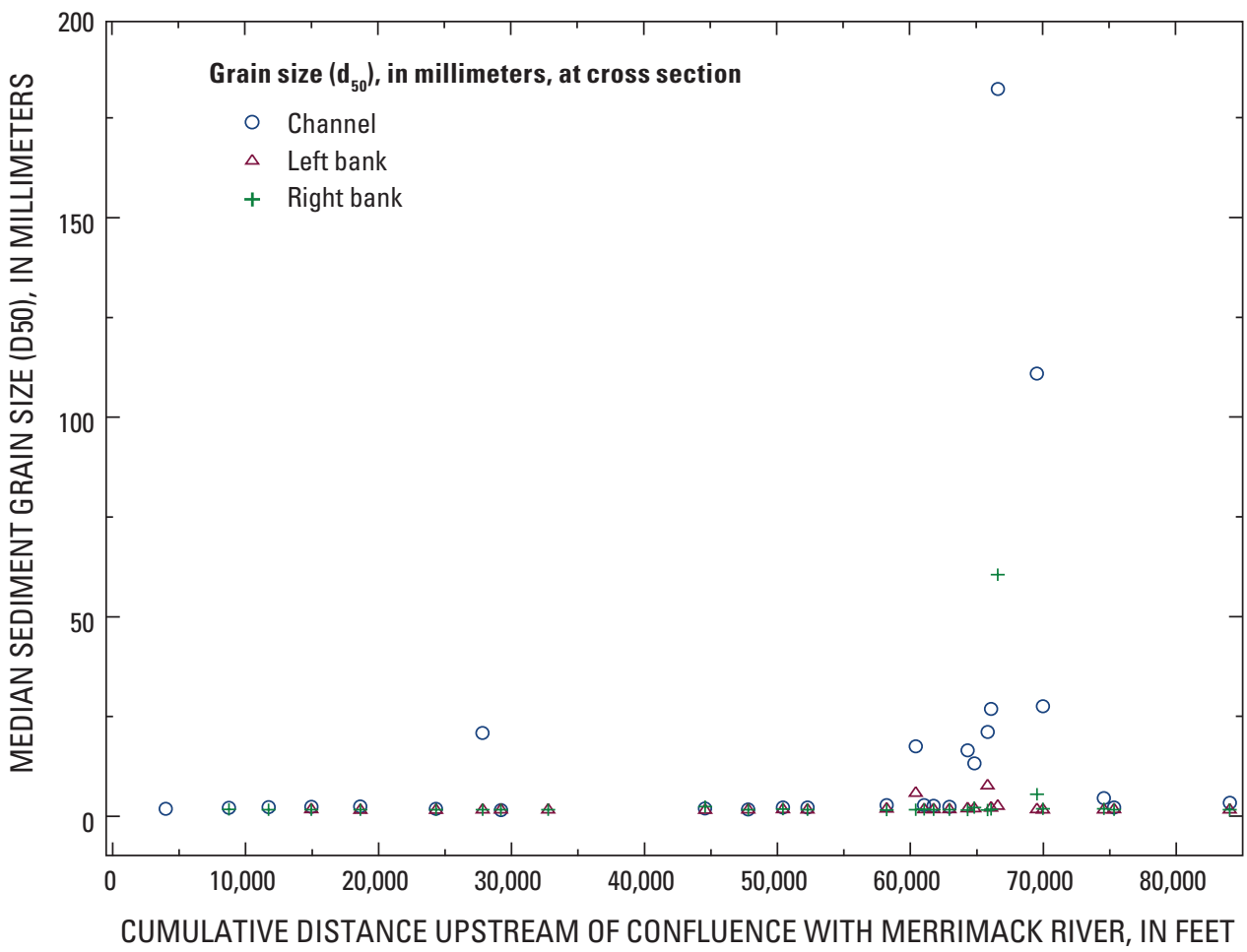

Figure 7. Median sediment grain sizes $\left(d_{50}\right)$ for the Suncook River in Epsom, Pembroke, and Allenstown, New Hampshire.

\section{Bankfull Channel Dimensions}

Bankfull dimensions were not identifiable in the new channel of the Suncook River because the channel is still actively adjusting. Wolman and Leopold (1957) suggested that the channel-forming discharge has a recurrence interval of between 1 and 2 years. However, there is no universally accepted definition of bankfull discharge or stage that can be consistently applied and that also integrates all the processes that create the bankfull dimensions of the river. The present study assumes that bankfull discharge is the flow having a recurrence interval of 1.8 years, which corresponds to a flow of $2,060 \mathrm{ft}^{3} / \mathrm{s}$ at the Suncook River streamgage. The variability of the bankfull-flow mean depth in the channel reach (fig. 8A and table 2) and the variability of the bankfull-flow top width (fig. 8B and table 2) of the channel reach, along with figures 6 and 7, indicate the Suncook River geomorphic structure.

\section{HEC-RAS Sediment-Transport Model}

The HEC-RAS steady-state flow model used to create the quasi-unsteady-state sediment-transport model was developed and calibrated using stream-channel cross-section geometry data and April 2007 high-water floodmark data (Flynn, 2010). A comparison of the HEC-RAS model calibration of the April 2007 flood to 13 surveyed high-water marks rated as "good" yielded an average elevation difference of $0.14 \mathrm{ft}$ (approximately 1.7 in.) and a standard deviation of 0.55 (Flynn, 2010). Following verification of the steady-state flow model, a 400-day quasi-unsteady-state calibration model was validated for sediment transport by comparing field-collected total load (suspended and bedload) data (table 3) with the HEC-RAS simulation results for total sediment load determined using field-collected streambed-material data and the Laursen (Copeland) sediment-transport equation. In the model simulations, the Laursen (Copeland) equation, in conjunction with the Exner 5 sorting method and the Report 12 (Interagency Committee on Water Resources, 1957) fall velocity method, were found to most closely simulate the streambed conditions for the 400-day calibration period and the field-collected total sediment loads. 

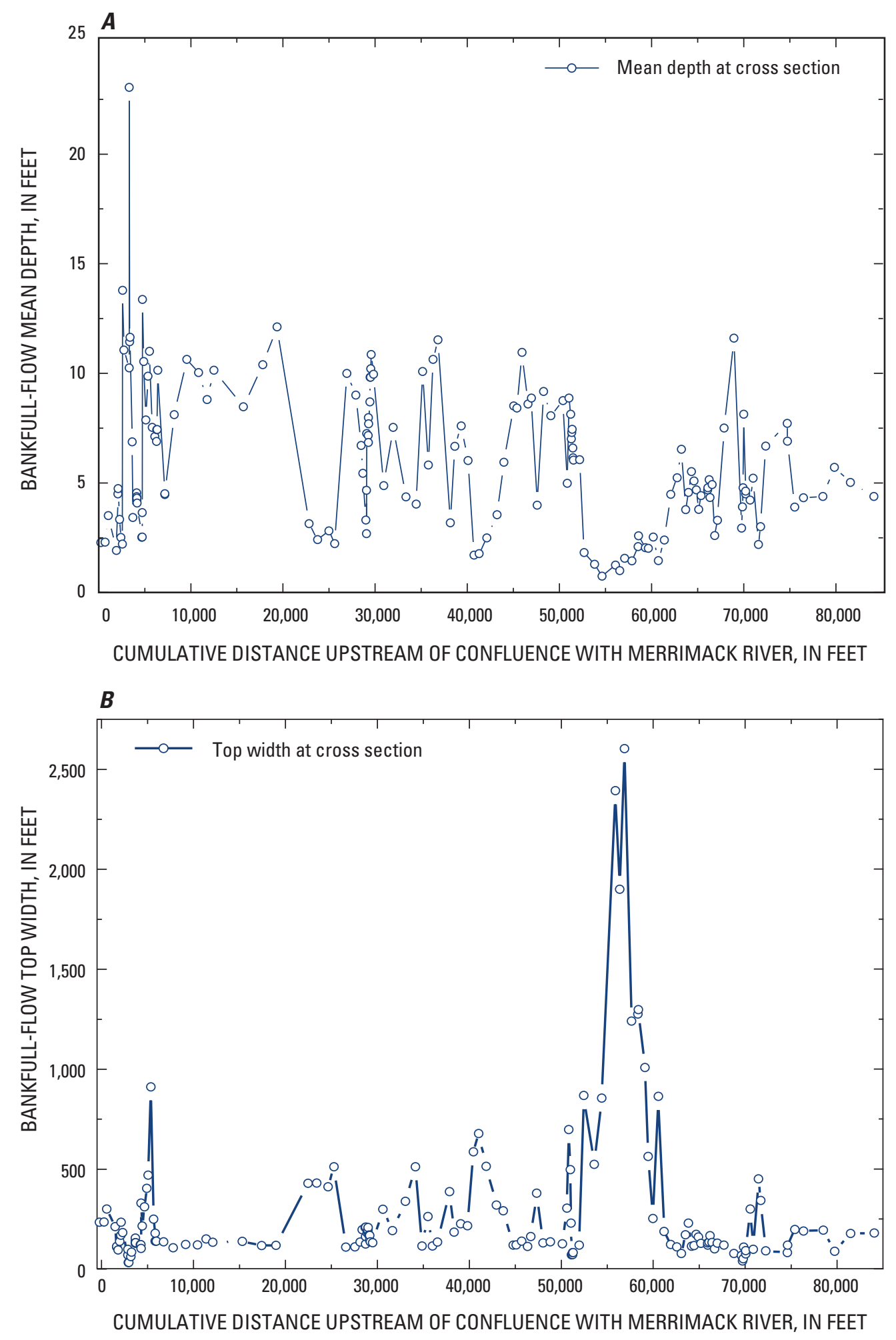

Figure 8. A, Bankfull-flow mean depth and $B$, bankfull-flow top width of the Suncook River in Epsom, Pembroke, and Allenstown, New Hampshire. 
Table 2. Bankfull-flow mean depth and top width of the Suncook River in Epsom, Pembroke, and Allenstown, New Hampshire. [ft, feet]

\begin{tabular}{|c|c|c|c|c|c|c|c|}
\hline $\begin{array}{l}\text { Suncook } \\
\text { River cross } \\
\text { section }\end{array}$ & $\begin{array}{c}\text { Cumulative } \\
\text { distance upstream } \\
\text { (ft) }\end{array}$ & $\begin{array}{l}\text { Bankfull flow } \\
\text { top width } \\
\text { (ft) }\end{array}$ & $\begin{array}{l}\text { Bankfull flow } \\
\text { depth } \\
\text { (ft) }\end{array}$ & $\begin{array}{c}\text { Suncook } \\
\text { River cross } \\
\text { section }\end{array}$ & $\begin{array}{c}\text { Cumulative } \\
\text { distance upstream } \\
\text { (ft) }\end{array}$ & $\begin{array}{l}\text { Bankfull flow } \\
\text { top width } \\
\text { (ft) }\end{array}$ & $\begin{array}{l}\text { Bankfull flow } \\
\text { depth } \\
\text { (ft) }\end{array}$ \\
\hline $\mathrm{A}$ & 0 & 241.71 & 2.27 & $\mathrm{Y}$ & 7,981 & 116.44 & 8.10 \\
\hline B & 477 & 242.14 & 2.28 & Z & 9,331 & 131.77 & 10.63 \\
\hline $\mathrm{C}$ & 804 & 307.24 & 3.50 & AA & 10,614 & 130.42 & 10.03 \\
\hline \multirow[t]{2}{*}{$\mathrm{D}$} & 1,681 & 220.12 & 1.90 & $\mathrm{AB}$ & 11,542 & 159.05 & 8.80 \\
\hline & 1,883 & 122.48 & 4.74 & $\mathrm{AD}$ & 15,482 & 147.18 & 8.47 \\
\hline $\mathrm{E}$ & 2,043 & 104.86 & 3.33 & $\mathrm{AE}$ & 17,581 & 127.06 & 10.39 \\
\hline \multirow[t]{2}{*}{$\mathrm{F}$} & 2,193 & 147.63 & 2.50 & $\mathrm{AF}$ & 19,123 & 128.07 & 12.12 \\
\hline & 2,337 & 178.07 & 2.20 & $\mathrm{AG}$ & 22,592 & 433.85 & 3.12 \\
\hline \multirow{3}{*}{$\mathrm{H}$} & 3,093 & 107.92 & 23.05 & $\mathrm{AK}$ & 26,696 & 118.66 & 9.99 \\
\hline & 3,124 & 43.47 & 11.45 & $\mathrm{AL}$ & 27,674 & 119.61 & 9.00 \\
\hline & 3,176 & 43.48 & 11.64 & $\mathrm{AM}$ & 28,253 & 144.39 & 6.71 \\
\hline I & 3,401 & 73.01 & 6.87 & $\mathrm{AN}$ & 28,443 & 205.77 & 5.42 \\
\hline $\mathrm{J}$ & 3,467 & 95.38 & 3.40 & $\mathrm{AO}$ & 28,766 & 215.08 & 3.30 \\
\hline \multirow[t]{4}{*}{ K } & 3,880 & 149.03 & 4.53 & AP & 28,851 & 171.70 & 4.65 \\
\hline & 3,889 & 164.29 & 4.32 & & 28,852 & 134.03 & 2.67 \\
\hline & 3,898 & 140.84 & 4.36 & & 28,866 & 217.69 & 7.24 \\
\hline & 3,907 & 140.06 & 4.29 & & 29,011 & 188.52 & 7.15 \\
\hline \multirow{2}{*}{$\mathrm{N}$} & 4,509 & 113.49 & 3.63 & & 29,285 & 153.80 & 10.21 \\
\hline & 4,525 & 335.92 & 13.38 & AT & 29,347 & 145.28 & 10.86 \\
\hline $\mathrm{O}$ & 4,640 & 223.98 & 10.53 & $\mathrm{AU}$ & 29,600 & 140.97 & 9.96 \\
\hline $\mathrm{P}$ & 4,886 & 318.31 & 7.86 & AV & 30,715 & 306.09 & 4.87 \\
\hline Q & 5,126 & 409.32 & 9.87 & AW & 31,747 & 200.35 & 7.53 \\
\hline $\mathrm{R}$ & 5,283 & 474.47 & 11.00 & $\mathrm{AX}$ & 33,142 & 344.68 & 4.35 \\
\hline $\mathrm{S}$ & 5,575 & 909.94 & 7.52 & AY & 34,227 & 515.28 & 4.02 \\
\hline $\mathrm{T}$ & 5,860 & 256.59 & 7.10 & $\mathrm{AZ}$ & 34,927 & 125.35 & 10.08 \\
\hline \multirow[t]{3}{*}{$\mathrm{U}$} & 6,045 & 186.98 & 6.88 & $\mathrm{BA}$ & 35,563 & 270.16 & 5.80 \\
\hline & 6,057 & 148.09 & 7.42 & $\mathrm{BB}$ & 36,078 & 125.34 & 10.63 \\
\hline & 6,109 & 148.14 & 7.43 & $\mathrm{BC}$ & 36,613 & 143.96 & 11.52 \\
\hline $\mathrm{V}$ & 6,172 & 149.62 & 10.13 & $\mathrm{BD}$ & 37,933 & 392.19 & 3.17 \\
\hline W & 6,935 & 144.86 & 4.46 & $\mathrm{BE}$ & 38,426 & 193.70 & 6.66 \\
\hline$X$ & 6,945 & 144.93 & 4.50 & $\mathrm{BF}$ & 39,121 & 234.26 & 7.59 \\
\hline
\end{tabular}


Table 2. Bankfull-flow mean depth and top width of the Suncook River in Epsom, Pembroke, and Allenstown, New Hampshire. -Continued

[ft, feet]

\begin{tabular}{|c|c|c|c|c|c|c|c|}
\hline $\begin{array}{l}\text { Suncook } \\
\text { River cross } \\
\text { section }\end{array}$ & $\begin{array}{c}\text { Cumulative } \\
\text { distance upstream } \\
\text { (ft) }\end{array}$ & $\begin{array}{l}\text { Bankfull flow } \\
\text { top width } \\
\text { (ft) }\end{array}$ & $\begin{array}{c}\text { Bankfull flow } \\
\text { depth } \\
\text { (ft) }\end{array}$ & $\begin{array}{c}\text { Suncook } \\
\text { River cross } \\
\text { section }\end{array}$ & $\begin{array}{c}\text { Cumulative } \\
\text { distance upstream } \\
\text { (ft) }\end{array}$ & $\begin{array}{l}\text { Bankfull flow } \\
\text { top width } \\
\text { (ft) }\end{array}$ & $\begin{array}{c}\text { Bankfull flow } \\
\text { depth } \\
\text { (ft) }\end{array}$ \\
\hline $\mathrm{BG}$ & 39,861 & 224.96 & 6.01 & $\mathrm{CO}$ & 61,868 & 131.91 & 4.47 \\
\hline $\mathrm{BH}$ & 40,506 & 588.58 & 1.68 & $\mathrm{CP}$ & 62,547 & 120.04 & 5.22 \\
\hline $\mathrm{BI}$ & 41,066 & 679.52 & 1.76 & CQ & 63,035 & 88.23 & 6.52 \\
\hline BJ & 41,899 & 517.94 & 2.47 & $\mathrm{CR}$ & 63,475 & 179.94 & 3.77 \\
\hline $\mathrm{BL}$ & 43,741 & 298.78 & 5.93 & $\mathrm{CT}$ & 64,132 & 123.86 & 5.51 \\
\hline $\mathrm{BM}$ & 44,821 & 128.83 & 8.51 & $\mathrm{CU}$ & 64,400 & 127.09 & 5.08 \\
\hline $\mathrm{BN}$ & 45,161 & 130.57 & 8.41 & $\mathrm{CV}$ & 64,632 & 182.67 & 4.67 \\
\hline $\mathrm{BO}$ & 45,724 & 149.62 & 10.96 & $\mathrm{CW}$ & 64,893 & 169.08 & 3.78 \\
\hline BS & 48,053 & 140.17 & 9.17 & DA & 66,029 & 144.11 & 5.14 \\
\hline BT & 48,853 & 144.98 & 8.06 & DB & 66,140 & 174.89 & 4.32 \\
\hline $\mathrm{BU}$ & 50,158 & 135.74 & 8.74 & $\mathrm{DC}$ & 66,345 & 142.41 & 4.92 \\
\hline BV & 50,624 & 312.19 & 4.96 & $\mathrm{DD}$ & 66,627 & 110.65 & 2.59 \\
\hline \multirow[t]{2}{*}{ BW } & 50,829 & 698.44 & 8.86 & $\mathrm{DE}$ & 66,929 & 138.82 & 3.29 \\
\hline & 50,989 & 501.02 & 8.13 & $\mathrm{DF}$ & 67,651 & 128.58 & 7.49 \\
\hline \multirow[t]{3}{*}{$\mathrm{BX}$} & 51,081 & 237.77 & 7.00 & DG & 68,733 & 87.87 & 11.60 \\
\hline & 51,134 & 81.95 & 7.29 & $\mathrm{DH}$ & 69,552 & 77.84 & 2.92 \\
\hline & 51,175 & 82.76 & 7.44 & & 69,665 & 50.78 & 3.89 \\
\hline $\mathrm{CC}$ & 54,415 & 853.95 & 0.73 & $\mathrm{DM}$ & 71,389 & 455.23 & 2.17 \\
\hline $\mathrm{CD}$ & 55,869 & $2,368.69$ & 1.24 & $\mathrm{DN}$ & 71,617 & 348.61 & 2.99 \\
\hline $\mathrm{CE}$ & 56,345 & $1,883.13$ & 0.98 & DO & 72,166 & 101.25 & 6.67 \\
\hline $\mathrm{CF}$ & 56,880 & $2,575.37$ & 1.54 & DP & 74,513 & 91.50 & 7.71 \\
\hline $\mathrm{CG}$ & 57,636 & $1,233.32$ & 1.43 & DQ & 74,551 & 128.64 & 6.89 \\
\hline $\mathrm{CH}$ & 58,327 & $1,268.26$ & 2.09 & DR & 75,309 & 206.49 & 3.88 \\
\hline CI & 58,367 & $1,290.38$ & 2.57 & DS & 76,283 & 198.65 & 4.32 \\
\hline $\mathrm{CJ}$ & 59,099 & $1,004.93$ & 2.03 & DT & 78,389 & 203.03 & 4.36 \\
\hline $\mathrm{CK}$ & 59,429 & 566.26 & 2.00 & DU & 79,631 & 99.01 & 5.70 \\
\hline $\mathrm{CL}$ & 59,964 & 260.18 & 2.52 & $\mathrm{DV}$ & 81,372 & 186.00 & 5.01 \\
\hline $\mathrm{CM}$ & 60,520 & 862.65 & 1.43 & DW & 83,919 & 188.19 & 4.37 \\
\hline
\end{tabular}

$\mathrm{CN}$

61,160

196.06

2.37 

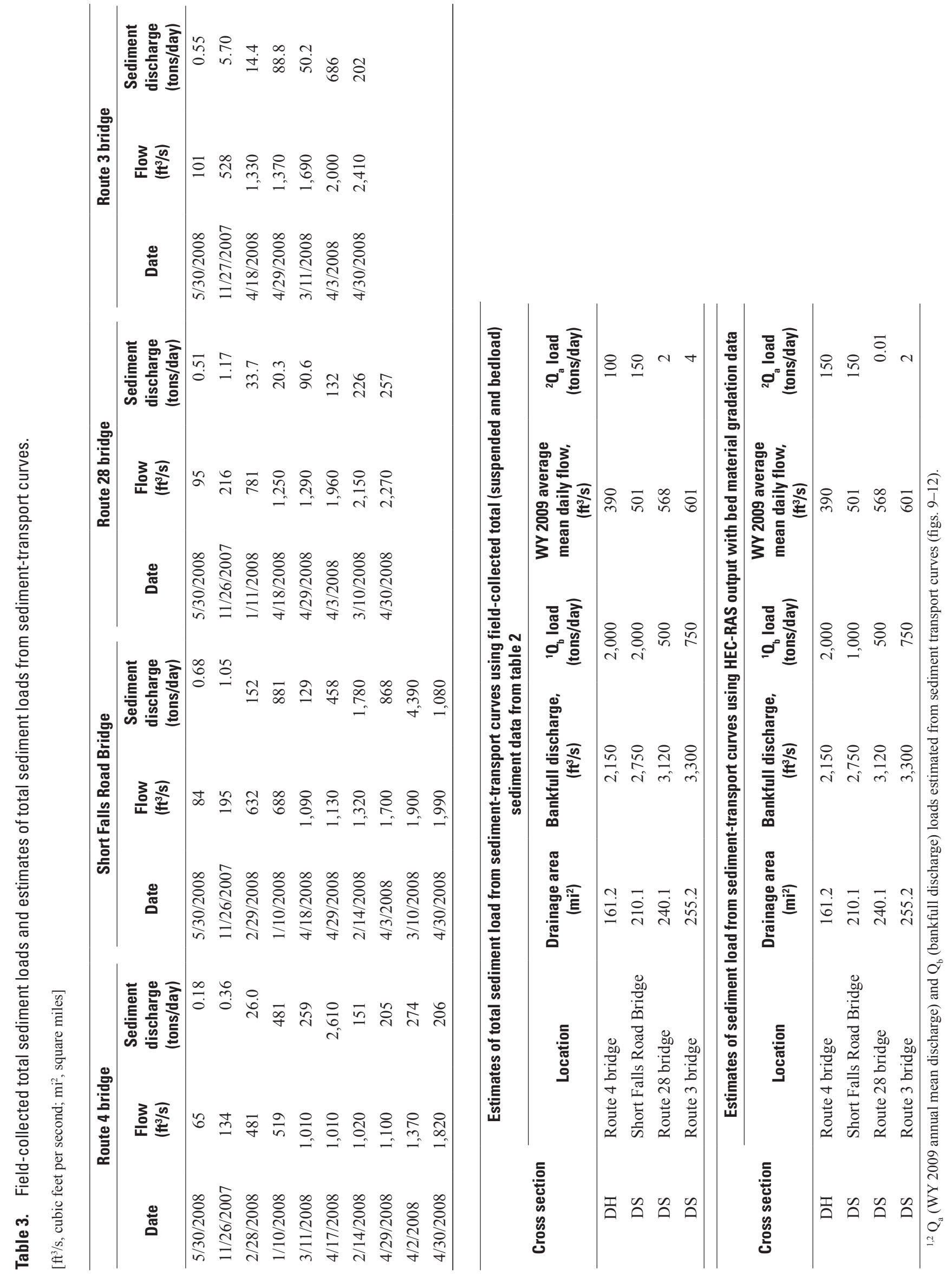
Streambed thalweg elevations as determined by the Laursen (Copeland) sediment-transport equation and the streambed thalweg elevations as surveyed after the 400-day period for the repeated survey of the Suncook River HECRAS model-calibration reach between the Buck Street Dams and the Short Falls Road Bridge are shown in table 4 and figure 8. Measured change compared to simulated change in streambed thalweg elevation at cross-section locations for the same calibration reach of the Suncook River are are shown in figure 9. In general, the simulated and measured streambed thalweg-elevation change for the calibration reach were in agreement. Cross section AZ is an exception, however, with a measured streambed thalweg elevation increase of $0.23 \mathrm{ft}$ and a simulated decrease of $3.43 \mathrm{ft}$. This location is at the confluence of Bear Brook with the Suncook River and indicates that, given additional flow from Bear Brook, a large amount of sediment would be transported from this location. The next downstream cross section at AY, however, had a much better agreement between measured and simulated streambed thalweg elevations with a measured streambed-elevation increase of $0.36 \mathrm{ft}$ and a simulated streambed-elevation change of $0.00 \mathrm{ft}$. It is important to note that a limitation of the onedimensional HEC-RAS model is that the model is unable to simulate a lateral distribution of sediment load along a cross section, and the simulation's calculation of how sediment transport is allocated is only an approximation.

Kendall's Tau rank correlation coefficient is a statistic used to measure the correlation between two measured quantities. Values of Kendall's Tau range between -1 and +1 , with a positive correlation indicating that the ranks of both variables increase together. A Kendall's Tau rank correlation coefficient of 0.4 was determined for the statistical agreement between the measured and simulated changes in streambedelevation data for the cross sections in the calibration reach. This indicates a moderate positive correlation, albeit not statistically significant, between the two datasets. The root mean square error (RMSE) is the square root of the variance of the residuals and is a good measure of the absolute fit of the model-predicted values to the observed data. Lower values of RMSE indicate a better fit. The RMSE for the two datasets was determined to be $1.2 \mathrm{ft}$.

\section{Flood-Generated Shear Stress and the Potential for Entrainment}

For fine sand and finer sizes of sediment (less than $0.25 \mathrm{~mm}$ ), moving particles will go directly into suspension following initiation of sediment motion. The corresponding critical shear stress, which equates applied forces in the direction of flow to resisting forces, is low, so that material of these sizes are frequently mobilized if cohesive effects are not large (ASCE, 2008). Fine to coarse sand (0.25 to $1 \mathrm{~mm}$ ) moves initially as bedload, with particles beginning to go into suspension at high shear stresses. Medium sand begins to move at boundary shear stresses of between 0.004 to $0.006 \mathrm{lb} / \mathrm{ft}^{2}(0.0002$ to 0.0003 kilopascals $(\mathrm{kPa})$ or 2 to 3 dynes per square centimeter $\left.\left(\mathrm{dy} / \mathrm{cm}^{2}\right)\right)$, and incipient suspension begins at boundary shear stress of 0.02 to $0.06 \mathrm{lb} / \mathrm{ft}^{2}\left(0.001\right.$ to $0.003 \mathrm{kPa}$ or 10 to $\left.30 \mathrm{dy} / \mathrm{cm}^{2}\right)$. Shear stresses of such magnitude can be reached during moderate river flows (ASCE, 2008). For fine gravel (up to $8 \mathrm{~mm}$ ), the critical shear stress is $0.094 \mathrm{lb} / \mathrm{ft}^{2}\left(0.0045 \mathrm{kPa}\right.$ or $\left.45 \mathrm{dy} / \mathrm{cm}^{2}\right)$, and particle movement is possible at shear stress greater than $1.15 \mathrm{lb} / \mathrm{ft}^{2}\left(0.055 \mathrm{kPa}\right.$ or $\left.550 \mathrm{dy} / \mathrm{cm}^{2}\right)$.

For a particle Reynolds number greater than approximately 200 , the dimensionless critical shear stress, or Shields parameter, becomes independent of the particle Reynolds number. Shields' studies showed that in gravel-bed channels of homogeneous sediment sizes and turbulent flow, the value of dimensionless critical shear stress is 0.06. Typical values of the constant Shields parameter vary between 0.03 and 0.06 for incipient motion. Based on the median $\left(d_{50}\right)$ sediment sizes in appendix 1, with most larger than $0.17 \mathrm{~mm}$, a value of 0.04 (for fine gravel) was used in the analysis but was compared to the more conservative Shields parameter value of 0.06 (table 5). The critical shear stress at each of the four bridge locations in this study was less than the average shear stress for the $d_{50}$ (see table 5). Based on mean daily shear stress from mean daily flow for the model period, sediment grains of the median $\left(d_{50}\right)$ size would be in motion. Information by specific site includes

- At Route 3 (fig. 3A), given the $d_{50}$ of $0.384 \mathrm{~mm}$ (medium sand), the critical shear stress is less than the streambed shear stress on 98 percent of the simulation days, thus indicating that the $d_{50}$ is in motion for 98 percent of the simulation days.

- At Route 28 (fig. 3B), given the $d_{50}$ of less than $0.0625 \mathrm{~mm}$ (coarse silt to very fine sand), the critical shear stress is less than the streambed shear stress on 73 percent of the simulation days, thus indicating that the $d_{50}$ is in motion for 73 percent of the simulation days.

- At Short Falls Road (fig. 3C), given the $d_{50}$ of $0.6875 \mathrm{~mm}$ (coarse sand), the critical shear stress is less than the streambed shear stress on every day of the model period, thus indicating that the median $\left(d_{50}\right)$ sediment size was in motion for 100 percent of the simulation days.

- At Route 4 (fig. 3D), given the $d_{50}$ of $26 \mathrm{~mm}$ (coarse gravel), the critical shear stress is less than the streambed shear stress on 95 percent of the simulation days, thus indicating that the $d_{50}$ is in motion for 95 percent of the simulation days. 
Table 4. Streambed thalweg elevations for the Suncook River, New Hampshire, study reach, surveyed $(2008,2009)$ and modeled (2009) using the Hydrologic Engineering Center River Analysis System (HEC-RAS) during a 400-day calibration, May 8, 2008-June 11, 2009.

[Location of cross sections AS-BT are shown in figure 3. ft, feet; NGVD 29, National Geodetic Vertical Datum of 1929; --, no data]

\begin{tabular}{|c|c|c|c|c|c|}
\hline \multirow{3}{*}{$\begin{array}{l}\text { Suncook River } \\
\text { cross section }\end{array}$} & \multirow{3}{*}{$\begin{array}{c}\text { Cumulative } \\
\text { distance upstream } 1 \\
\text { (ft) }\end{array}$} & \multicolumn{4}{|c|}{ Minimum channel elevations } \\
\hline & & \multicolumn{2}{|c|}{ Surveyed } & \multirow{2}{*}{$\begin{array}{c}\text { Modeled } \\
\begin{array}{l}\text { June 11, } 2009 \\
\text { (ft, NGVD 29) }\end{array}\end{array}$} & \multirow{2}{*}{$\begin{array}{c}\text { June 11, } 2009 \\
\text { difference } \\
\text { Surveyed vs. } \\
\text { modeled } \\
\text { (ft, NGVD 29) }\end{array}$} \\
\hline & & $\begin{array}{c}\text { May 8, } 2008 \\
\text { (ft, NGVD 29) }\end{array}$ & $\begin{array}{l}\text { June 11, } 2009 \\
\text { (ft, NGVD 29) }\end{array}$ & & \\
\hline AS & 29,216 & 280.40 & 280.08 & 279.41 & -0.67 \\
\hline-- & 29,285 & 280.93 & 280.50 & 281.20 & 0.70 \\
\hline AT & 29,347 & 279.21 & 280.25 & 279.36 & -0.89 \\
\hline $\mathrm{AU}$ & 29,600 & 279.10 & 279.24 & 279.11 & -0.13 \\
\hline AV & 30,715 & 279.32 & 280.08 & 278.74 & -1.34 \\
\hline AW & 31,747 & 276.97 & 277.01 & 276.96 & -0.05 \\
\hline $\mathrm{AX}$ & 33,142 & 276.47 & 278.04 & 276.46 & -1.58 \\
\hline AY & 34,227 & 279.64 & 280.00 & 279.64 & -0.36 \\
\hline $\mathrm{AZ}$ & 34,927 & 277.09 & 277.32 & 273.66 & -3.66 \\
\hline BA & 35,563 & 278.13 & 278.24 & 277.59 & -0.65 \\
\hline $\mathrm{BB}$ & 36,078 & 278.99 & 279.69 & 279.43 & -0.26 \\
\hline $\mathrm{BC}$ & 36,613 & 275.28 & 276.34 & 275.57 & -0.77 \\
\hline $\mathrm{BD}$ & 37,933 & 280.62 & 280.27 & 280.69 & 0.42 \\
\hline $\mathrm{BE}$ & 38,426 & 279.70 & 279.89 & 279.82 & -0.07 \\
\hline $\mathrm{BF}$ & 39,121 & 277.56 & 279.13 & 279.09 & -0.04 \\
\hline BG & 39,861 & 277.90 & 278.32 & 279.20 & 0.88 \\
\hline $\mathrm{BH}$ & 40,506 & 284.98 & 284.44 & 284.56 & 0.12 \\
\hline BI & 41,066 & 285.20 & 284.12 & 285.15 & 1.03 \\
\hline BJ & 41,899 & 278.65 & 276.65 & 278.78 & 2.13 \\
\hline BK & 43,019 & 284.04 & 283.34 & 284.49 & 1.15 \\
\hline BL & 43,741 & 279.70 & 282.71 & 280.45 & -2.26 \\
\hline $\mathrm{BM}$ & 44,821 & 285.93 & 285.24 & 285.76 & 0.52 \\
\hline $\mathrm{BN}$ & 45,161 & 286.48 & 284.70 & 286.03 & 1.33 \\
\hline $\mathrm{BO}$ & 45,724 & 278.21 & 280.04 & 279.03 & -1.01 \\
\hline $\mathrm{BP}$ & 46,356 & 286.15 & 286.19 & 285.89 & -0.30 \\
\hline BQ & 46,731 & 280.10 & 282.06 & 281.15 & -0.91 \\
\hline $\mathrm{BR}$ & 47,375 & 286.45 & 286.04 & 287.32 & 1.28 \\
\hline BS & 48,053 & 283.65 & 286.32 & 286.75 & 0.43 \\
\hline BT & 48,853 & 282.55 & 286.77 & 284.41 & -2.36 \\
\hline
\end{tabular}

\footnotetext{
${ }^{1}$ Feet upstream from confluence with Merrimack River $(1$ mile $=5,280 \mathrm{ft})$.
} 


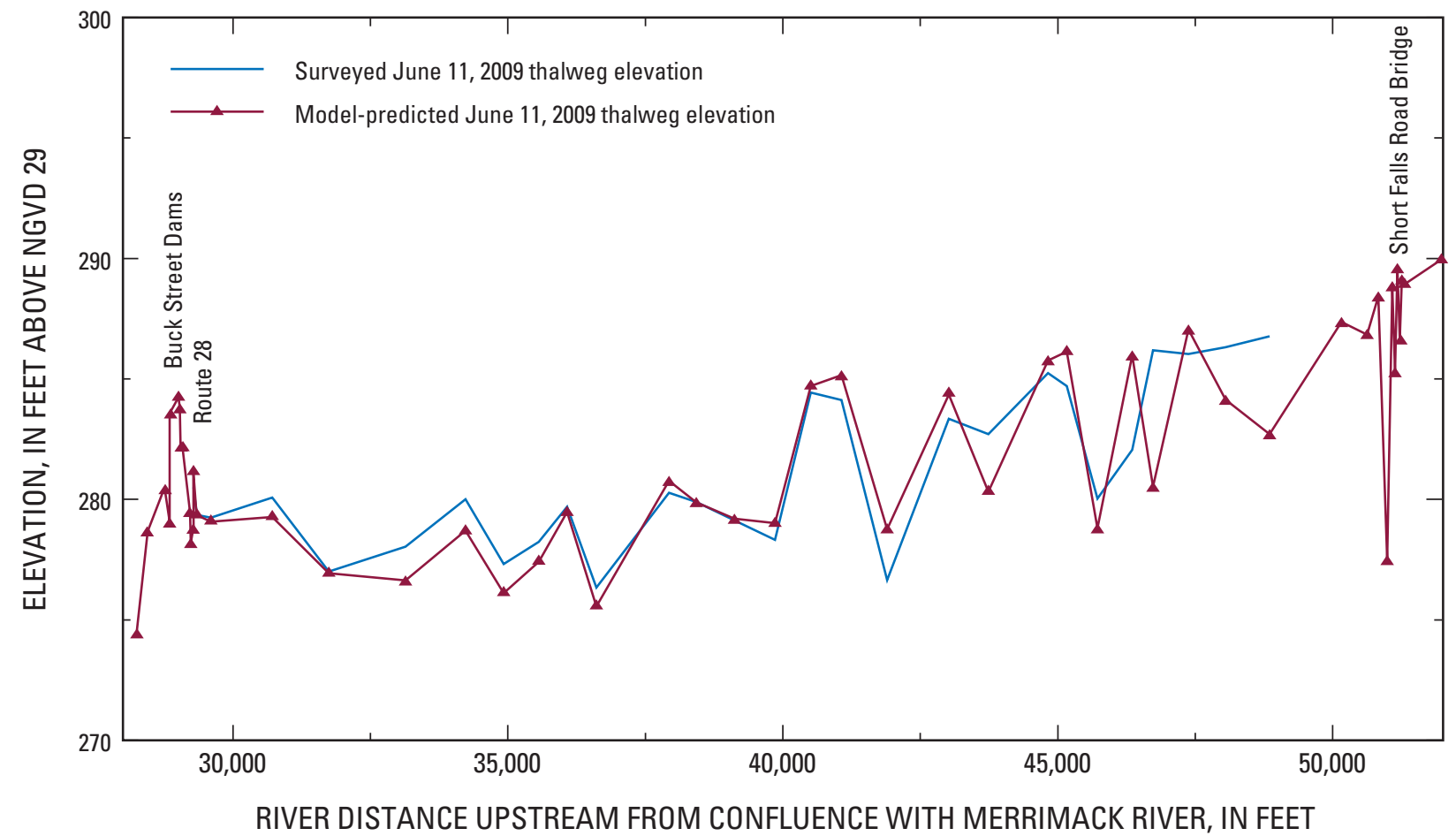

Figure 9. Suncook River streambed thalweg elevation between the Buck Street Dams and the Short Falls Road Bridge as surveyed on June 11, 2009, and as model-predicted using the Laursen (Copeland) sediment-transport function.

Table 5. Daily mean shear stress at four total sediment-load collection locations, Suncook River, Epsom to Allenstown, New Hampshire, during May 2008-end of water year 2009.

$\left[\%\right.$, percent; Shear stress values in pounds per square foot. Grain sizes in millimeters. $d_{50}$, median grain size; $d_{75}, 75$ th-percentile grain size. TC, critical shear stress]

\begin{tabular}{|c|c|c|c|c|}
\hline Bridge & Route 3 & Route 28 & Short Falls Road & Route 4 \\
\hline $\begin{array}{l}\% \text { days shear stress greater than } 0.004-0.006 \\
\text { (medium sand incipient motion) }\end{array}$ & $97-99$ & $25-32$ & 100 & 100 \\
\hline $\begin{array}{l}\% \text { days shear stress greater than } 0.02-06 \\
\text { (medium sand in suspension) }\end{array}$ & $76-90$ & $0.3-4$ & 100 & 100 \\
\hline Channel mean shear stress & 0.1875 & 0.0048 & 0.9517 & 1.259 \\
\hline Channel minimum shear stress & 0.0021 & 0.00003 & 0.2199 & 0.1139 \\
\hline Channel maximum shear stress & 1.47 & 0.08027 & 3.3451 & 5.2531 \\
\hline$d_{50}$ & 0.384 & $<0.0625$ & 0.6875 & 26 \\
\hline$d_{50}$ classification name & Medium sand & $\begin{array}{l}\text { Coarse silt to } \\
\text { very fine sand }\end{array}$ & Coarse sand & Coarse gravel \\
\hline Shields (parameter $=0.06$ ) critical shear stress & 0.008 & 0.0012 & 0.0142 & 0.5269 \\
\hline Shields (parameter $=0.06$ ) percentage of days $d_{50}$ in motion & 96 & 66 & 100 & 87 \\
\hline Shields $($ parameter $=0.04)$ critical shear stress & 0.0053 & 0.0008 & 0.0095 & 0.3513 \\
\hline Shields (parameter $=0.04$ ) percentage of days $d_{50}$ in motion & 98 & 73 & 100 & 95 \\
\hline$d_{75}$ & 0.5 & 0.125 & 1 & 121 \\
\hline$d_{75}$ classification name & $\begin{array}{l}\text { Medium to } \\
\text { coarse sand }\end{array}$ & $\begin{array}{l}\text { Very fine to } \\
\text { fine sand }\end{array}$ & $\begin{array}{l}\text { Coarse to very } \\
\text { coarse sand }\end{array}$ & Small cobbles \\
\hline Lane's (TC) critical shear stress & 0.0079 & 0.002 & 0.0158 & 1.905 \\
\hline Lane's (TC) percentage of days $d_{75}$ in motion & 96 & 51 & 100 & 13 \\
\hline
\end{tabular}


At the Route 28 bridge during the study simulation period, the modeled daily mean cross-section shear stress ranged from 0.00003 to $0.08 \mathrm{lb} / \mathrm{ft}^{2}$, with an average daily mean shear stress of $0.005 \mathrm{lb} / \mathrm{ft}^{2}$. On 68 percent of the days, the daily mean cross-section shear stress was less than 0.004 (medium sand not moving, but fine sand moving); on 75 percent of the days, it was less than 0.006 (coarse sand not moving, but medium and fine sand moving). On 96 percent of the days, the daily mean cross-section shear stress was less than 0.02 , and on 99.7 percent of the days the daily mean cross-section shear stress was less than 0.06 (table 5). On 25 to 32 percent of the days, the sediment smaller than or equal in size to medium sand was in motion. On approximately 0.3 to 4 percent of the days, the sediment smaller than or equal in size to medium sand was in suspension. On 73 percent of the simulation days, sediment smaller than or equal in size to very fine sand was in motion (table 5). These results are based on daily mean flows.

The shear stress analysis results for the Route 28 bridge are in contrast to those for the next upstream bridge at Short Falls Road, where sediment smaller than or equal in size to medium sand was in suspension and sediment smaller than or equal in size to coarse sand was in motion for 100 percent of the study simulation days. Much of the sediment passing the Short Falls Road Bridge had dropped out of suspension before reaching the Route 28 bridge. The analysis at the Route 28 bridge shows that for only 25 to 32 percent of the simulation days, sediment smaller than or equal in size to medium sand was in motion. This indicates that the reach between Short Falls Road Bridge and the downstream Route 28 bridge is retaining much of its coarser sediment load based on the streambed shear stress and the reach median grain sizes $\left(d_{50}\right)$ of a very fine gravel for all sediment-sampling locations below the avulsion and of a coarse sand at the Short Falls Road Bridge. Shear stress is a function of the energy gradient (or slope of the water surface) and hydraulic radius (approximated by the mean depth). An increase in either or both of these parameters will result in greater shear stress and an increased ability of the water in the channel to move sediment.

At the Short Falls Road and Route 4 bridges during the model period, the average daily mean cross-section shear stresses were 0.95 and $1.26 \mathrm{lb} / \mathrm{ft}^{2}$, respectively (table 5). The daily mean cross-section shear stress analysis at Route 4 indicates that sediment sizes smaller than or equal in size to coarse gravel were in motion for 95 percent of the simulation days, and medium sand was in suspension for 100 percent of the simulation days.

Although the Shields method has been widely used to determine initiation of motion, it does not account for the shielding of smaller particles by large particles. Because of this, a comparison was made to Lane's (1953) method (table 5). Lane observed that smaller particles were consistently shielded by larger ones, and that critical shear stress was related to the diameter of the particle. Lane felt that initiation of motion was better represented by a particle size in which only 25 percent of the particles were larger by weight $\left(d_{75}\right)$. Results for the bridge sampling locations were similar to

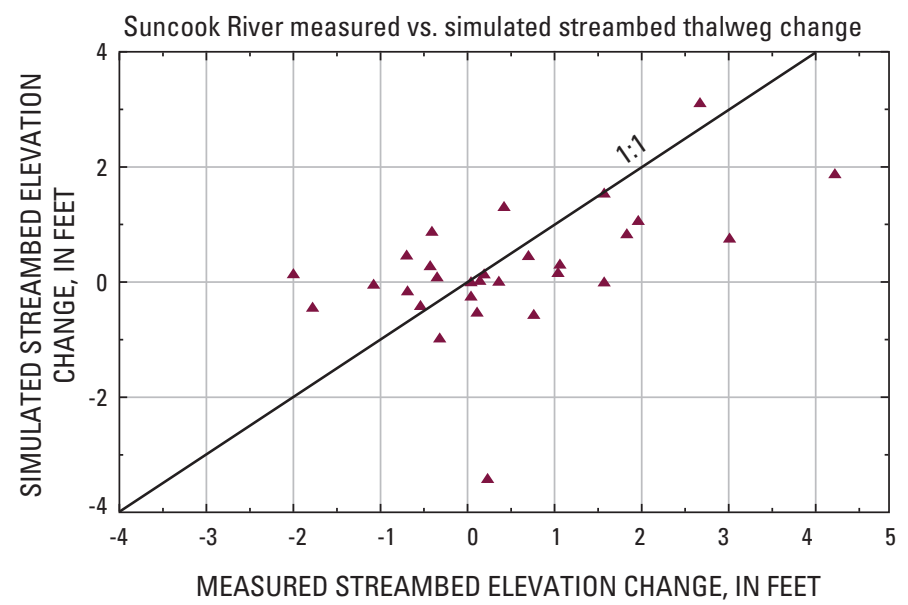

Figure 10. Measured vs. simulated streambed thalweg-elevation changes for the Suncook River from the Buck Street Dams to the Short Falls Road Bridge, Epsom and Pembroke, New Hampshire, June 11, 2009.

the more conservative Shields parameter value (0.06) results with the exception of the Route 4 bridge location. Critical shear stress calculated using Lane's method was 3.6 times greater than that calculated with a Shields parameter value of 0.06 , with the $d_{75}(121 \mathrm{~mm})$ being in motion for only 13 percent of the study-period days. This $d_{75}$ sediment size falls within the range of small cobbles (64 to $128 \mathrm{~mm}$ ) (ASCE, 2006) and indicates that sediment sizes in the cobble and boulder ranges are generally not in motion in this location.

The critical shear stress associated with sediment entrainment has been described as being, at best, a minimum estimate of the critical discharge because only a small area of the surface of the entire streambed or only a few particles of the $d_{50}$ size might be entrained by the critical discharge (Lisle and others, 1993). The complete mobilization of a size fraction, such as $d_{50}$, has been observed as occurring at roughly twice the shear necessary to initiate movement of individual particles of that size fraction (Wilcock and McArdell, 1993). The distribution of streambed shear stress for the 50- and 1-percent annual exceedence probability (2- and 100-year recurrenceintervals, respectively) floods and the critical streambed shear stress based on the $d_{50}$ particle size were plotted (figs. 10A-B) to show areas where, for either the 50- or 1-percent annual exceedence probability flood, little to no sediment is moving (as defined by: $\tau_{0}$ less than $\tau_{\mathrm{c}}$ ), some sediment is moving (as defined by: $\tau_{0}$ greater than $\tau_{\mathrm{c}}$ and $\tau_{0}$ less than $2 \tau_{\mathrm{c}}$ ), and much sediment is moving (as defined by: $\tau_{0}$ greater than $2 \tau_{\mathrm{c}}$ ); where $\tau_{0}$ is the mean boundary shear stress and $\tau_{\mathrm{c}}$ is the critical shear stress. 
Figures $11 \mathrm{~A}$ and $\mathrm{B}$ show that, in general, there is much (as defined by: $\tau_{0}$ greater than $2 \tau_{\mathrm{c}}$ ) sediment moving for recurrence-interval floods greater than the 50-percent annual exceedence probability flood (based on $d_{50}$ ). In figure $11 \mathrm{~A}$ (table 6$)$, the reach (2,315 ft in length) from approximately $90 \mathrm{ft}$ downstream of the Buck Street Dams to cross section AK has some (as defined by: $\tau_{0}$ greater than $\tau_{\mathrm{c}}$ and $\tau_{0}$ less than $2 \tau_{c}$ ) sediment moving for the 100 -year flood, and little to no (as defined by: $\tau_{0}$ less than $\tau_{\mathrm{c}}$ ) sediment moving for the 2-year flood. In figure 11B (table 6), the reach (1,091 ft in length) between cross sections CK and CM (located adjacent to Round Pond) has some to no sediment moving for the 2-year flood. The reach $(4,651 \mathrm{ft}$ in length) between cross sections CM and $\mathrm{CD}$ (downstream of the flood chute at the large meander bends to adjacent to Round Pond) has some (as defined by: $\tau_{0}$ greater than $\tau_{\mathrm{c}}$ and $\tau_{0}$ less than $2 \tau_{\mathrm{c}}$ ) sediment moving for the 100-year flood (flow is in channel and on overbanks). The reach (2,797 ft in length) between cross sections DE and CT (new reach through the former sand pit) has some (as defined by: $\tau_{0}$ greater than $\tau_{\mathrm{c}}$ and $\tau_{0}$ less than $2 \tau_{\mathrm{c}}$ ) sediment moving for the 2 -year flood. The 584-foot reach between cross sections DE and DC (upstream of the avulsion) has some (as defined by: $\tau_{0}$ greater than $\tau_{\mathrm{c}}$ and $\tau_{0}$ less than $2 \tau_{\mathrm{c}}$ ) sediment movement for the 100-year flood.

The variability in potential for entrainment is important because sediment entrained at one cross section may be unable to move at a cross section farther downstream, resulting in deposition and possibly aggradation over a period of time. The potential for aggradation in the Suncook River is greatest in the reach downstream of the former sand pit-from adjacent to Round Pond to downstream of the flood chute, at the large meander bends (cross sections CA to CM), and from downstream of the Short Falls Road bridge to approximately $3,800 \mathrm{ft}$ upstream of the Route 28 bridge.

\section{Model and Field-Data Sediment-Transport Curves}

The HEC-RAS sediment-transport model requires analyses of data on grain size for use with empirical equations in order to estimate total sediment transport, among other parameters. Total-sediment-transport curves (figs. 12A-D) were developed from total-sediment-load data (suspended load plus bedload) collected in the field at four bridge locations along the Suncook River (table 3); and from model-simulated total sediment loads based on field-collected streambed-gradation data. These curves show mean daily streamflow plotted against mean daily total-sediment load; they were created using fieldmeasured flow data, field-collected total-sediment data, and model output of total-sediment load (based on mean daily flow data from May 8, 2008 through the end of WY 2009). The field-collected streambed-gradation data were input into the model and generated sediment-load output estimates that were compared with field-collected total-sediment load data to calibrate and to verify the sediment-transport model.
Scatterplots of logarithms of these data tend to plot as linear patterns. The sediment loads (table 3 ) at the Route 3 bridge (fig. 12A) and Route 28 bridge (fig. 12B) are similar for the mean daily flow. Although the Route 4 bridge (fig. 12D) has a greater sediment discharge for a given flow than the Route 3 and Route 28 bridges, the data for the Route 4 bridge sediment-discharge curve are similar in trend to the data from both downstream sites. The Short Falls Road Bridge has a much greater sediment discharge for a given flow than any of the other three sites. The largest source of sediment for the study reach is the area of the sand pit and Leighton Brook (fig. 2) downstream of the avulsion, and most of this sediment load is being deposited in the reach between the sand-pit area and the Route 28/Buck Street Dams, a reach distance of approximately $7.0 \mathrm{mi}$.

These sediment-transport curves include the values of the bankfull discharge $(Q b)$, which has been approximated as a 1.8-year recurrence-interval discharge, and of the annual mean discharge $(Q a)$. Both these values have been adjusted for drainage area for each of the four locations at which data were collected.

Differences between observed and predicted sediment discharge can be seen for flows below 600 to $800 \mathrm{ft}^{3} / \mathrm{s}$ in the sediment-transport curves (figs. 12A-D) for the four total-load collection sites. To aid in validating the sediment-transport model, estimates of the field-collected total sediment load were compared with estimates of the model-output total sediment load, which were determined using the bed-material gradation data. Estimated sediment discharge (in tons per day) for the field-collected total sediment load deviates from that for the modeled bed-material dataset for flows below 600 to $800 \mathrm{ft}^{3} / \mathrm{s}$. Downstream of the Short Falls Road Bridge, at Route 28 and Route 3, field-collected total sediment-load data yield higher estimates of sediment discharge for flows less than 600 to $800 \mathrm{ft}^{3} / \mathrm{s}$ than does the sediment-transport model using bed-material gradation data. At the Short Falls Road Bridge and upstream at Route 4, however, field-collected data on total sediment load yielded lower estimates of sediment discharge for flows less than 600 to $800 \mathrm{ft}^{3} / \mathrm{s}$ than the sediment-transport model using bed-material gradation data.

The sediment-transport curve determined at the Route 28 bridge (fig. 11B) indicates that, based on sediment-gradation values obtained in the field and from simulation results, the volume of sediment transport (at flows less than $400 \mathrm{ft}^{3} / \mathrm{s}$ ) is either too little for the model to determine, or sediment is settling out of suspension (less than 0.01 tons per day). Field-collected total-sediment loads at discharges less than $400 \mathrm{ft}^{3} / \mathrm{s}$ are likely greater than model-predicted total-sediment loads due to the large volume of fine silt and sediment on the overbanks that washes into the river during precipitation events. These sediment data were subsequently field-collected as suspended sediment. In the sediment-transport curve for Route 28, the sediment-transport model deviates from the field data at flows less than approximately $800 \mathrm{ft}^{3} / \mathrm{s}$ in that the model predicts a much lower sediment discharge for flows less than $800 \mathrm{ft}^{3} / \mathrm{s}$. It is possible that the sediment data entered 


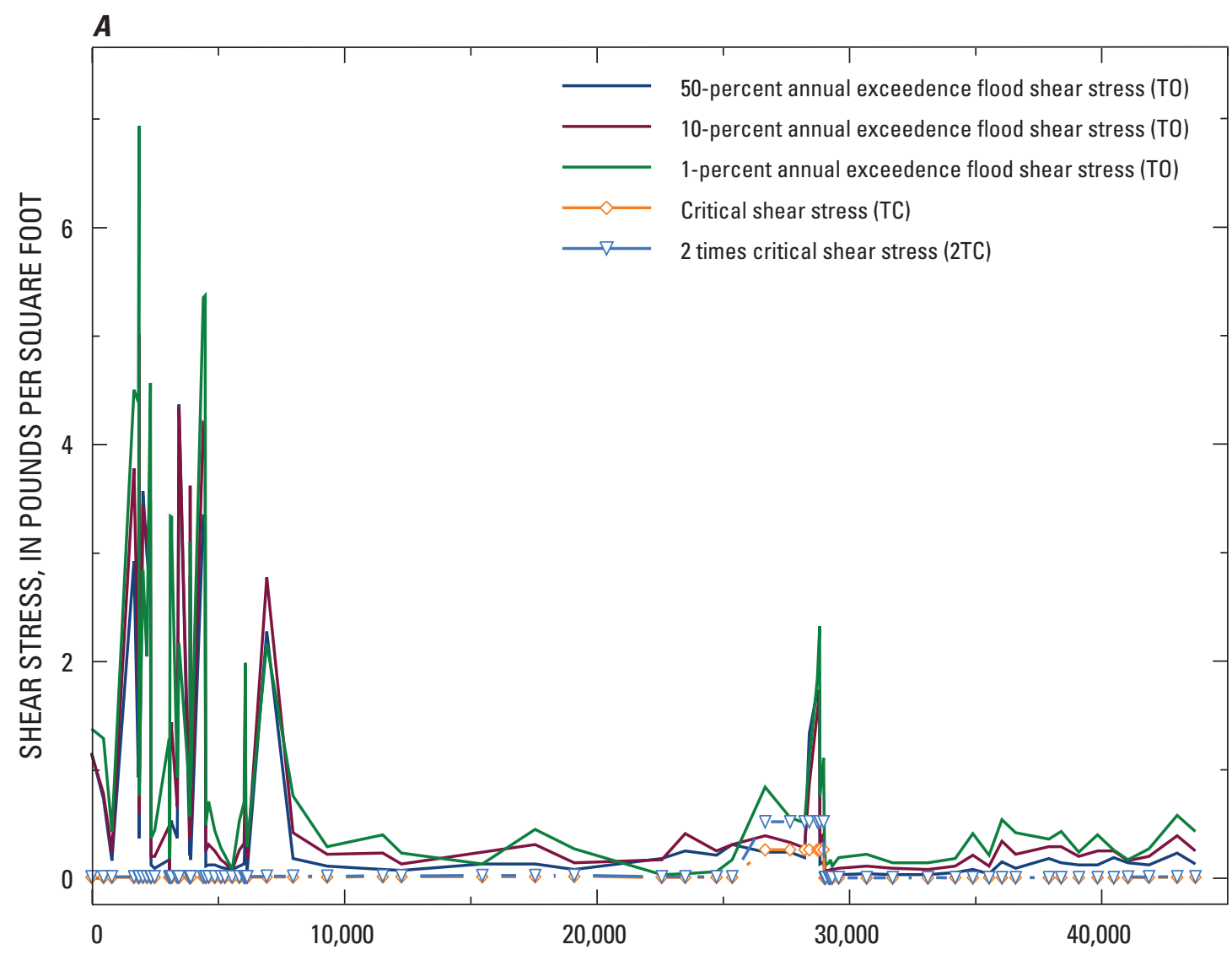

Figure 11A. Distribution of streambed shear stress in the Suncook River for the 50-, 10and 1-percent annual exceedence probability floods, and of critical streambed shear stress based on the $d_{50}$ (cross sections $A$ to $B L$ ).
Figure 11B. Distribution of streambed shear stress in the Suncook River for the 50-, 10and 1-percent annual exceedence probability flood, and of critical streambed shear stress based on the $d_{50}$ (cross sections $B L$ to $D W$ ).

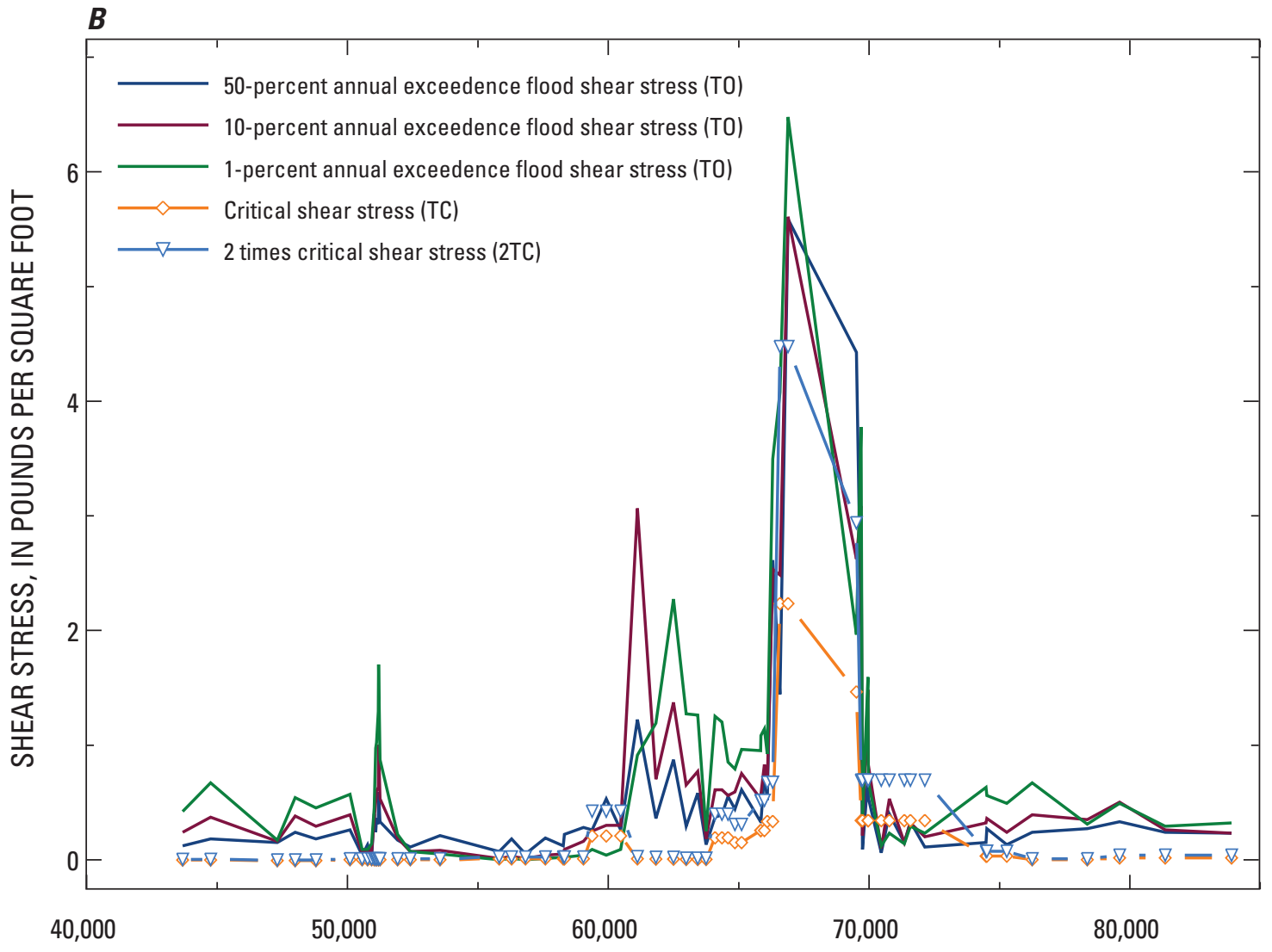


Table 6. Distribution of streambed shear stress in the Suncook River for the 50-, 10- and 1-percent annual exceedence probability flood.

$\left[\mathrm{ft}\right.$, feet; $\mathrm{lb} / \mathrm{ft}^{2}$, pounds per square feet $]$

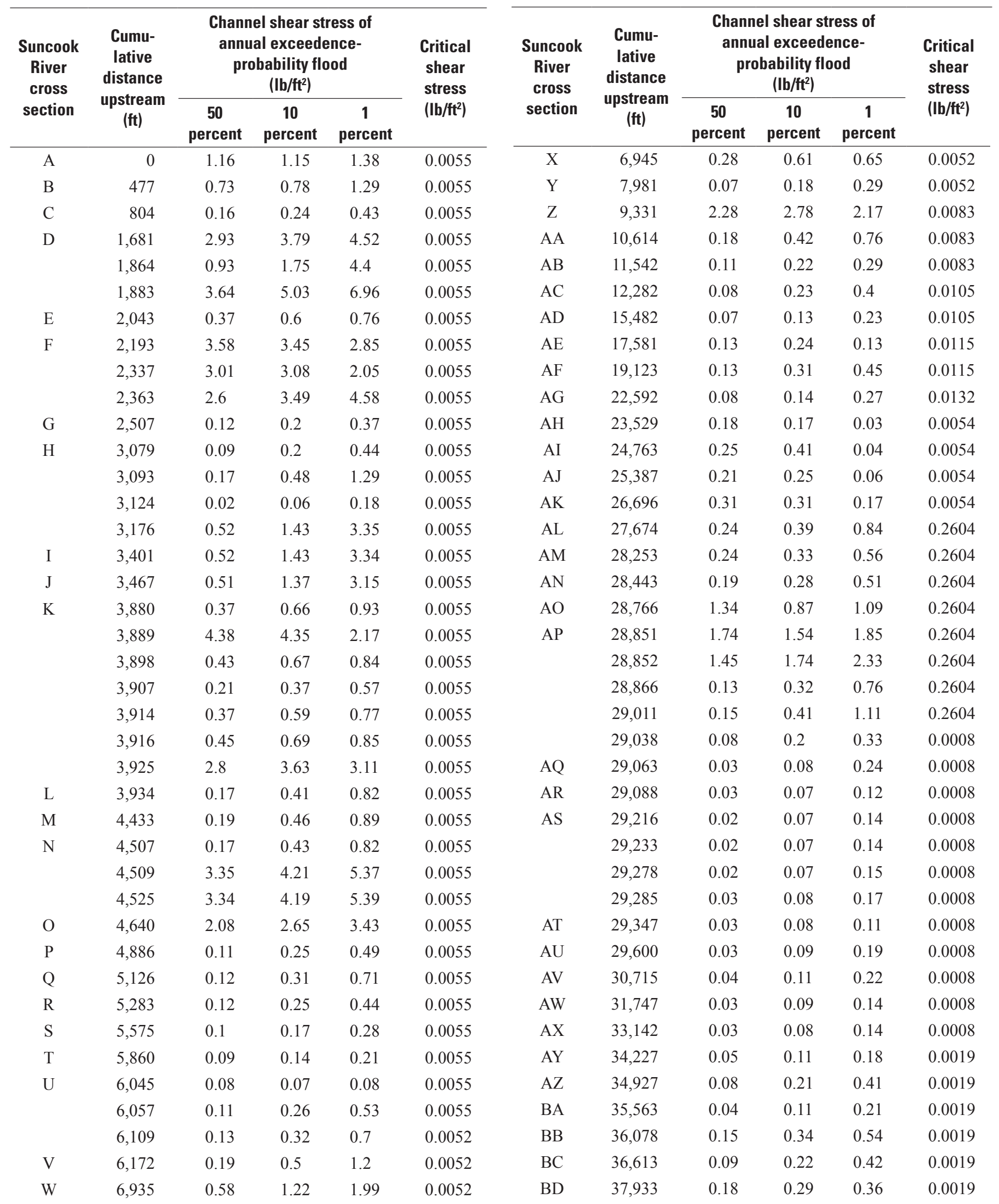


Table 6. Distribution of streambed shear stress in the Suncook River for the 50-, 10- and 1-percent annual exceedence probability flood.-Continued

[ft, feet; $1 \mathrm{~b} / \mathrm{ft}^{2}$, pounds per square feet $]$

\begin{tabular}{|c|c|c|c|c|c|c|c|c|c|c|c|}
\hline \multirow{2}{*}{$\begin{array}{c}\text { Suncook } \\
\text { River } \\
\text { cross } \\
\text { section }\end{array}$} & \multirow{2}{*}{$\begin{array}{l}\text { Cumu- } \\
\text { lative } \\
\text { distance } \\
\text { upstream } \\
\text { (ft) }\end{array}$} & \multicolumn{3}{|c|}{$\begin{array}{l}\text { Channel shear stress of } \\
\text { annual exceedence- } \\
\text { probability flood } \\
\left(\mathrm{lb} / \mathrm{ft}^{2}\right)\end{array}$} & \multirow{2}{*}{$\begin{array}{c}\text { Critical } \\
\text { shear } \\
\text { stress } \\
\left(\mathrm{Ib} / \mathrm{ft}^{2}\right)\end{array}$} & \multirow{2}{*}{$\begin{array}{c}\text { Suncook } \\
\text { River } \\
\text { cross } \\
\text { section }\end{array}$} & \multirow{2}{*}{$\begin{array}{l}\text { Cumu- } \\
\text { lative } \\
\text { distance } \\
\text { upstream } \\
\text { (ft) }\end{array}$} & \multicolumn{3}{|c|}{$\begin{array}{l}\text { Channel shear stress of } \\
\text { annual exceedence- } \\
\text { probability flood } \\
\left(\mathrm{lb} / \mathrm{ft}^{2}\right)\end{array}$} & \multirow{2}{*}{$\begin{array}{c}\text { Critical } \\
\text { shear } \\
\text { stress } \\
\left(\text { Ib/ft }^{2}\right)\end{array}$} \\
\hline & & $\begin{array}{c}50 \\
\text { percent }\end{array}$ & $\begin{array}{c}10 \\
\text { percent }\end{array}$ & $\begin{array}{c}1 \\
\text { percent }\end{array}$ & & & & $\begin{array}{c}50 \\
\text { percent }\end{array}$ & $\begin{array}{c}10 \\
\text { percent }\end{array}$ & $\begin{array}{c}1 \\
\text { percent }\end{array}$ & \\
\hline $\mathrm{BE}$ & 38,426 & 0.14 & 0.29 & 0.43 & 0.0019 & $\mathrm{CN}$ & 61,160 & 1.23 & 3.07 & 0.92 & 0.0180 \\
\hline BG & 39,861 & 0.12 & 0.25 & 0.4 & 0.0019 & $\mathrm{CP}$ & 62,547 & 0.88 & 1.38 & 2.28 & 0.0158 \\
\hline $\mathrm{BH}$ & 40,506 & 0.19 & 0.25 & 0.26 & 0.0019 & CQ & 63,035 & 0.3 & 0.66 & 1.28 & 0.0115 \\
\hline $\mathrm{BI}$ & 41,066 & 0.14 & 0.16 & 0.17 & 0.0041 & $\mathrm{CR}$ & 63,475 & 0.59 & 0.78 & 1.27 & 0.0115 \\
\hline BJ & 41,899 & 0.12 & 0.2 & 0.27 & 0.0062 & $\mathrm{CS}$ & 63,795 & 0.14 & 0.19 & 0.26 & 0.0115 \\
\hline BK & 43,019 & 0.23 & 0.39 & 0.58 & 0.0062 & $\mathrm{CT}$ & 64,132 & 0.38 & 0.62 & 1.26 & 0.2027 \\
\hline BO & 45,724 & 0.09 & 0.18 & 0.31 & 0.0062 & $\mathrm{CX}$ & 65,150 & 0.62 & 0.76 & 0.97 & 0.1588 \\
\hline BP & 46,356 & 0.23 & 0.42 & 0.74 & 0.0062 & $\mathrm{CY}$ & 65,883 & 0.34 & 0.54 & 0.96 & 0.2635 \\
\hline BQ & 46,731 & 0.15 & 0.25 & 0.39 & 0.0031 & $\mathrm{CZ}$ & 65,893 & 0.34 & 0.58 & 1.09 & 0.2635 \\
\hline BR & 47,375 & 0.16 & 0.17 & 0.18 & 0.0031 & DA & 66,029 & 0.76 & 0.84 & 1.15 & 0.2635 \\
\hline $\mathrm{BS}$ & 48,053 & 0.25 & 0.39 & 0.55 & 0.0031 & $\mathrm{DB}$ & 66,140 & 0.53 & 0.68 & 0.93 & 0.3423 \\
\hline BT & 48,853 & 0.19 & 0.3 & 0.46 & 0.0031 & $\mathrm{DC}$ & 66,345 & 2.62 & 2.54 & 3.5 & 0.3423 \\
\hline $\mathrm{BU}$ & 50,158 & 0.27 & 0.4 & 0.58 & 0.0093 & $\mathrm{DD}$ & 66,627 & 1.45 & 2.49 & 4.08 & 2.2403 \\
\hline BV & 50,624 & 0.05 & 0.07 & 0.1 & 0.0093 & $\mathrm{DE}$ & 66,929 & 5.59 & 5.61 & 6.48 & 2.2403 \\
\hline BW & 50,829 & 0.14 & 0.09 & 0.1 & 0.0093 & DF & 67,651 & 0.71 & 1.29 & 2.38 & 2.2403 \\
\hline BY & 51,305 & 0.34 & 0.54 & 0.88 & 0.0095 & DJ & 70,008 & 0.55 & 0.84 & 0.69 & 0.3513 \\
\hline $\mathrm{BZ}$ & 51,975 & 0.18 & 0.2 & 0.23 & 0.0095 & DK & 70,501 & 0.07 & 0.11 & 0.13 & 0.3513 \\
\hline $\mathrm{CA}$ & 52,463 & 0.12 & 0.08 & 0.08 & 0.0095 & DL & 70,813 & 0.41 & 0.54 & 0.24 & 0.3513 \\
\hline $\mathrm{CB}$ & 53,600 & 0.22 & 0.09 & 0.06 & 0.0095 & DM & 71,389 & 0.16 & 0.16 & 0.15 & 0.3513 \\
\hline $\mathrm{CC}$ & 54,415 & 0.18 & 0.04 & 0.02 & 0.0095 & $\mathrm{DN}$ & 71,617 & 0.34 & 0.33 & 0.3 & 0.3513 \\
\hline $\mathrm{CD}$ & 55,869 & 0.08 & 0.02 & 0.01 & 0.0172 & DO & 72,166 & 0.12 & 0.21 & 0.24 & 0.3513 \\
\hline $\mathrm{CE}$ & 56,345 & 0.19 & 0.04 & 0.02 & 0.0172 & $\mathrm{DP}$ & 74,513 & 0.16 & 0.33 & 0.64 & 0.0419 \\
\hline $\mathrm{CF}$ & 56,880 & 0.06 & 0.02 & 0.01 & 0.0172 & DQ & 74,551 & 0.28 & 0.37 & 0.57 & 0.0419 \\
\hline $\mathrm{CG}$ & 57,636 & 0.2 & 0.05 & 0.02 & 0.0172 & DR & 75,309 & 0.14 & 0.25 & 0.5 & 0.0419 \\
\hline $\mathrm{CH}$ & 58,327 & 0.13 & 0.06 & 0.03 & 0.0172 & DS & 76,283 & 0.25 & 0.4 & 0.68 & 0.0090 \\
\hline $\mathrm{CI}$ & 58,367 & 0.23 & 0.1 & 0.03 & 0.0172 & DT & 78,389 & 0.28 & 0.36 & 0.32 & 0.0090 \\
\hline CJ & 59,099 & 0.29 & 0.17 & 0.05 & 0.0172 & $\mathrm{DU}$ & 79,631 & 0.34 & 0.51 & 0.5 & 0.0251 \\
\hline $\mathrm{CK}$ & 59,429 & 0.27 & 0.26 & 0.1 & 0.2162 & DV & 81,372 & 0.25 & 0.27 & 0.3 & 0.0251 \\
\hline $\mathrm{CL}$ & 59,964 & 0.54 & 0.31 & 0.05 & 0.2162 & DW & 83,919 & 0.24 & 0.24 & 0.33 & 0.0251 \\
\hline
\end{tabular}




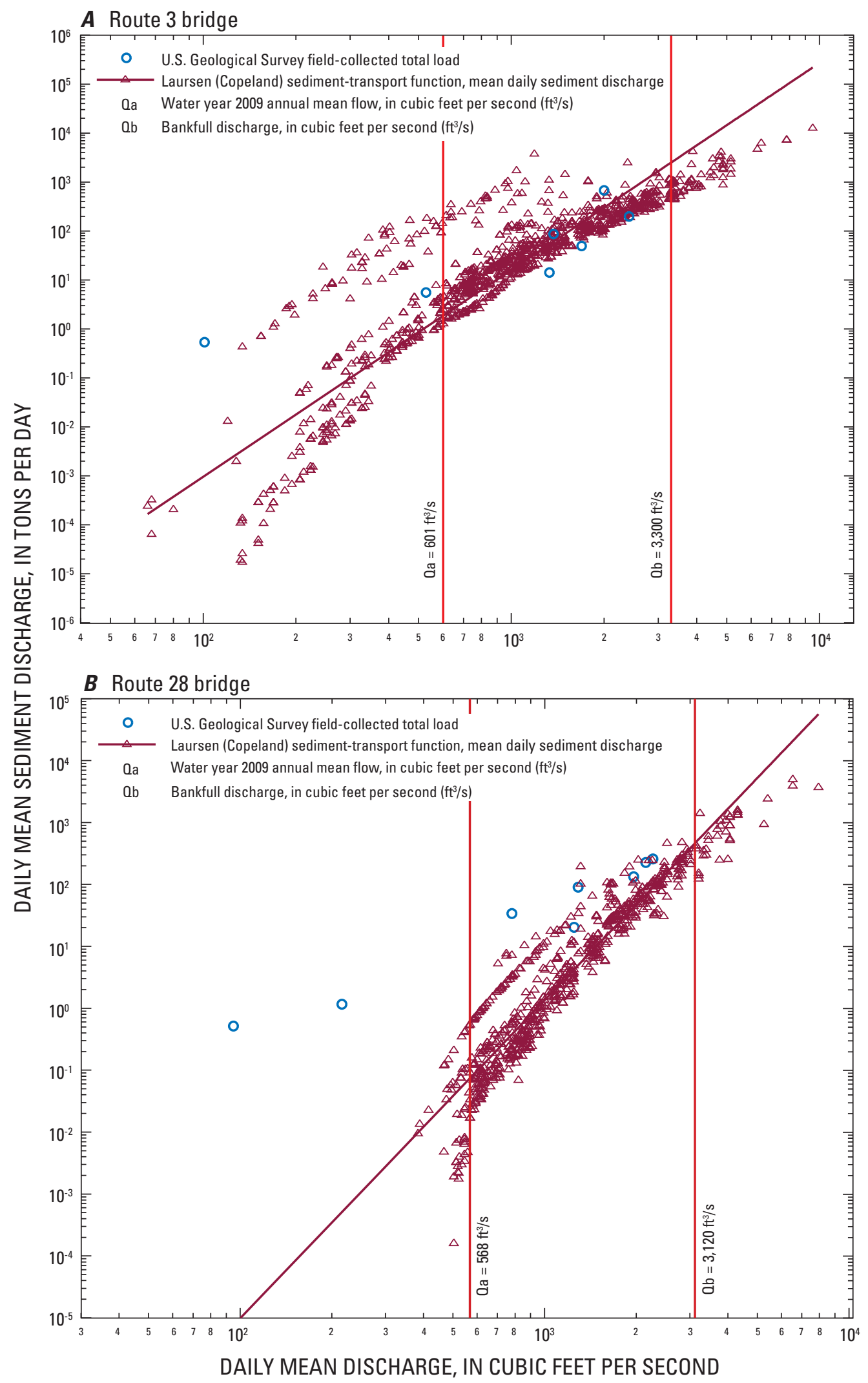

Figure 12A-B. Sediment-transport curve for Suncook River at $A$, Route 3 bridge, and $B$, Route 28 bridge. 
C Short Falls Road bridge

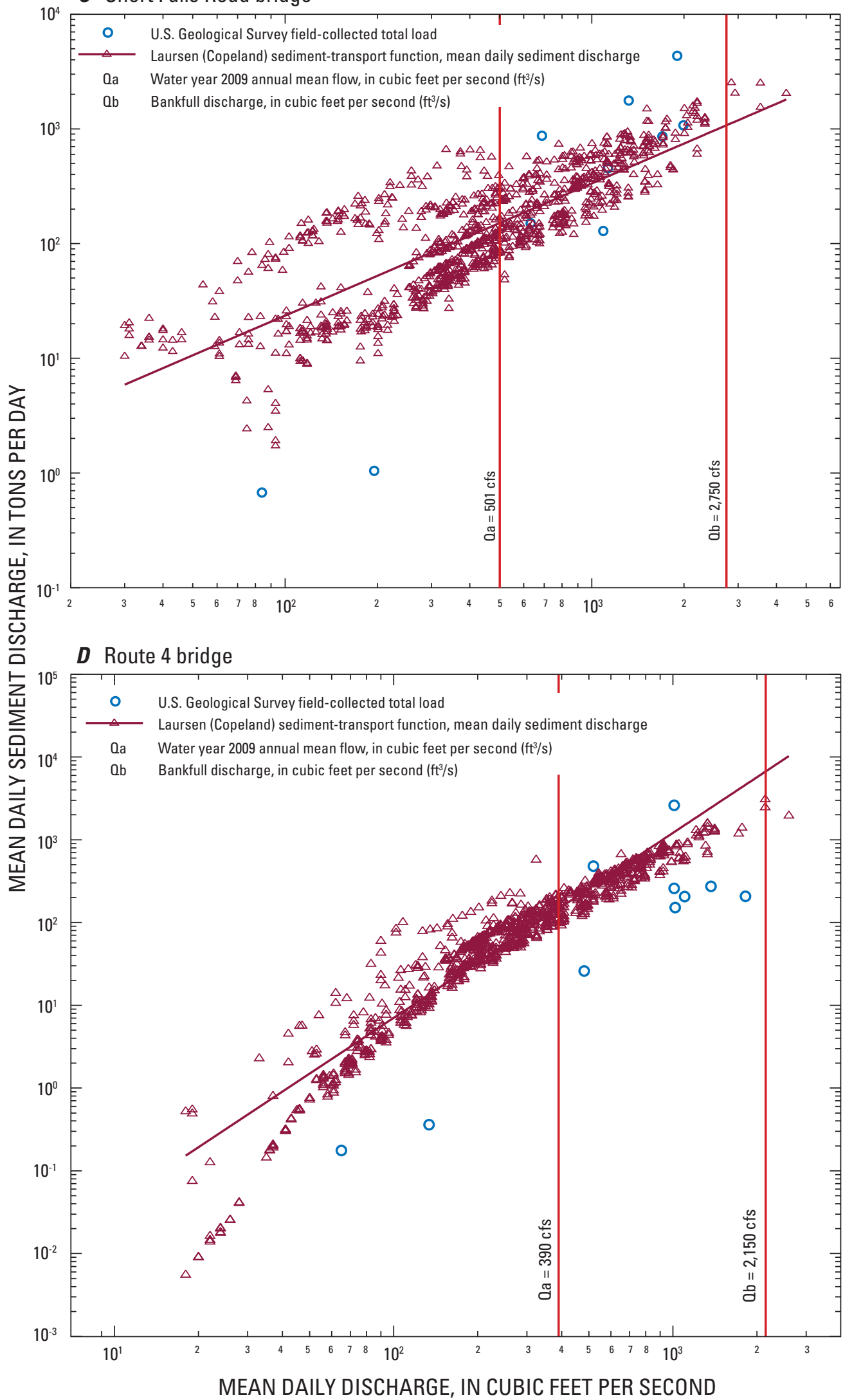

Figure 12C-D. Sediment-transport curve for Suncook River at $C$, Short Falls Road Bridge, and $D$, Route 4 bridge. 
into the model are based on gradation data for bed material that is coarser than that of the suspended and bedload field data, and that this difference in grain size, in turn, is due to the extensive aggradation in the reach from upstream of the Route 28 bridge to the Short Falls Road Bridge, both in the channel and on the overbanks. Bed material at the upstream and downstream faces of the Route 28 bridge does not consist of a high proportion of fine sand, silt and clay sediment; the lower weight density of the sediment and higher flow velocities at the bridge ensure that the fine sediment remains in suspension and is carried downstream of the bridge. This fine sediment in suspension was sampled on days that field data were collected. Much of the sediment generated by the avulsion appears to have settled between the Short Falls Road Bridge and the east and west Buck Street Dams, and some has passed over the dams. To a lesser degree, the same deviation in the field-collected total-load data in relation to the modeled bed-material data for sediment discharge at lower flows at the Route 28 bridge (fig. 12B) can also be seen at the Route 3 bridge (fig. 12A) downstream of the Route 28 bridge.

In the sediment-transport curve for the Short Falls Road Bridge (fig. 12C), the HEC-RAS sediment-transport model (using bed-material gradation) predicts a higher sediment discharge than the field-collected total-load data for flows less than $600 \mathrm{ft}^{3} / \mathrm{s}$. An explanation may be that the sediment data entered into the model are based on gradation data for bed material that is finer than the suspended and bedload material, possibly indicating a later change to a coarser gradation upstream of the Short Falls Road Bridge. At the downstream face of the Short Falls Road Bridge, the river widens abruptly. An abrupt decrease in flow velocities associated with this widening is a result of the increased cross-sectional flow area. Finer sediment therefore falls out of suspension downstream of the Short Falls Road Bridge, thereby strongly influencing the gradation of bed material. In addition, the field-collected data on bed material for the reach upstream of the Short Falls Road Bridge may not reflect the volume of fine silt and clay sediment on the overbanks and in the stream that is found in the reach downstream of the Short Falls Road Bridge. To a lesser degree, the same discrepancy between low flows and sediment discharge at the Short Falls Road Bridge (fig. 12C) can be seen at the Route 4 bridge upstream of the Short Falls Road Bridge (fig. 12D). At the Route 4 bridge, however, the modeled data on bed material show a finer gradation with higher sediment discharge for a given flow than do the fieldcollected data on total load, perhaps because the channel has much more cobble and gravel than the channel at the Short Falls Road Bridge downstream. These anomalies add to the uncertainties that field-collection activities provide for accurately representing suspended sediment and bedload sediment near the streambed.

\section{Simulating Sediment Transport to Investigate the Impact of Future Sediment Loads on Flood Flows}

The sediment model using the Laursen (Copeland) sediment-transport equation was used to determine sediment transport and streambed elevations for the end of WY 2010. Using channel geometry, mean daily flow and water-temperature data from WY 2009, the quasi-unsteady-state sedimenttransport model was run for WY 2010. The resultant cross sections were imported into a steady-state-flow model, which was then run to determine the effect of the altered channel bed on elevations for the 50-, 10-, 2-, 1-, and 0.2-percent annual exceedence probability floods. Although the HEC-RAS model uses data from the simulated quasi-unsteady flow to determine specific values for the streambed elevation, these values represent predicted averages for each stream reach.

Suncook River streambed-thalweg elevations from May 2008, Flood Insurance Studies (surveyed in 1976), and predicted by the model for end of WY 2010, are shown in figures $13 \mathrm{~A}-\mathrm{D}$. These thalweg elevations have been estimated between surveyed cross sections by straight-line interpolation. In general, it can be seen that the reach below the avulsion has aggraded, while the reach above the avulsion has degraded. The depths of aggradation and degradation can be approximated from these figures by comparing the lowest stream cross-section elevations (thalweg) from the 1978 Flood Insurance Study and the 2008 USGS surveyed elevations with the elevations predicted for the end of WY 2010, although other areas of the cross section may have a larger or smaller level of aggradation or degradation.

Changes in elevation (at each cross section) of the streambed thalwegs for the selected floods predicted by the model for the end of WY 2010 as compared with the streambed thalwegs surveyed in May 2008, and predicted by the steady-state modeled water surface using the May 2008 data (Flynn, 2010), are shown in table 7 (in back of report). The change in streambed thalweg (table 8) at all of the crosssection locations was a mean degradation of $0.46 \mathrm{ft}$ (median degradation of $0.57 \mathrm{ft}$ ). There was greater mean degradation (channel erosion) above the avulsion as compared to that below the avulsion for the model simulation period. The model simulation shows that for all cross-section locations, overall degradation resulted in the greatest effect for the higher annual exceedence probability (lower recurrence interval) floods (table 8) with a decreased mean flood elevation for the 50 -percent annual exceedence probability (2-year recurrence interval) flood of $0.39 \mathrm{ft}$ (median decrease of $0.01 \mathrm{ft}$ ).

The change in the streambed thalweg for the crosssection locations between the Short Falls Road Bridge and the Buck Street Dams for the May 2008 to the end of WY 2010 simulation period was a mean aggradation (net raising of streambed) of $0.88 \mathrm{ft}$ (median aggradation of $0.17 \mathrm{ft}$ ) (table 8). The simulation-period results show that this channel reach is continuing to fill with sediment, with the greatest effect of the sediment deposition on water-surface elevation occurring for the higher annual exceedence probability 


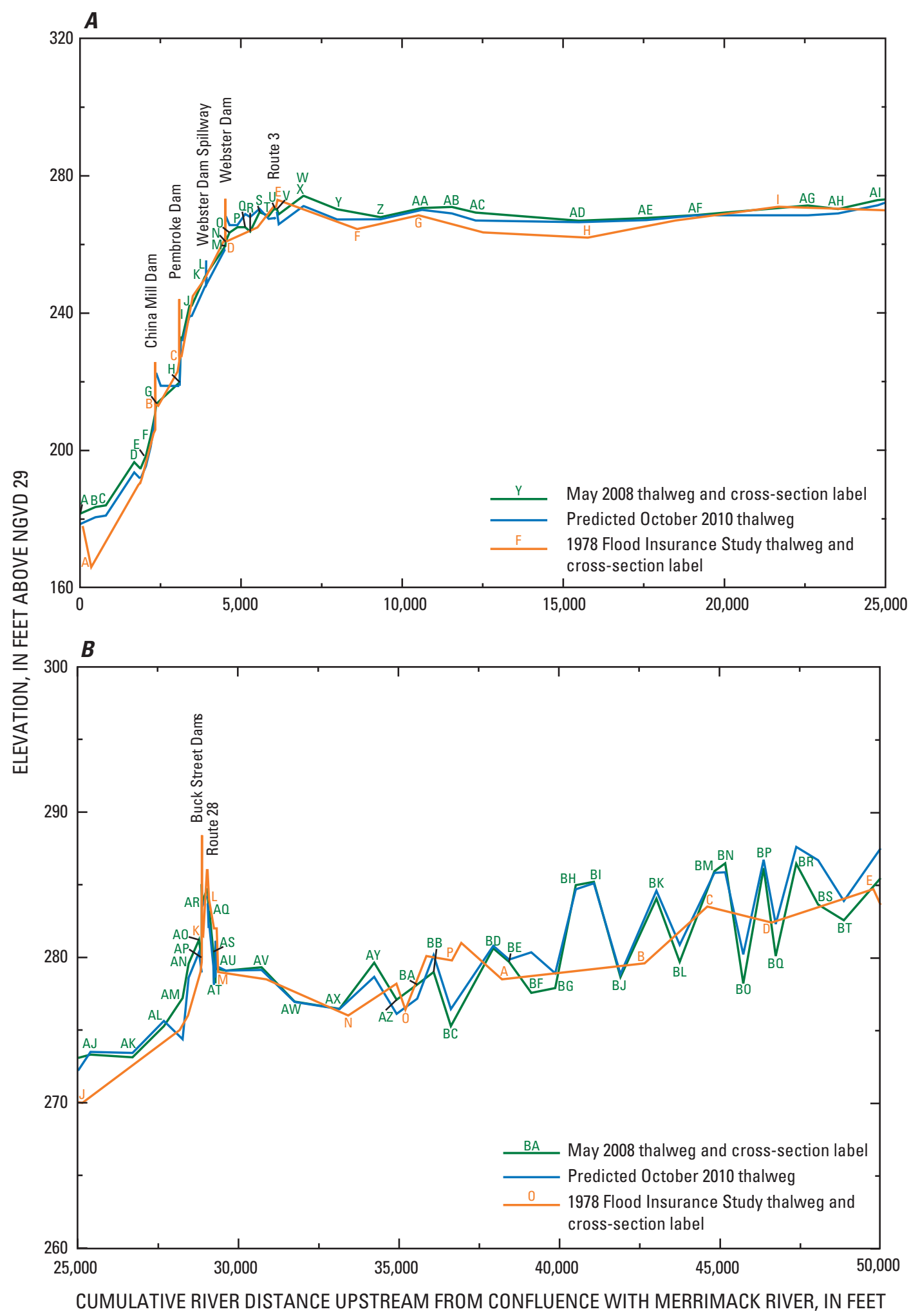

Figure 13A-B. Thalweg elevations of the Suncook River streambed from data published in May 2008 and in 1978 Flood Insurance Studies and from model predictions for end of water year 2010 in $A$, cross sections $A$ to $\mathrm{Al}$, and $B$, cross sections $\mathrm{AJ}$ to $\mathrm{BT}$. 


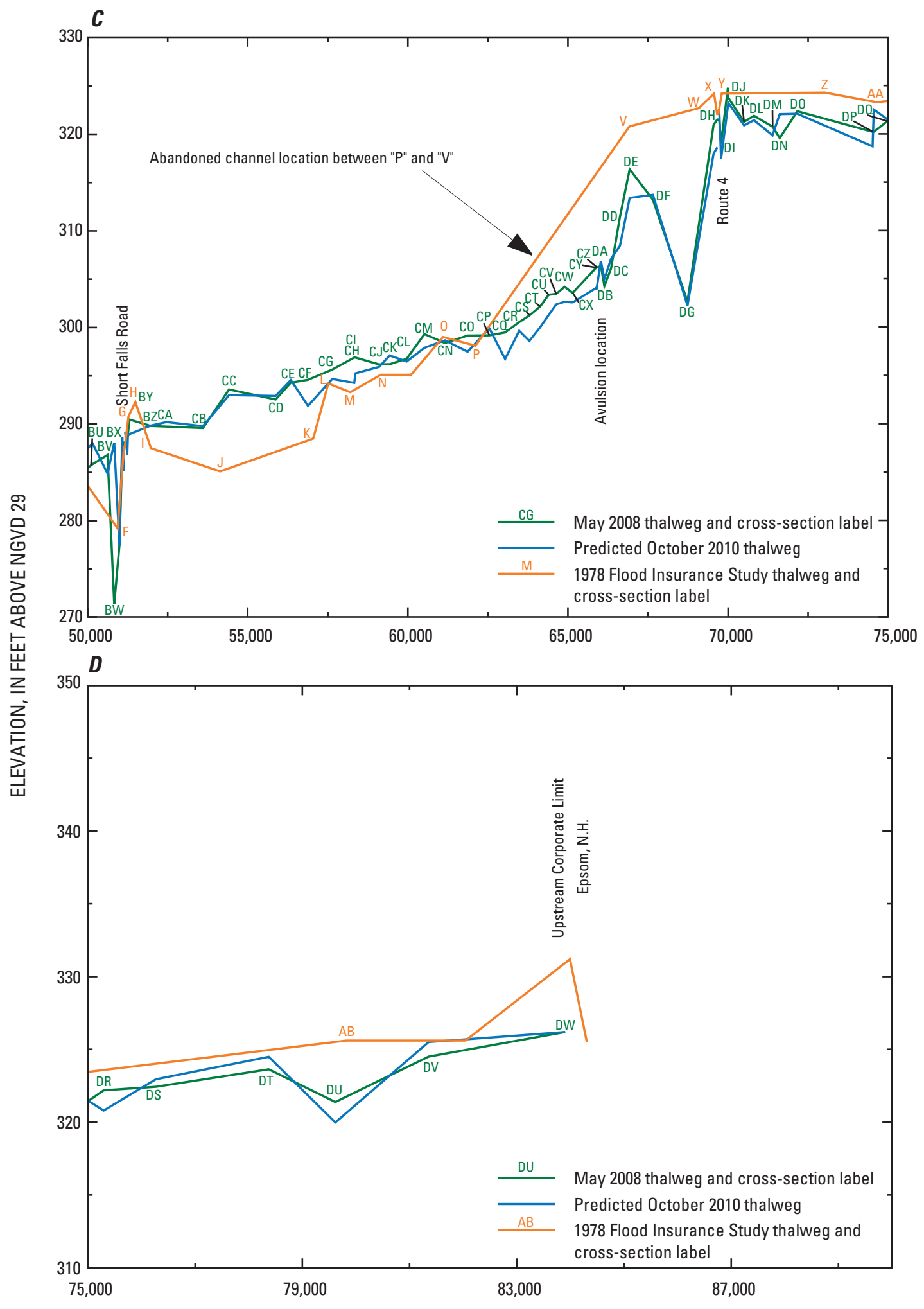

CUMULATIVE RIVER DISTANCE UPSTREAM FROM CONFLUENCE WITH MERRIMACK RIVER, IN FEET

Figure 13C-D. Thalweg elevations of the Suncook River streambed from data published in May 2008 and in 1978 Flood Insurance Studies and from model predictions for end of water year 2010 in C, cross sections BU to $\mathrm{DQ}$, and $D$, cross sections DR to DW. 
Table 8. Hydrologic Engineering Center-River Analysis System (HEC-RAS)-predicted changes in water-surface elevation and in thalweg elevation above and below the avulsion and between Short Falls Road and Buck Street Dams from 2008 through the end of water year 2010.

[XS, cross section; ft, feet; \%, percent]

\begin{tabular}{ccccccccc}
\hline & $\begin{array}{c}\text { All XS } \\
\text { mean } \\
\text { change } \\
\text { (ft) }\end{array}$ & $\begin{array}{c}\text { All XS } \\
\text { median } \\
\text { change } \\
\text { (ft) }\end{array}$ & $\begin{array}{c}\text { Above } \\
\text { avulsion } \\
\text { mean } \\
\text { change } \\
\text { (ft) }\end{array}$ & $\begin{array}{c}\text { Above } \\
\text { avulsion } \\
\text { median } \\
\text { change } \\
\text { (ft) }\end{array}$ & $\begin{array}{c}\text { Below } \\
\text { avulsion } \\
\text { mean } \\
\text { change } \\
\text { (ft) }\end{array}$ & $\begin{array}{c}\text { Below } \\
\text { avulsion } \\
\text { median } \\
\text { change } \\
\text { (ft) }\end{array}$ & $\begin{array}{c}\text { Short Falls } \\
\text { Road to Buck } \\
\text { Street Dams } \\
\text { mean change } \\
\text { (ft) }\end{array}$ & $\begin{array}{c}\text { Short Falls } \\
\text { Road to Buck } \\
\text { Street Dams } \\
\text { median change } \\
\text { (ft) }\end{array}$ \\
\hline $\begin{array}{c}\text { Thalweg } \\
\begin{array}{c}\text { Annual exceedance } \\
\text { probability flood (\%) }\end{array}\end{array}$ & -0.46 & -0.57 & -0.49 & -0.39 & -0.45 & -0.62 & 0.88 & 0.17 \\
\hline $\mathbf{5 0}$ & & & & & & & & \\
\\
$\mathbf{1 0}$ & -0.39 & -0.01 & -0.41 & -0.10 & -0.38 & -0.01 & 0.20 & 0.14 \\
$\mathbf{2}$ & -0.28 & -0.03 & -0.30 & -0.17 & -0.28 & -0.02 & 0.17 & 0.16 \\
$\mathbf{1}$ & -0.19 & -0.06 & -0.30 & -0.22 & -0.17 & -0.02 & 0.12 & 0.13 \\
$\mathbf{0 . 2}$ & -0.18 & -0.14 & -0.25 & -0.15 & -0.17 & -0.10 & 0.04 & 0.05 \\
\hline
\end{tabular}

(lower recurrence interval) floods. For the 50-percent annual exceedence probability (2-year recurrence interval) flood, the simulated mean aggradation of $0.88 \mathrm{ft}$ (median aggradation of $0.17 \mathrm{ft}$ ) resulted in an increased mean flood elevation of $0.20 \mathrm{ft}$ (median increase of $0.14 \mathrm{ft}$ ).

The mean change to the water-surface elevations at all the cross sections (table 8 ) was a lowering by $0.39 \mathrm{ft}$ (median of $0.01 \mathrm{ft}$ ) of the 50 -percent annual exceedence probability (2-year recurrence interval) flood, $0.28 \mathrm{ft}$ (median of $0.03 \mathrm{ft}$ ) for the 10-percent annual exceedence probability (10-year recurrence interval) flood, $0.19 \mathrm{ft}$ (median of $0.06 \mathrm{ft}$ ) for the 2-percent annual exceedence probability (50-year recurrence interval) flood, $0.18 \mathrm{ft}$ (median of $0.14 \mathrm{ft}$ ) for the 1-percent annual exceedence probability (100-year recurrence interval) flood, and $0.16 \mathrm{ft}$ (median of $0.14 \mathrm{ft}$ ) for the 0.2 -percent annual exceedence probability (500-year recurrence interval) flood.

\section{Electrical Resistivity Data}

Preliminary USGS geophysical data obtained during summer 2008 using electrical resistivity methods indicate a near-surface resistive (consolidated) layer, possibly bedrock or till, along the northern and southern banks of the new channel in the area of the sand pit (figs. 5A-B, 14A-B). The nearsurface resistive layer (figs. 14A-B) on the north bank of the new channel in the sand pit is at an elevation higher than the river, extending to an elevation 3 to $6 \mathrm{ft}(0.9$ to $1.8 \mathrm{~m})$ below the right-bank terrace of the sand pit (approximately $8 \mathrm{ft}(2.4 \mathrm{~m})$ above the river thalweg), as shown in geophysical transect line 4 (fig. 14B). At cross section CU, the channel elevation is $303.38 \mathrm{ft}$ (NGVD 29), whereas the elevation of the top of the near-surface resistive layer on the north bank in the sand pit is approximately $311 \mathrm{ft}$ (NGVD 29). The 2-year recurrence-interval flood, which is approximately the bankfull, or channel-forming, discharge, is at an elevation of

$310.8 \mathrm{ft}$ at cross section CU. If the near-surface resistive layer is bedrock, it may serve to constrain lateral migration of the new channel into the former sand pit during bankfull flow. That constraint may avert the greater spatial and temporal influx downstream of sediment that could occur if the river were to migrate laterally into the sand-pit area. The extent of, and the degree to which, the near-surface resistive layer will constrain lateral migration of the river during flows greater than bankfull events remains unclear because geophysical data are limited.

\section{Sediment Load and its Effect on Streambed and Flood Elevations}

Simulation results and field-collected sediment data indicate that, for the daily mean flows downstream of the avulsion channel during the study field-collection period, approximately 70 to 500 tons of sediment per day were moving downstream past the Short Falls Road Bridge, approximately 0.02 to 50 tons of sediment per day were moving past the Route 28 bridge, and approximately 1.0 to 200 tons per day were moving past the Route 3 bridge. An analysis of the HEC-RAS quasi-unsteady-state flow model (table 9, fig. 15) showed that, for WY 2009 (October 1, 2008 through September 30, 2009), the mean daily sediment discharge (for mean daily flows) for all cross sections in WY 2009 was 165 tons per day, with a standard deviation of 

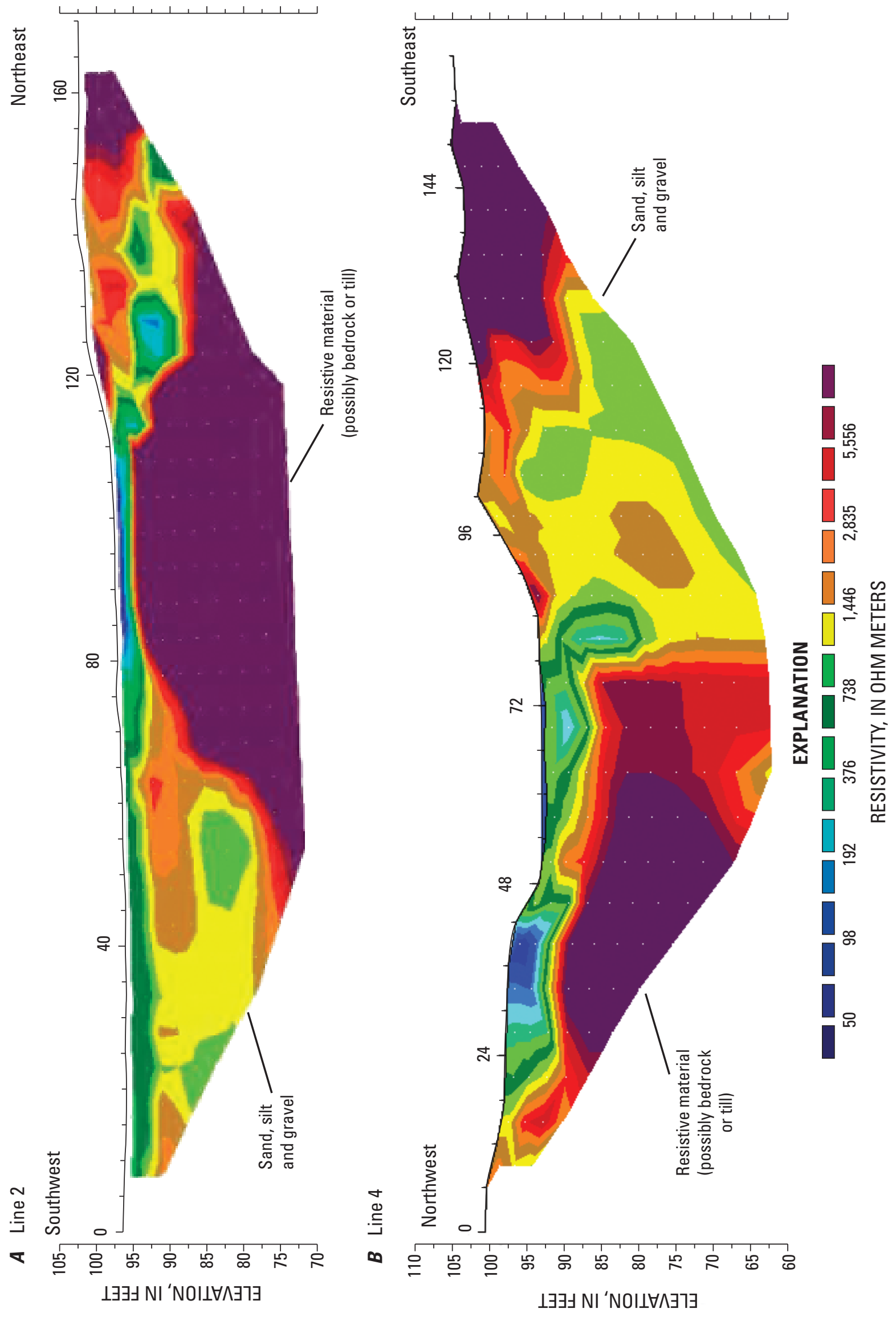

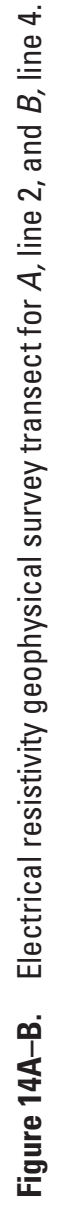


Table 9. Suncook River mean and median of the daily sediment discharges for water year 2009 using the Laursen (Copeland) function.

[ft, feet; WY, water year]

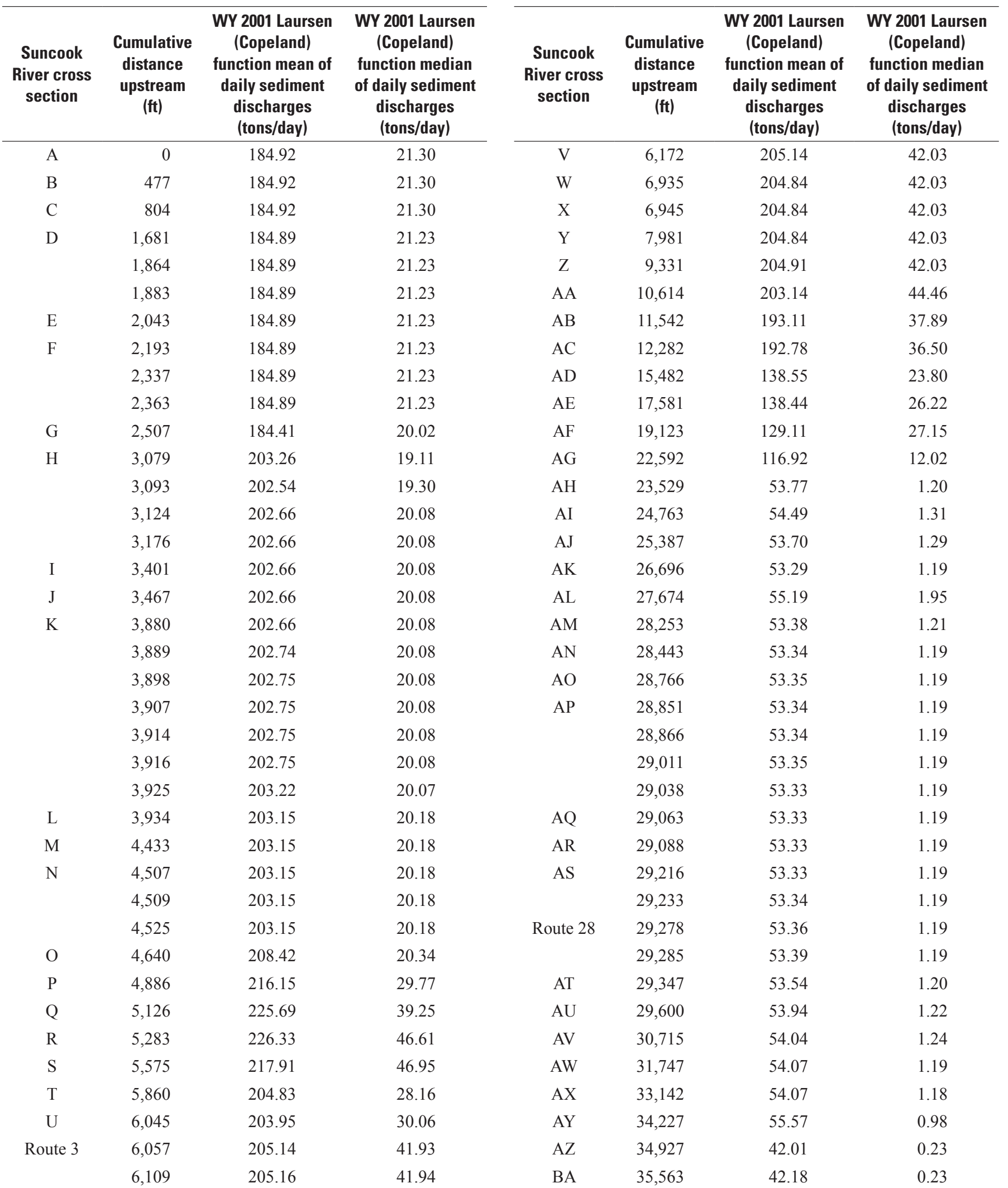


Table 9. Suncook River mean and median of daily sediment discharges for water year 2009 using the Laursen (Copeland) function. -Continued

[ft, feet; WY, water year]

\begin{tabular}{|c|c|c|c|c|c|c|c|}
\hline $\begin{array}{l}\text { Suncook } \\
\text { River cross } \\
\text { section }\end{array}$ & $\begin{array}{l}\text { Cumulative } \\
\text { distance } \\
\text { upstream } \\
\text { (ft) }\end{array}$ & $\begin{array}{l}\text { WY } 2001 \text { Laursen } \\
\text { (Copeland) } \\
\text { function mean of } \\
\text { daily sediment } \\
\text { discharges } \\
\text { (tons/day) }\end{array}$ & $\begin{array}{l}\text { WY } 2001 \text { Laursen } \\
\text { (Copeland) } \\
\text { function median } \\
\text { of daily sediment } \\
\text { discharges } \\
\text { (tons/day) }\end{array}$ & $\begin{array}{c}\text { Suncook } \\
\text { River cross } \\
\text { section }\end{array}$ & $\begin{array}{l}\text { Cumulative } \\
\text { distance } \\
\text { upstream } \\
\text { (ft) }\end{array}$ & $\begin{array}{l}\text { WY } 2001 \text { Laursen } \\
\text { (Copeland) } \\
\text { function mean of } \\
\text { daily sediment } \\
\text { discharges } \\
\text { (tons/day) }\end{array}$ & $\begin{array}{l}\text { WY } 2001 \text { Laursen } \\
\text { (Copeland) } \\
\text { function median } \\
\text { of daily sediment } \\
\text { discharges } \\
\text { (tons/day) }\end{array}$ \\
\hline BB & 36,078 & 38.98 & 0.23 & $\mathrm{CG}$ & 57,636 & 241.36 & 134.63 \\
\hline $\mathrm{BE}$ & 38,426 & 49.40 & 0.53 & CJ & 59,099 & 232.48 & 102.56 \\
\hline $\mathrm{BF}$ & 39,121 & 51.23 & 0.48 & $\mathrm{CK}$ & 59,429 & 232.61 & 102.15 \\
\hline BG & 39,861 & 73.49 & 1.11 & $\mathrm{CL}$ & 59,964 & 233.03 & 101.50 \\
\hline BH & 40,506 & 82.86 & 2.96 & $\mathrm{CM}$ & 60,520 & 233.84 & 100.05 \\
\hline $\mathrm{BL}$ & 43,741 & 83.80 & 3.65 & CQ & 63,035 & 223.87 & 117.27 \\
\hline $\mathrm{BM}$ & 44,821 & 88.31 & 5.74 & $\mathrm{CR}$ & 63,475 & 223.46 & 116.28 \\
\hline $\mathrm{BN}$ & 45,161 & 87.14 & 5.15 & $\mathrm{CS}$ & 63,795 & 217.96 & 116.25 \\
\hline $\mathrm{BO}$ & 45,724 & 83.73 & 4.14 & $\mathrm{CT}$ & 64,132 & 217.16 & 115.30 \\
\hline $\mathrm{BP}$ & 46,356 & 87.97 & 6.95 & $\mathrm{CU}$ & 64,400 & 210.75 & 102.00 \\
\hline BQ & 46,731 & 88.89 & 7.82 & $\mathrm{CV}$ & 64,632 & 212.03 & 102.08 \\
\hline $\mathrm{BR}$ & 47,375 & 94.16 & 11.35 & $\mathrm{CW}$ & 64,893 & 210.11 & 98.30 \\
\hline $\mathrm{BS}$ & 48,053 & 101.46 & 15.60 & $\mathrm{CX}$ & 65,150 & 210.37 & 97.93 \\
\hline BT & 48,853 & 110.62 & 24.49 & $\mathrm{CY}$ & 65,883 & 203.70 & 99.25 \\
\hline $\mathrm{BX}$ & 51,134 & 260.22 & 162.81 & $\mathrm{DE}$ & 66,929 & 202.96 & 90.65 \\
\hline \multirow{4}{*}{$\begin{array}{l}\text { Short Falls } \\
\text { Road }\end{array}$} & 51,175 & 260.28 & 163.21 & DF & 67,651 & 196.85 & 90.30 \\
\hline & & & & DG & 68,733 & 199.07 & 92.12 \\
\hline & 51,239 & 260.08 & 167.64 & $\mathrm{DH}$ & 69,552 & 195.58 & 91.19 \\
\hline & 51,254 & 260.25 & 167.30 & Route 4 & 69,665 & 195.58 & 91.19 \\
\hline BY & 51,305 & 260.00 & 164.99 & & 69,726 & 195.63 & 91.19 \\
\hline $\mathrm{BZ}$ & 51,975 & 258.48 & 163.25 & DI & 69,783 & 195.61 & 91.19 \\
\hline $\mathrm{CA}$ & 52,463 & 254.54 & 158.37 & & 69,998 & 195.59 & 91.12 \\
\hline $\mathrm{CB}$ & 53,600 & 250.28 & 146.94 & DJ & 70,008 & 195.43 & 91.41 \\
\hline $\mathrm{CC}$ & 54,415 & 243.88 & 122.96 & DK & 70,501 & 195.18 & 91.03 \\
\hline $\mathrm{CD}$ & 55,869 & 252.11 & 135.34 & DL & 70,813 & 194.44 & 93.16 \\
\hline $\mathrm{CE}$ & 56,345 & 247.99 & 144.21 & $\mathrm{DM}$ & 71,389 & 194.42 & 93.18 \\
\hline $\mathrm{CF}$ & 56,880 & 248.58 & 140.02 & $\mathrm{DN}$ & 71,617 & 192.30 & 90.23 \\
\hline
\end{tabular}




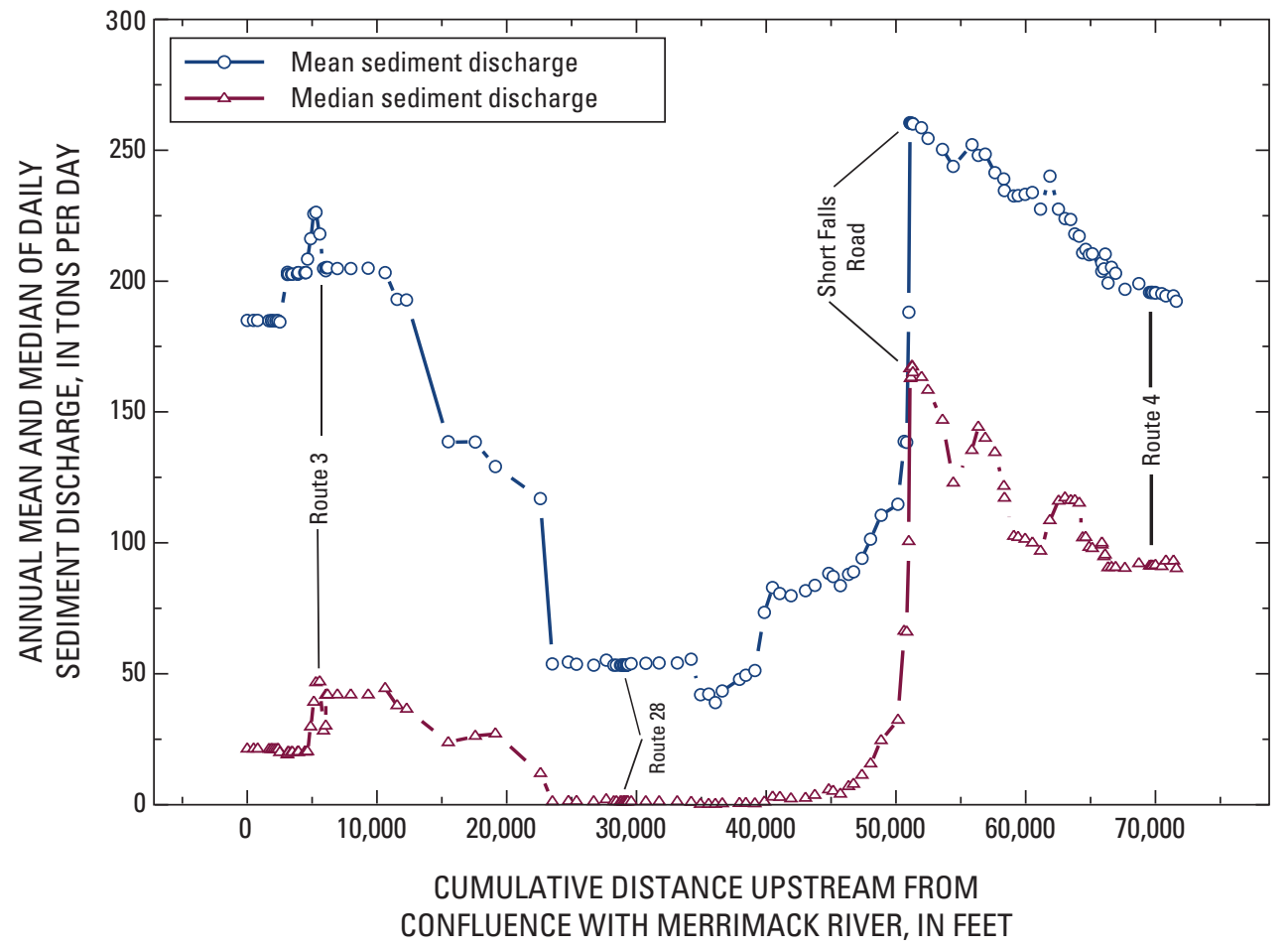

Figure 15. Suncook River mean and median of the daily sediment discharges for water year 2009 using the Laursen (Copeland) function.

70 tons per day, resulting in a coefficient of variation of 0.42 . For the Suncook River reach downstream of the Short Falls Road Bridge (table 9, fig. 15; between cross sections BW and $\mathrm{AD}$ ), the mean daily sediment discharge (for mean daily flows) in WY 2009 was 72 tons per day, with a standard deviation of 29 tons per day, resulting in a coefficient of variation of 0.40 (low variance). This reach is aggrading, retaining much of the sediment from the former sand pit upstream. The maximum daily mean sediment discharge for all daily mean flows in WY 2009 was 261 tons per day in the reach downstream of the Short Falls Road Bridge (table 9, fig. 4C; downstream of cross section BX). The minimum daily mean sediment discharge for WY 2009 was 39 tons per day and occurred at the reach upstream of the confluence of the Little Suncook River (figs. 2 and $4 \mathrm{C}$; downstream of cross section $\mathrm{BB}$ ).

In WY 2009, the maximum median of daily sediment discharges (for mean daily flows) for all cross sections was 168 tons per day, and occurred in the reach downstream of the Short Falls Road Bridge (figs. 2 and 4C; downstream of cross section BX). The minimum median of daily sediment discharges (for mean daily flows) for all cross sections for WY 2009 was 0.23 tons per day, and occurred at the reach upstream of the confluence of the Little Suncook River (figs. 2 and $4 \mathrm{C}$; downstream of cross section $\mathrm{BB}$ ). The average of the medians of daily sediment discharges (for mean daily flows) for all cross sections in WY 2009 was 53 tons per day, with a standard deviation of 50 tons per day, resulting in a coefficient of variation of 0.95 . Distributions of the coefficient of variation that are less than 1 are considered to be low variance. For the Suncook River reach downstream of the Short Falls Road Bridge (figs. 2 and $4 \mathrm{~A}-\mathrm{C}$; between cross sections BW and $\mathrm{AD}$ ), the average of the medians of daily sediment discharges (for mean daily flows) in WY 2009 was 7 tons per day, with a standard deviation of 14 tons per day, resulting in a coefficient of variation of 1.94 (high variance).

The sediment model using the Laursen (Copeland) transport function was used to determine sediment transport in WY 2010. Using daily mean flow and water temperature data from WY 2009, the quasi-unsteady-state sediment-transport model was run for a simulated water year ending September 30,2010 . The overall trend in the simulation is that sediment is being deposited (aggrading) downstream of the avulsionin particular, in the channel reach between the Short Falls Road Bridge and the Buck Street Dams - and sediment is being eroded from (degrading) the channel reach above the avulsion. 
The change in streambed thalweg for all of the crosssection locations from its elevation in May 2008 to its simulated elevation at the end of WY 2010 was a mean degradation of $0.46 \mathrm{ft}$ (median degradation of $0.57 \mathrm{ft}$ ). There was greater mean degradation (channel erosion) above the avulsion as compared to that below the avulsion for the model simulation period. The results show that for all of the crosssection locations, the overall degradation conditions resulted in the greatest impact for the higher annual exceedence probability (lower recurrence interval) floods with a decreased mean flood elevation for the 50-percent annual exceedence probability (2-year recurrence interval) of $0.39 \mathrm{ft}$ (median decrease of $0.01 \mathrm{ft}$ ).

The change in the streambed thalweg for the crosssection locations between the Short Falls Road Bridge and the Buck Street Dams for the simulation period from May 2008 to the end of WY 2010 was a mean increase of $0.88 \mathrm{ft}$ (median aggradation of $0.17 \mathrm{ft}$ ). The results show that this channel reach is continuing to fill with sediment with the greatest effect of the sediment deposition on water-surface elevation for the higher annual exceedence probability (lower recurrence interval) floods. The mean changes to the water-surface elevations for the cross sections between the Short Falls Road Bridge and the Buck Street Dams were an increase of $0.20 \mathrm{ft}$ (median of $0.14 \mathrm{ft}$ ) for the 50-percent annual exceedence probability (2-year recurrence interval) flood, $0.17 \mathrm{ft}$ (median of $0.16 \mathrm{ft}$ ) for the 10-percent annual exceedence probability (10-year recurrence interval) flood, $0.12 \mathrm{ft}$ (median of $0.13 \mathrm{ft}$ ) for the 2-percent annual exceedence probability (50-year recurrence interval) flood, $0.04 \mathrm{ft}$ (median of $0.05 \mathrm{ft}$ ) for the 1-percent annual exceedence probability (100-year recurrence interval) flood, and $0.06 \mathrm{ft}$ (median of $0.06 \mathrm{ft}$ ) for the 0.2 -percent annual exceedence probability (500-year recurrence interval) flood. The simulation results show that the increased aggradation in the reach between the Short Falls Road Bridge and the Buck Street Dams will yield an increase in observed flood elevations for the more frequently occurring lower recurrence interval floods.

The mean change to the water-surface elevations at all the cross sections was a lowering by $0.39 \mathrm{ft}$ (median of $0.01 \mathrm{ft}$ ) for the 50-percent annual exceedence probability (2-year recurrence interval) flood, $0.28 \mathrm{ft}$ (median of $0.03 \mathrm{ft}$ ) for the 10-percent annual exceedence probability (10-year recurrence interval) flood, $0.19 \mathrm{ft}$ (median of $0.06 \mathrm{ft}$ ) for the 2-percent annual exceedence probability (50-year recurrence interval) flood, $0.18 \mathrm{ft}$ (median of $0.14 \mathrm{ft}$ ) for the 1-percent annual exceedence probability (100-year recurrence interval) flood, and $0.16 \mathrm{ft}$ (median of $0.14 \mathrm{ft}$ ) for the 0.2 -percent annual exceedence probability (500-year recurrence interval) flood. The overall decrease in the selected annual exceedence flood elevations at the model cross-section locations reflects the mean degradation of $0.46 \mathrm{ft}$ for these cross sections. As indicated previously for the reach between the Short Falls Road Bridge and the Buck Street Dams, subreaches can have an overall increase in the selected annual exceedence probability floods.

\section{Summary}

During May 13-16, 2006, rainfall in excess of 8.8 inches flooded central and southern New Hampshire. A breach in the bank of the Suncook River in Epsom, N.H., on May 15, 2006, caused the river to follow a new path. The Suncook River drains several lakes south of Lake Winnepsaukee, and, it flows approximately 30 miles to the Merrimack River at a location between Concord and Manchester, N.H. Before the May flood, the Suncook River flowed southward around Bear Island in two stream reaches that joined west of Round Pond. After May 16, 2006, there was no flow in the western reach or in the northeastern reach of the Suncook River around Bear Island. Instead, the Suncook River created a path through a gravel pit, resulting in a new channel upstream of Bear Island and two new dams at the north end of Bear Island, with the new channel rejoining the old channel to the east of Bear Island. During April 16-18, 2007, more than 7 inches of precipitation resulted in another flood event. Both floods transported large quantities of gravel, sand, silt, and clay downstream. In order to assess and predict the effects of the sedimentand the subsequent flooding on the river and flood plain, a study by the U.S. Geological Survey characterizing sediment transport in the Suncook River was undertaken in cooperation with the Federal Emergency Management Agency and the New Hampshire Department of Environmental Services.

For many rivers, the relation between suspended sediment and explanatory variables such as discharge is not constant over time, making accurate forecasts of changes in streambeds difficult. Although several factors affect sediment discharge, transport and discharge of sediment are closely tied to flow. Knowledge of flow data is critical in predicting sediment transport and the resultant effect of streambed and total sediment load on recurrence-interval floods. An understanding of sediment-transport characteristics is important for applications that include flow-regime change, channel-restoration efforts, and predictions of the effects of landuse (Wilcock, 2001). In order to establish river equilibrium for river-corridor protection and restoration, knowledge of the relation between flow and sediment transport and the of the ability of the existing channel to transport sediment is critical. The measurement of sediment load and particle size moving through a reach at various flows for development of sediment-rating curves is an important tool for river-corridor protection and restoration design. Once the conditions required for sediment transport are understood, a determination of the channel dimensions, pattern, and profile required for sufficient transport of the expected sediment supply can be made (Vermont Agency of Natural Resources, 2009).

As a result of the avulsion, the new channel through the gravel pit is 1.0 mile (mi) long, whereas the abandoned channel is $2.0 \mathrm{mi}$ long. It was estimated that 150,000 cubic yards of sediment were introduced into the Suncook River, with sheets of silt and sand up to 5 feet (ft) thick, deposited downstream of the avulsion channel. Downcutting of the stream continues in the avulsion area and upstream because 
of the increased gradient and the convergence of flow, both of which increase the rate of erosion of the bank in the avulsion area and upstream.

A one-dimensional sedimentation model (HEC-RAS, version 4.0.0) of the Suncook River was developed for the reach from its confluence with the Merrimack River in Allenstown to the upstream limit of Epsom (15.9 mi) to study the effect of the streambank avulsion on sediment transport. The study was undertaken and the sedimentation model was created to aid State and local authorities in predicting sediment levels, riverbed stability, and sediment movement under various flow scenarios, and to assist future restoration efforts by furthering the understanding of the effect of sediment transport on the environment.

Developing and verifying the model required obtaining data on the profile of and cross sections in the channel and on the overbanks, on bed sediments, on inflowing concentrations of sediment, and on daily discharges. Verification of sedimentation patterns consisted of comparing the observed changes in cross sections of the channel with computed changes in these cross sections for a 400-day period during 2008 and 2009.

Field data were collected at bridges, dams, and 148 channel cross sections. Cross sections were surveyed with a total station using closed level-loop surveying techniques from either a known reference datum or from a reference datum established using a Global Positioning System (GPS) with a horizontal accuracy of $3 \mathrm{~mm}(0.01 \mathrm{ft})$ and a vertical accuracy of $10 \mathrm{~mm}(0.03 \mathrm{ft})$ in static mode. Additional cross-section and profile data were collected using a GPS in conjunction with an Acoustic Doppler Current Profiler.

The sediment model using the Laursen (Copeland) transport function was used to determine sediment transport and streambed elevations for the end of water year (WY) 2010. Using channel geometry and daily mean flow and watertemperature data from WY 2009, the quasi-unsteady-state sediment-transport model was run for WY 2010. The resultant cross sections were imported into a steady-state flow model, which was then run to determine the impact of the altered channel bed on flood elevations for the 50-, 10-, 2-, 1-, and 0.2 -percent annual exceedence probability floods. The predicted change in streambed thalweg at all of the model crosssection locations between May 2008 and the end of WY 2010 was a mean degradation of $0.46 \mathrm{ft}$ (median degradation of $0.57 \mathrm{ft}$ ). The model simulation shows that for all cross-section locations, overall degradation resulted in the greatest impact for the higher annual exceedence probability (lower recurrence interval) floods with a decreased mean flood elevation for the 50-percent annual exceedence probability (2-year recurrence interval) flood of $0.39 \mathrm{ft}$ (median decrease of $0.01 \mathrm{ft}$ ).

The change in the streambed thalweg for the crosssection locations between the Short Falls Road Bridge and the Buck Street Dams for the simulation period from May 2008 to the end of WY 2010 was a mean aggradation (deposition of sediment) of $0.88 \mathrm{ft}$ (median aggradation of $0.17 \mathrm{ft}$ ). The results show that this channel reach is continuing to fill with sediment, with the greatest effect of the sediment deposition on water-surface elevations for the higher annual exceedence probability (lower recurrence interval) floods. For the 50-percent annual exceedence probability (2-year recurrence interval) flood, the simulated mean aggradation of $0.88 \mathrm{ft}$ (median aggradation of $0.17 \mathrm{ft}$ ) resulted in an increased mean flood elevation of $0.20 \mathrm{ft}$ (median increase of $0.14 \mathrm{ft}$ ).

The mean change to the water-surface elevations at all the cross sections was a lowering by $0.39 \mathrm{ft}$ (median of $0.01 \mathrm{ft}$ ) for the 50-percent annual exceedence probability (2-year recurrence interval) flood, $0.28 \mathrm{ft}$ (median of $0.03 \mathrm{ft}$ ) for the 10-percent annual exceedence probability (10-year recurrence interval) flood, $0.19 \mathrm{ft}$ (median of $0.06 \mathrm{ft}$ ) for the 2-percent annual exceedence probability (50-year recurrence interval) flood, $0.18 \mathrm{ft}$ (median of $0.14 \mathrm{ft}$ ) for the 1-percent annual exceedence probability (100-year recurrence interval) flood and $0.16 \mathrm{ft}$ (median of $0.14 \mathrm{ft}$ ) for the 0.2 -percent annual exceedence probability (500-year recurrence interval) flood.

Simulation results and field-collected sediment data indicate that, for the average daily mean flow during the study period and downstream of the avulsion channel, approximately 70 to 500 tons of sediment per day were moving downstream past the Short Falls Road Bridge; that approximately 0.02 to 50 tons of sediment per day were moving past the Route 28 bridge; and that approximately 1.0 to 200 tons per day were moving past the Route 3 bridge. The sediment-transport rate for the average daily mean flow at the Route 28 bridge was lower than the sediment-transport rate at the downstream Route 3 bridge and at the upstream Short Falls Road Bridge during the study period; this difference reflects the large quantity of sediment that is still moving downstream from the sand pit and the reach above Short Falls and that is settling out in the river downstream of Short Falls and upstream of Route 28. A much lower rate of sediment transport, likely a result of the large quantity of sediment that was deposited during the 2006 and 2007 peak-flow events, is occurring at Route 28 as compared to Route 3 . The sediment remains in the channel and on the flood plain in this reach and is still moving downstream in the reach downstream of Route 28 .

Data from the model and from measured cross sections and field-collected sediment verify that much of the sediment is being deposited (aggrading) downstream of the avulsion - in particular, in the channel reach between the Short Falls Road Bridge and the Buck Street Dams - and sediment is being eroded from (degrading) the channel reach above the avulsion and in Leighton Brook.

The shear stress analysis results for the Route 28 bridge are in contrast to those of the next upstream bridge at Short Falls Road, where sediment smaller than or equal in size to a medium sand was in motion and suspension for 100 percent of the study simulation days. The analysis for the Route 28 bridge shows that for only 25 to 32 percent of the simulation days, sediment smaller than or equal in size to a medium sand was in motion; in addition, the analysis indicates that the reach between Short Falls Road Bridge and the downstream Route 28 bridge is retaining much of its coarser sediment load given the streambed shear stress and the median grain size $\left(d_{50}\right)$ of a 
very fine gravel for all sediment-sampling locations below the avulsion and of a coarse sand at the Short Falls Road Bridge. Shear stress is a function of the energy gradient (or slope of the water surface) and hydraulic radius (approximated by the mean depth). An increase in either or both of these parameters will result in greater shear stress and an increased ability of the channel to move sediment.

Aerial photographs taken in 2007 and 11 months later in 2008 in the area of the new channel through the sand pit show that the new channel reach is continuing to transport and deposit sediment and that there has been some bank erosion, but that there is little channel migration in the area of the sand pit. Preliminary geophysical data indicate that a potential near-surface consolidated layer may constrain the new channel from laterally migrating into the sand pit area.

The driving force for sediment transport is the shear stress $\left(\tau_{0}\right)$ that flowing water exerts on the channel boundary. Sediment movement, or entrainment, in a stream is in part an effect of this boundary shear stress that flowing water creates by acting on sediment particles. The potential for entrainment is estimated from the relation between a flood-generated shear stress and the critical shear stress $\left(\tau_{c}\right)$, the shear stress at which sediment particles begin to move. Critical shear stress has been related to characteristics of sediment size. A shear stress analysis was undertaken to determine potential areas of erosion and deposition. The distribution of streambed shear stress for the 50- and 1-percent annual exceedence probability floods (2- and 100-year recurrence interval floods, respectively) and the critical streambed shear stress based on the $d_{50}$ particle size were determined in order to define the areas for which little to no sediment is predicted as moving (as defined by: $\tau_{0}$ less than $\tau_{\mathrm{c}}$ ), some sediment is predicted as moving (as defined by: $\tau_{0}$ greater than $\tau_{\mathrm{c}}$ and $\tau_{0}$ less than $2 \tau_{\mathrm{c}}$ ), and much sediment is predicted as moving (as defined by: $\tau_{0}$ greater than $2 \tau_{\mathrm{c}}$ ) for either the 50 - or 1-percent annual exceedence probability (2- or 100-year recurrence-interval, respectively) floods. Based on the median grain size $\left(d_{50}\right)$ and shear stress analysis, the study found that, in general, for floods greater than the 50-percent annual exceedence probability (2-year recurrence interval) flood, the shear stress in the river is greater than the critical shear stress in much of the river study reach. The expected result is that streambed sediment movement and erosion will happen even at high exceedence probability events in the streambed, pending stream equilibrium through stream-stabilization measures or over time as described by Lane's stream-balance relation. The potential for aggradation in the Suncook River is greatest in the reach downstream of the avulsion and, specifically, in the reaches downstream of the former sand pit from adjacent to Round Pond to downstream of the flood chute at the large meander bends (cross sections CA to $\mathrm{CM}$ ) and from downstream of the Short Falls Road Bridge to approximately $3,800 \mathrm{ft}$ upstream of the Route 28 bridge.

\section{References Cited}

Ackers, P., and White, W.R., 1973, Sediment transport-New approach and analysis: Journal of the Hydraulics Division, American Society of Civil Engineers, v. 99, no. HY11, p. 2040-2060.

American Society of Civil Engineers (ASCE) (2006), Sedimentation engineering, in Vanoni, V.A., ed., ASCE Manuals and Reports on Engineering Practice: Reston, Va., no. $54,418 \mathrm{p}$.

American Society of Civil Engineers (ASCE) (2008), Sedimentation engineering-Processes, measurements, modeling and practice, in Garcia, M.H., ed., ASCE Manuals and Reports on Engineering Practice no. 110: Reston, Va., $1,132 \mathrm{p}$.

American Society for Testing and Materials, 2004, Standard guide for sampling fluvial sediment in motion: American Society for Testing and Materials, ASTM D 4411-0, Section 3.1.4.

Arcement, G.J., and Schneider, V.R., 1989, Guide for selecting Manning's roughness coefficients for natural channels and floodplains: U.S. Geological Survey Water-Supply Paper 233, $69 \mathrm{p}$.

Barnes, H.H., Jr., 1967, Roughness characteristics of natural channels: U.S. Geological Survey Water-Supply Paper $1849,213 \mathrm{p}$.

Berenbrock, Charles, and Bennett, J.P., 2005, Simulation of flow and sediment transport in the white sturgeon spawning habitat of the Kootenai River near Bonners Ferry, Idaho: U.S. Geological Survey Scientific Investigations Report 2005-5173, $81 \mathrm{p}$.

Brunner, G., and Gibson, S., 2005, Sediment transport modeling in HEC-RAS (Hydrologic Engineering Centers River Analysis System), in World Water and Environmental Resources Congress, May 15-19, 2005, ASCE Conference Proceedings 173: Anchorage, Alaska, Environmental and Water Resources Institute of the American Society of Civil Engineers, p. 442.

Colby, B.R., 1964, Discharge of sands and mean-velocity relationships in sand-bed streams: U.S. Geological Survey Professional Paper 462-A, 47 p.

Colby, B.R., and Scott, C.H., 1965, Effects of water temperature on the discharge of bed material: U.S. Geological Survey Professional Paper 462-G, p. G1-G25.

Copeland, R.D., and Thomas, W.A., 1989, Corte Madera Creek sedimentation study: Vicksburg, Miss., U.S. Army Corps of Engineers, Waterways Experiment Station, Technical Report HL 89-6. 
Davis, B.E., 2005, A guide to the proper selection and use of federally approved sediment and water-quality samplers: U.S. Geological Survey Open-File Report 2005-1087, 26 p.

Eastern Topographics, 2007, Photogrammetric ground control report for the Town of Epsom, N.H., Suncook River area, Epsom, N.H.: Eastern Topographics, R10B/10343\{3\}-1, imagery acquired on May 12, 2007, September 13, 2007, NGVD 29, 1-foot contour-interval, scale 1:12,000.

Eastern Topographics, 2008, Photogrammetric ground control report for the Towns of Epsom and Allenstown, N.H., Suncook River area, Epsom and Allenstown, N.H.: Eastern Topographics, R10A/10573, imagery acquired on April 18, 2008 and May 27, 2008, NGVD 29, 4-foot contour-interval, scale $1: 12,000$

Edwards, T.K., and Glysson, G.D., 1999, Field methods for measurement of fluvial sediment: U.S. Geological Survey Techniques of Water-Resources Investigations, book 3, Applications of Hydraulics, chap. C2, 89 p.

Engelund, F., and Hansen, E., 1967, A monograph on sediment transport in alluvial streams: Teknisk Vorlang, Copenhagen, $62 \mathrm{p}$.

Federal Interagency Sedimentation Project, 1941, Analytical study of methods of sampling suspended sediment: Federal Interagency Sedimentation Project, Report no. 3, p. 14.

Federal Interagency Stream Restoration Working Group (1998, revised 2001, Stream corridor restorationPrinciples, processes and practices: GPO Item No. 0120-A; SupDocs no. A 57.6/2:EN3/PT.653, ISBN-0-934213-59-3.

Flynn, R.H., 2008, Flood of April 2007 in New Hampshire: U.S. Geological Survey Scientific Investigations Report 2008-5120, 48 p.

Flynn, R.H., 2010, Flood study of the Suncook River in Epsom, Pembroke, and Allenstown, New Hampshire, 2009: U.S. Geological Survey Scientific Investigations Report 2010-5127, 64 p.

Gibson, S., Brunner, G., Piper, S., and Jensen, M., 1996, Sediment transport computations with HEC-RAS, in Eighth Federal Interagency Sedimentation Conference, Proceedings: Reno, Nev., April 2-6, 2006, 8 p.

Glysson, G.D., 1987, Sediment transport curves: U.S. Geological Survey Open-File Report 87-218, 47 p.

Interagency Committee on Water Resources, 1957, Some fundamentals of particle size analysis: St. Anthony Falls Hydraulic Laboratory, Minneapolis, Minn.

Lane, E.W., 1955, The importance of fluvial morphology in hydraulic engineering, in Proceedings: American Society of Civil Engineers, no. 745, July 1955.
Laursen, E.M., 1958, Total sediment load of streams: American Society of Civil Engineers, Journal of Hydraulics Division, v. 84, no. HY 1, p. 1530:1-1530:36.

Leica Geosystems, 2008, Leica GPS1200, GPS1200 surveying systems, accessed November 9, 2008, at http://www.leicageosystems.com/en/Leica-GPS1200_4521.htm.

Leopold, L.B., 1994, A view of the river: Harvard University Press, Cambridge, Mass., 298 p.

Leopold, L.B., and Maddock, T., Jr., 1953, The hydraulic geometry of stream channels and some physiographic implications: U.S. Geological Survey Professional Paper $252,57 \mathrm{p}$.

Lisle, T.E., Iseya, F., and Ikeda, H., 1993, Response of a channel with alternate bars to a decrease in supply of mixed-size bedload-A flume experiment: Water Resources Research, v. 29, no. 11, p. 3623-3629.

Lyons, J.B., Bothner, W.A., Moench, R.H., and Thompson, J.B., Jr., eds., 1986, Interim geologic map of New Hampshire: Concord, N.H., New Hampshire Department of Resources and Economic Development, Open-File Report 86-1, map, scale 1:250,000.

Meyer-Peter, B., and Muller, T., 1948, Formulas for bedload transport, in Report on Second Meeting of International Association for Hydraulics Research: Stockholm, Sweden, International Association for Hydraulics Research, p. 39-64.

Muller, D.S., and Wagner, C.R., 2009, Measuring discharge with acoustic doppler current profilers from a moving boat: U.S. Geological Survey Techniques and Methods 3A-22, 72 p. (Also available online at http://pubs.water.usgs.gov/ tm3a22.)

National Climate Data Center, 2008, Local climatological data annual summary with comparative data Concord, New Hampshire (National Climate Data Center, accessed April 22, 2009, at http://www1.ncdc.noaa.gov/pub/orders/ FF3E95A7-6803-492A-7054-C33BBF06B197.PDF.

National Water Information System (NWIS), USGS Water Data for New Hampshire, accessed February 10, 2011, at http://waterdata.usgs.gov/nh/nwis/.

New Hampshire Department of Transportation, 2006, 2005 1-foot color aerial imagery-Southeast New Hampshire: New Hampshire Department of Transportation, imagery acquired at an elevation of approximately 9,800 feet above mean sea level on May 11, 2005.

New Hampshire Employment Security, Economic and Labor Market Information Bureau, 2009a, Community profiles (Allenstown, N.H.), accessed October 12, 2010, at http:// www.nh.gov/nhes/elmi/htmlprofiles/pdfs/allenstown.pdf. 
New Hampshire Employment Security, Economic and Labor Market Information Bureau, 2009b, Community profiles (Chichester, N.H.), accessed October 12, 2010, at http:// www.nh.gov/nhes/elmi/htmlprofiles/pdfs/chichester.pdf

New Hampshire Employment Security, Economic and Labor Market Information Bureau, 2009c, Community profiles (Epsom, N.H.), accessed October 12, 2010, at http://www. nh.gov/nhes/elmi/htmlprofiles/pdfs/epsom.pdf.

New Hampshire Employment Security, Economic and Labor Market Information Bureau, 2009d, Community profiles (Pembroke, N.H.), accessed October 12, 2010, at http:// www.nh.gov/nhes/elmi/htmlprofiles/pdfs/pembroke.pdf.

Olson, S.A., 2007, Flood of May 2006 in New Hampshire: U.S. Geological Survey Open-File Report 2007-1122, 32 p., accessed August 28, 2010, at http://pubs.water.usgs. gov/ofr2007-1122.

Perignon, M., 2008, Sediment wave-induced channel evolution following the 2006 avulsion of the Suncook River in Epsom, New Hampshire: Cambridge, Mass., Massachusetts Institute of Technology, Master of Science thesis, $95 \mathrm{p}$.

Porterfield, George, 1972, Computation of fluvial-sediment discharge: U.S. Geological Survey Techniques of WaterResources Investigations, book 3, chap. C3, 66 p.

Reinfelds, I., Cohen, T., Batten, P., and Brierley, G., 2003, Assessment of downstream trends in channel gradient, total and specific stream power-a GIS approach: Geomorphology, v. 60, issues 3-4, p. 403-416.

Rosgen, D.L., 2001, A stream channel stability assessment methodology, in Proceedings of the Seventh Federal Interagency Sedimentation Conference, March 25 to 29, 2001, Reno, Nevada. The conference was sponsored by the Subcommittee on Sedimentation (includes staff from ARS, USACE, BLM, USBR, USEPA, FHWA, USFS, USGS, NPS, NRCS, OSMRE, and TVA).

Rouse, H., 1937, Modern conceptions of the mechanics of fluid turbulence: Transactions of the American Society of Civil Engineers, v. 102, p. 463-541.

Salas, J.D., 1993, Analysis and modeling of hydrologic time series, in Maidment, D.A., ed., Handbook of Hydrology: McGraw-Hill, N.Y., chap. 19, 72 p.

Shields, A.F., 1936, Application of similarity principles and turbulence research to bedload movement: Translated from Anwendung der Ächnlichkeits Geschiebebewegung, in Mirte Preuss, VersAnsr, Wasserh, Schifih, W.D. Ott and J.C. von Vcheten., eds., Calif.: Institute Technol. Hjdrodyn, Laboratory no. 167, 36 p.
Stekl, P.J., and Flanagan, S.M., 1997, Geohydrology and water quality of stratified-drift aquifers in the upper Merrimack River Basin, south-central New Hampshire: U.S. Geological Survey Water-Resources Investigations Report 95-4123, 137 p., 8 pls.

Thomas, W.A., 1977, Sediment transport-International Hydrological Decade, hydrologic engineering methods for water resources development: Davis, Calif., Hydrologic Engineering Center, v. 12 (IHD-12), 225 p.

Toffaleti, F.B., 1968, A procedure for computation of total river sand discharge and detailed distribution, bed to surface: U.S. Army Corps of Engineers, Committee on Channel Stabilization, November 1968, Technical Report No. 5.

U.S. Army Corps of Engineers, 1993, HEC-6 scour and deposition in rivers and reservoirs-User's manual: Davis, Calif., Hydrologic Engineering Center.

U.S. Army Corps of Engineers, 2008a, Hydrologic Engineering Center-River Analysis System (HEC-RAS), v. 4.0.0, March 2008: Davis, Calif., Hydrologic Engineering Center.

U.S. Army Corps of Engineers, 2008b, Hydrologic Engineering Center-River Analysis System (HEC-RAS), HEC-RAS features: Davis, Calif., Hydrologic Engineering Center, accessed March 29, 2009, at http://www.hec.usace. army.mil/software/hec-ras/hecras-features.html.

U.S. Army Corps of Engineers, 2008c, Hydrologic Engineering Center-River Analysis System (HEC-RAS) CPD-69, Hydraulic reference manual, v. 4.0.0, March 2008: Davis, Calif., Hydrologic Engineering Center, 411 p.

U.S. Department of Housing and Urban Development Federal Insurance Administration, 1978a, Flood-insurance study, Town of Allenstown, Merrimack County, New Hampshire: Washington, D.C., $16 \mathrm{p}$.

U.S. Department of Housing and Urban Development Federal Insurance Administration, 1978b, Flood-insurance study, Town of Epsom, Merrimack County, New Hampshire: Washington, D.C., 19 p.

U.S. Department of Housing and Urban Development Federal Insurance Administration, 1978c, Flood-insurance study, Town of Pembroke, Merrimack County, New Hampshire: Washington, D.C., $17 \mathrm{p}$.

U.S. Environmental Protection Agency, 2008a, Watershed assessment of river stability and sediment supply (WARSSS), accessed November 5, 2009, at http://www.epa. gov/warsss/sedsource/bankfull.htm. 
U.S. Environmental Protection Agency, 2008b, Watershed assessment of river stability and sediment supply (WARSSS), accessed November 5, 2009, at http://www.epa. gov/warsss/sedsource/bedload.htm.

U.S. Environmental Protection Agency, 2008c, Watershed assessment of river stability and sediment supply (WARSSS), accessed November 5, 2009, at http://www.epa. gov/warsss/sedsource/rivstab.htm.

U.S. Environmental Protection Agency, 2008d, Watershed assessment of river stability and sediment supply (WARSSS), accessed November 5, 2009, at http://www.epa. gov/warsss/sedsource/degrad.htm.

U.S. Environmental Protection Agency, 2008e, Watershed assessment of river stability and sediment supply (WARSSS), accessed November 5, 2009, at http://www.epa. gov/warsss/sedsource/aggrad.htm.

Vanasse Hangen Brustlin, Inc., 2008, Suncook River avulsion, geomorphology-based alternatives analysis: Bedford, N.H., Parish Geomorphic and Kleinschmidt Associates, prepared for the Town of Epsom, N.H., and New Hampshire Department of Environmental Services, $82 \mathrm{p}$.

Vermont Agency of Natural Resources, 2009, Stream geomorphic assessment handbooks: Montpelier, Vt., Vermont Stream Geomorphic Assessment, appendix O, 6 p.

Wilcock, P.R., 2001, Toward a practical method for estimating sediment-transport rates in gravel bed rivers: Earth Surface Processes and Landforms, v. 26, p. 1395-1408.

Wilcock, P.R., and McArdell, B.W., 1993, Surface-based fractional transport rates-Mobilization thresholds and partial transport of a sand-gravel sediment: Water Resources Research, v. 29, no. 4, p. 1297-1312.

Wolman, M.G., 1954, Method of sampling coarse river-bed material: Transactions of the American Geophysical Union, v. 35 , no. 6 , p. $951-956$.

Wolman, M.G., and Leopold, L.B., 1957, River flood plainsSome observations on their formation: U.S. Geological Survey Professional Paper 282-C, p. 87-109.

Wolman, M.G., and Miller, J.P., 1960, Magnitude and frequency of forces in geomorphic processes: Journal of Geology, v. 68, p. 54-74.

Yang, C.T., 1973, Incipient motion and sediment transport: Journal of the Hydraulics Division, American Society of Civil Engineers, v. 99, no. HY10, October 1973, p. $1679-1704$. 
Table 7. Comparison of Hydrologic Engineering Center-River Analysis System (HEC-RAS)-predicted flood elevations for 2008 and the end of water year 2010 for the 50-, 10-, 2-, 1-, and 0.2-percent annual exceedence probability floods and streambed elevations at each cross section.

[Location of cross sections A-DW are shown in figure 4. WY, water year; \%, percent; $\mathrm{ft}^{3} / \mathrm{s}$, cubic feet per second; ft, feet; NGVD 29, National Geodetic Vertical Datum of 1929]

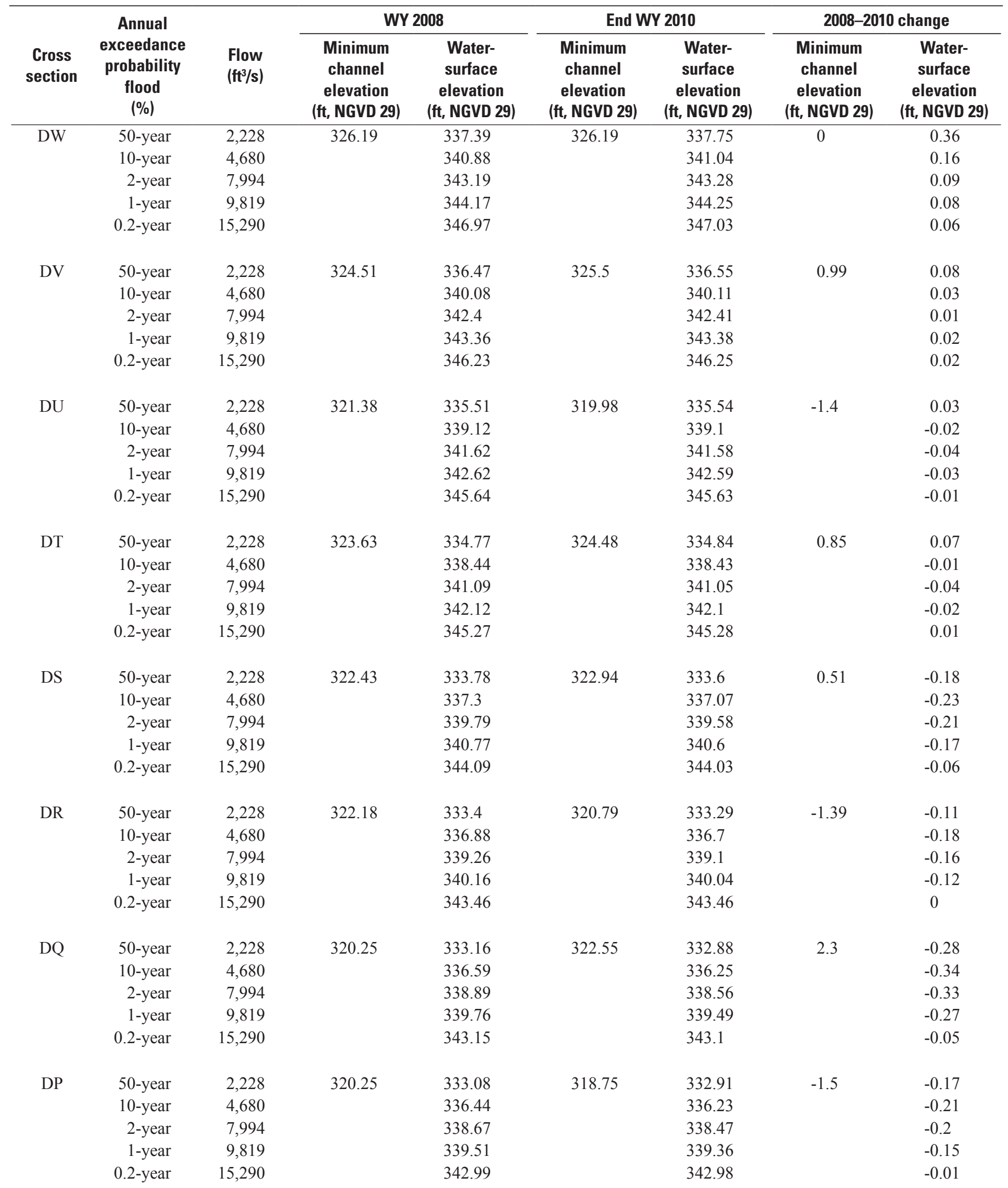


Table 7. Comparison of Hydrologic Engineering Center-River Analysis System (HEC-RAS)-predicted flood elevations for 2008 and the end of water year 2010 for the 50-, 10-, 2-, 1-, and 0.2-percent annual exceedence probability floods and streambed elevations at each cross section.-Continued

[Location of cross sections A-DW are shown in figure 4. WY, water year; \%, percent; $\mathrm{ft}^{\mathrm{t}} / \mathrm{s}$, cubic feet per second; ft, feet; NGVD 29, National Geodetic Vertical Datum of 1929]

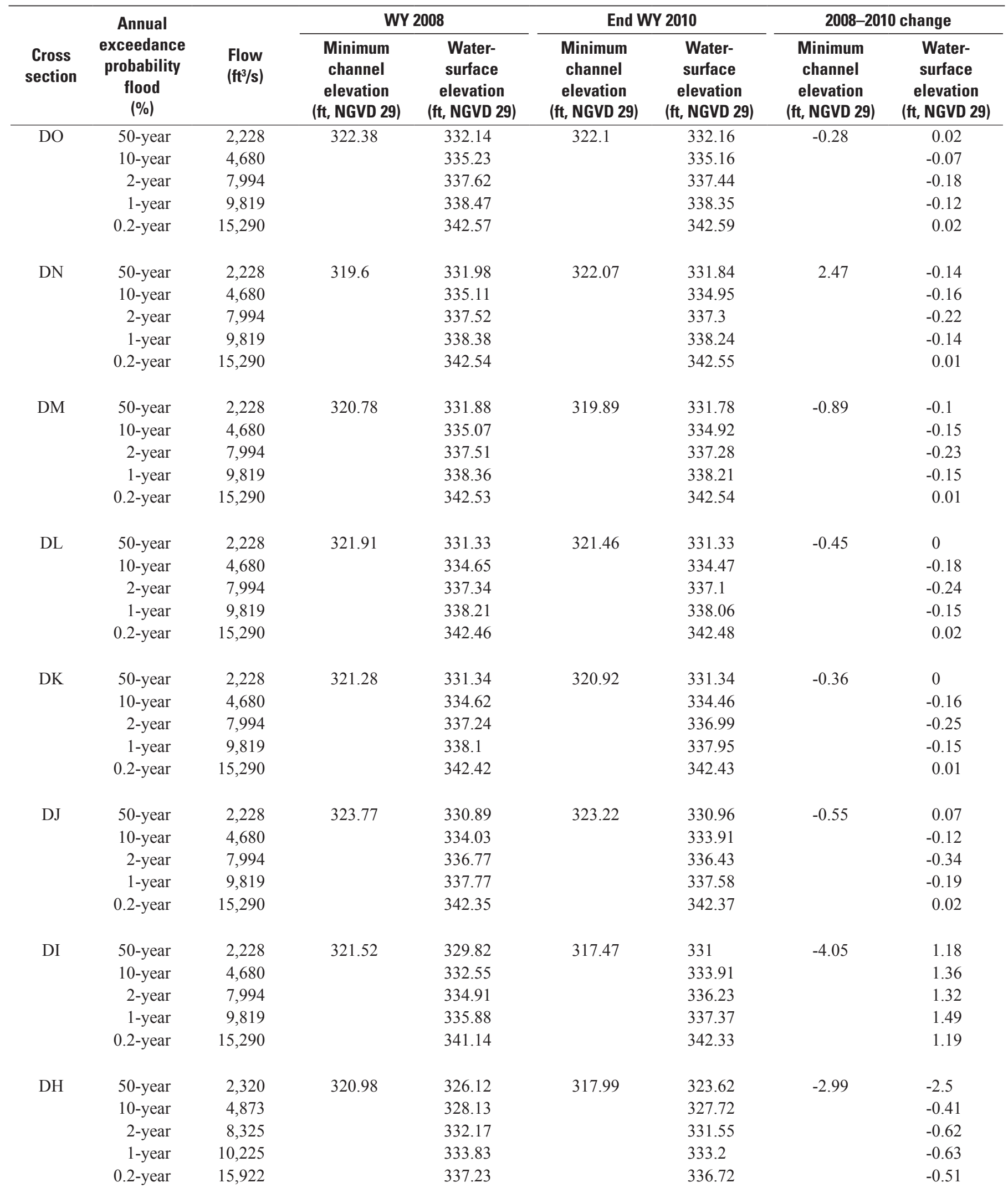


Table 7. Comparison of Hydrologic Engineering Center-River Analysis System (HEC-RAS)-predicted flood elevations for 2008 and the end of water year 2010 for the 50-, 10-, 2-, 1-, and 0.2-percent annual exceedence probability floods and streambed elevations at each cross section.-Continued

[Location of cross sections A-DW are shown in figure 4. WY, water year; \%, percent; $\mathrm{ft}^{3} / \mathrm{s}$, cubic feet per second; ft, feet; NGVD 29, National Geodetic Vertical Datum of 1929]

\begin{tabular}{|c|c|c|c|c|c|c|c|c|}
\hline \multirow[b]{2}{*}{$\begin{array}{c}\text { Cross } \\
\text { section }\end{array}$} & \multirow{2}{*}{$\begin{array}{l}\text { Annual } \\
\text { exceedance } \\
\text { probability } \\
\text { flood } \\
(\%)\end{array}$} & \multirow[b]{2}{*}{$\begin{array}{l}\text { Flow } \\
\left(\mathrm{ft}^{3} / \mathrm{s}\right)\end{array}$} & \multicolumn{2}{|c|}{ WY 2008} & \multicolumn{2}{|c|}{ End WY 2010} & \multicolumn{2}{|c|}{ 2008-2010 change } \\
\hline & & & $\begin{array}{c}\text { Minimum } \\
\text { channel } \\
\text { elevation } \\
\text { (ft, NGVD 29) }\end{array}$ & $\begin{array}{c}\text { Water- } \\
\text { surface } \\
\text { elevation } \\
\text { (ft, NGVD 29) }\end{array}$ & $\begin{array}{l}\text { Minimum } \\
\text { channel } \\
\text { elevation } \\
\text { (ft, NGVD 29) }\end{array}$ & $\begin{array}{c}\text { Water- } \\
\text { surface } \\
\text { elevation } \\
\text { (ft, NGVD 29) }\end{array}$ & $\begin{array}{c}\text { Minimum } \\
\text { channel } \\
\text { elevation } \\
\text { (ft, NGVD 29) }\end{array}$ & $\begin{array}{c}\text { Water- } \\
\text { surface } \\
\text { elevation } \\
\text { (ft, NGVD 29) }\end{array}$ \\
\hline \multirow[t]{3}{*}{ DG } & 50-year & 2,320 & 302.68 & 324.42 & 302.26 & 323.43 & -0.42 & -0.99 \\
\hline & 10-year & 4,873 & & 327.83 & & 327.04 & & -0.79 \\
\hline & 0.2 -year & 15,922 & & 336.35 & & 335.72 & & -0.63 \\
\hline \multirow[t]{3}{*}{$\mathrm{DF}$} & 50-year & 2,854 & 313.22 & 323.8 & 313.74 & 322.52 & 0.52 & -1.28 \\
\hline & 10-year & 5,994 & & 326.66 & & 325.44 & & -1.22 \\
\hline & 2-year & 10,239 & & 329.46 & & 328.26 & & -1.2 \\
\hline \multirow{4}{*}{$\mathrm{DE}$} & 10-year & 5,994 & & 323.3 & & 320.5 & & -2.8 \\
\hline & 2-year & 10,239 & & 325.06 & & 322.99 & & -2.07 \\
\hline & 1-year & 12,576 & & 325.97 & & 324.09 & & -1.88 \\
\hline & 0.2 -year & 19,583 & & 328.28 & & 326.71 & & -1.57 \\
\hline \multirow[t]{5}{*}{$\mathrm{DD}$} & 50-year & 2,854 & 311.42 & 315.35 & 308.44 & 315.59 & -2.98 & 0.24 \\
\hline & 10-year & 5,994 & & 317.92 & & 318.1 & & 0.18 \\
\hline & 2-year & 10,239 & & 320.48 & & 320.63 & & 0.15 \\
\hline & 1-year & 12,576 & & 321.54 & & 321.72 & & 0.18 \\
\hline & 0.2 -year & 19,583 & & 323.96 & & 324.25 & & 0.29 \\
\hline \multirow[t]{5}{*}{$\mathrm{DB}$} & 50-year & 2,854 & 304.28 & 313.53 & 305.02 & 312.8 & 0.74 & -0.73 \\
\hline & 10-year & 5,994 & & 316.6 & & 315.96 & & -0.64 \\
\hline & 2-year & 10,239 & & 319.37 & & 318.78 & & -0.59 \\
\hline & 1-year & 12,576 & & 320.46 & & 319.93 & & -0.53 \\
\hline & 0.2 -year & 19,583 & & 322.83 & & 322.43 & & -0.4 \\
\hline \multirow[t]{5}{*}{ DA } & 50-year & 2,854 & 306.36 & 313.36 & 306.89 & 312.32 & 0.53 & -1.04 \\
\hline & 10 -year & 5,994 & & 316.33 & & 315.45 & & -0.88 \\
\hline & 2-year & 10,239 & & 319.02 & & 318.21 & & -0.81 \\
\hline & 1-year & 12,576 & & 320.11 & & 319.32 & & -0.79 \\
\hline & 0.2 -year & 19,583 & & 322.61 & & 321.98 & & -0.63 \\
\hline \multirow[t]{5}{*}{$\mathrm{CZ}$} & 50-year & 2,854 & 306.19 & 313.07 & 303.93 & 312.25 & -2.26 & -0.82 \\
\hline & 10-year & 5,994 & & 315.98 & & 315.35 & & -0.63 \\
\hline & 2-year & 10,239 & & 318.49 & & 318.03 & & -0.46 \\
\hline & 1-year & 12,576 & & 319.46 & & 319.09 & & -0.37 \\
\hline & 0.2 -year & 19,583 & & 321.89 & & 321.55 & & -0.34 \\
\hline
\end{tabular}


Table 7. Comparison of Hydrologic Engineering Center-River Analysis System (HEC-RAS)-predicted flood elevations for 2008 and the end of water year 2010 for the 50-, 10-, 2-, 1-, and 0.2-percent annual exceedence probability floods and streambed elevations at each cross section.-Continued

[Location of cross sections A-DW are shown in figure 4. WY, water year; \%, percent; $\mathrm{ft}^{3} / \mathrm{s}$, cubic feet per second; ft, feet; NGVD 29, National Geodetic Vertical Datum of 1929]

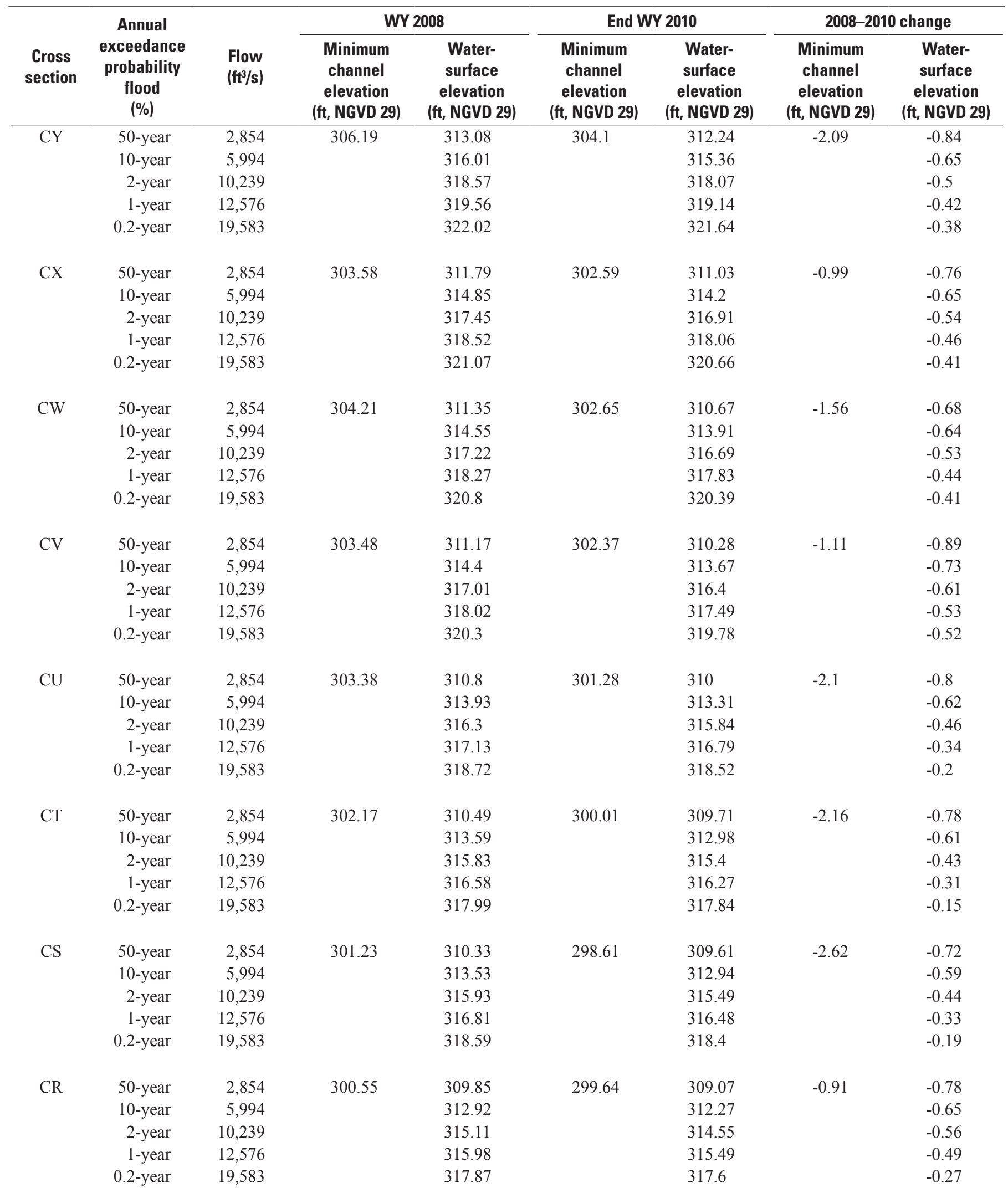


Table 7. Comparison of Hydrologic Engineering Center-River Analysis System (HEC-RAS)-predicted flood elevations for 2008 and the end of water year 2010 for the 50-, 10-, 2-, 1-, and 0.2-percent annual exceedence probability floods and streambed elevations at each cross section.-Continued

[Location of cross sections A-DW are shown in figure 4. WY, water year; \%, percent; $\mathrm{ft}^{3} / \mathrm{s}$, cubic feet per second; ft, feet; NGVD 29, National Geodetic Vertical Datum of 1929]

\begin{tabular}{|c|c|c|c|c|c|c|c|c|}
\hline \multirow[b]{2}{*}{$\begin{array}{c}\text { Cross } \\
\text { section }\end{array}$} & \multirow{2}{*}{$\begin{array}{l}\text { Annual } \\
\text { exceedance } \\
\text { probability } \\
\text { flood } \\
(\%)\end{array}$} & \multirow[b]{2}{*}{$\begin{array}{l}\text { Flow } \\
\left(\mathrm{ft}^{3} / \mathrm{s}\right)\end{array}$} & \multicolumn{2}{|c|}{ WY 2008} & \multicolumn{2}{|c|}{ End WY 2010} & \multicolumn{2}{|c|}{ 2008-2010 change } \\
\hline & & & $\begin{array}{c}\text { Minimum } \\
\text { channel } \\
\text { elevation } \\
\text { (ft, NGVD 29) }\end{array}$ & $\begin{array}{c}\text { Water- } \\
\text { surface } \\
\text { elevation } \\
\text { (ft, NGVD 29) }\end{array}$ & $\begin{array}{l}\text { Minimum } \\
\text { channel } \\
\text { elevation } \\
\text { (ft, NGVD 29) }\end{array}$ & $\begin{array}{c}\text { Water- } \\
\text { surface } \\
\text { elevation } \\
\text { (ft, NGVD 29) }\end{array}$ & $\begin{array}{c}\text { Minimum } \\
\text { channel } \\
\text { elevation } \\
\text { (ft, NGVD 29) }\end{array}$ & $\begin{array}{c}\text { Water- } \\
\text { surface } \\
\text { elevation } \\
\text { (ft, NGVD 29) }\end{array}$ \\
\hline \multirow[t]{3}{*}{ CQ } & 50-year & 2,854 & 299.49 & 309.2 & 296.72 & 308.77 & -2.77 & -0.43 \\
\hline & 10-year & 5,994 & & 311.98 & & 311.76 & & -0.22 \\
\hline & 0.2 -year & 19,583 & & 317.03 & & 316.84 & & -0.19 \\
\hline \multirow[t]{3}{*}{$\mathrm{CP}$} & 50-year & 2,854 & 299.17 & 308.58 & 299.92 & 307.93 & 0.75 & -0.65 \\
\hline & 10-year & 5,994 & & 311.2 & & 310.6 & & -0.6 \\
\hline & 2-year & 10,239 & & 312.77 & & 312.32 & & -0.45 \\
\hline \multirow{4}{*}{$\mathrm{CO}$} & 10-year & 5,994 & & 310.09 & & 309.56 & & -0.53 \\
\hline & 2-year & 10,239 & & 311.27 & & 310.94 & & -0.33 \\
\hline & 1-year & 12,576 & & 311.82 & & 311.75 & & -0.07 \\
\hline & 0.2 -year & 19,583 & & 315.41 & & 315.24 & & -0.17 \\
\hline \multirow[t]{5}{*}{$\mathrm{CN}$} & 50-year & 2,854 & 298.38 & 305.06 & 298.66 & 305.68 & 0.28 & 0.62 \\
\hline & 10-year & 5,994 & & 306.02 & & 306.66 & & 0.64 \\
\hline & 2-year & 10,239 & & 308.68 & & 309.06 & & 0.38 \\
\hline & 1-year & 12,576 & & 310.58 & & 310.73 & & 0.15 \\
\hline & 0.2 -year & 19,583 & & 315.1 & & 314.94 & & -0.16 \\
\hline \multirow[t]{5}{*}{$\mathrm{CL}$} & 50-year & 2,854 & 296.75 & 303.61 & 296.48 & 304.19 & -0.27 & 0.58 \\
\hline & 10-year & 5,994 & & 305.38 & & 305.8 & & 0.42 \\
\hline & 2-year & 10,239 & & 308.72 & & 308.91 & & 0.19 \\
\hline & 1-year & 12,576 & & 310.55 & & 310.66 & & 0.11 \\
\hline & 0.2 -year & 19,583 & & 315.12 & & 314.94 & & -0.18 \\
\hline \multirow[t]{5}{*}{$\mathrm{CK}$} & 50 -year & 2,854 & 296.2 & 302.75 & 297.1 & 303.38 & 0.9 & 0.63 \\
\hline & 10 -year & 5,994 & & 304.87 & & 305.25 & & 0.38 \\
\hline & 2-year & 10,239 & & 308.59 & & 308.77 & & 0.18 \\
\hline & 1-year & 12,576 & & 310.47 & & 310.56 & & 0.09 \\
\hline & 0.2 -year & 19,583 & & 315.08 & & 314.89 & & -0.19 \\
\hline \multirow[t]{5}{*}{$\mathrm{CJ}$} & 50-year & 2,854 & 296.17 & 302.54 & 295.92 & 303.02 & -0.25 & 0.48 \\
\hline & 10-year & 5,994 & & 304.8 & & 305.13 & & 0.33 \\
\hline & 2-year & 10,239 & & 308.58 & & 308.76 & & 0.18 \\
\hline & 1-year & 12,576 & & 310.47 & & 310.56 & & 0.09 \\
\hline & 0.2 -year & 19,583 & & 315.08 & & 314.9 & & -0.18 \\
\hline
\end{tabular}


Table 7. Comparison of Hydrologic Engineering Center-River Analysis System (HEC-RAS)-predicted flood elevations for 2008 and the end of water year 2010 for the 50-, 10-, 2-, 1-, and 0.2-percent annual exceedence probability floods and streambed elevations at each cross section.-Continued

[Location of cross sections A-DW are shown in figure 4. WY, water year; \%, percent; $\mathrm{ft}^{3} / \mathrm{s}$, cubic feet per second; ft, feet; NGVD 29, National Geodetic Vertical Datum of 1929]

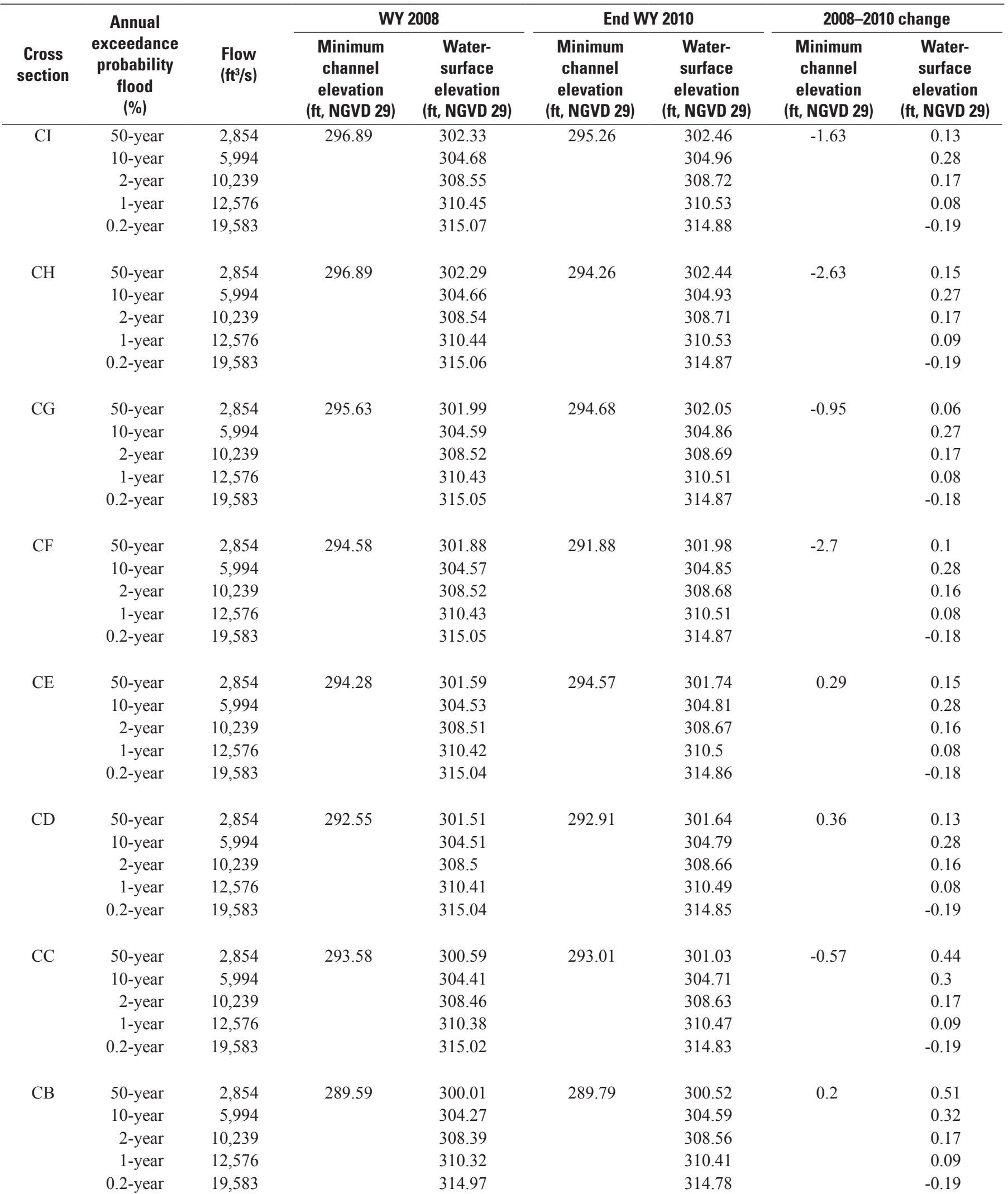


Table 7. Comparison of Hydrologic Engineering Center-River Analysis System (HEC-RAS)-predicted flood elevations for 2008 and the end of water year 2010 for the 50-, 10-, 2-, 1-, and 0.2-percent annual exceedence probability floods and streambed elevations at each cross section.-Continued

[Location of cross sections A-DW are shown in figure 4. WY, water year; \%, percent; $\mathrm{ft}^{3} / \mathrm{s}$, cubic feet per second; ft, feet; NGVD 29, National Geodetic Vertical Datum of 1929]

\begin{tabular}{|c|c|c|c|c|c|c|c|c|}
\hline \multirow[b]{2}{*}{$\begin{array}{c}\text { Cross } \\
\text { section }\end{array}$} & \multirow{2}{*}{$\begin{array}{l}\text { Annual } \\
\text { exceedance } \\
\text { probability } \\
\text { flood } \\
(\%)\end{array}$} & \multirow[b]{2}{*}{$\begin{array}{l}\text { Flow } \\
\left(\mathrm{ft}^{3} / \mathrm{s}\right)\end{array}$} & \multicolumn{2}{|c|}{ WY 2008} & \multicolumn{2}{|c|}{ End WY 2010} & \multicolumn{2}{|c|}{ 2008-2010 change } \\
\hline & & & $\begin{array}{l}\text { Minimum } \\
\text { channel } \\
\text { elevation } \\
\text { (ft, NGVD 29) }\end{array}$ & $\begin{array}{c}\text { Water- } \\
\text { surface } \\
\text { elevation } \\
\text { (ft, NGVD 29) }\end{array}$ & $\begin{array}{c}\text { Minimum } \\
\text { channel } \\
\text { elevation } \\
\text { (ft, NGVD 29) }\end{array}$ & $\begin{array}{c}\text { Water- } \\
\text { surface } \\
\text { elevation } \\
\text { (ft, NGVD 29) }\end{array}$ & $\begin{array}{l}\text { Minimum } \\
\text { channel } \\
\text { elevation } \\
\text { (ft, NGVD 29) }\end{array}$ & $\begin{array}{c}\text { Water- } \\
\text { surface } \\
\text { elevation } \\
\text { (ft, NGVD 29) }\end{array}$ \\
\hline \multirow[t]{3}{*}{$\mathrm{CA}$} & 50-year & 2,854 & 289.73 & 299.64 & 290.2 & 300.17 & 0.47 & 0.53 \\
\hline & 10-year & 5,994 & & 304.13 & & 304.45 & & 0.32 \\
\hline & 0.2-year & 19,583 & & 314.88 & & 314.68 & & -0.2 \\
\hline \multirow[t]{3}{*}{$\mathrm{BZ}$} & 50-year & 2,854 & 289.81 & 299.39 & 289.84 & 299.92 & 0.03 & 0.53 \\
\hline & 10-year & 5,994 & & 303.84 & & 304.17 & & 0.33 \\
\hline & 2-year & 10,239 & & 308.01 & & 308.18 & & 0.17 \\
\hline \multirow{4}{*}{ BY } & 10-year & 5,994 & & 303.22 & & 303.74 & & 0.52 \\
\hline & 2-year & 10,239 & & 307.3 & & 307.61 & & 0.31 \\
\hline & 1-year & 12,576 & & 309.19 & & 309.4 & & 0.21 \\
\hline & 0.2 -year & 19,583 & & 313.69 & & 313.56 & & -0.13 \\
\hline \multirow[t]{5}{*}{$\mathrm{BX}$} & 50-year & 2,976 & 287.32 & 298.4 & 288.67 & 299.15 & 1.35 & 0.75 \\
\hline & 10-year & 6,252 & & 302.71 & & 303.29 & & 0.58 \\
\hline & 2-year & 10,679 & & 306.52 & & 306.98 & & 0.46 \\
\hline & 1-year & 13,117 & & 308.28 & & 308.66 & & 0.38 \\
\hline & 0.2 -year & 20,425 & & 311.95 & & 312.24 & & 0.29 \\
\hline \multirow{2}{*}{ BW } & 1-year & 13,117 & & 308.38 & & 308.8 & & 0.42 \\
\hline & 0.2 -year & 20,425 & & 312.09 & & 312.44 & & 0.35 \\
\hline \multirow[t]{5}{*}{ BV } & 50-year & 2,976 & 286.8 & 298.37 & 284.86 & 299.22 & -1.94 & 0.85 \\
\hline & 10-year & 6,252 & & 302.69 & & 303.37 & & 0.68 \\
\hline & 2-year & 10,679 & & 306.53 & & 307.08 & & 0.55 \\
\hline & 1-year & 13,117 & & 308.31 & & 308.77 & & 0.46 \\
\hline & 0.2 -year & 20,425 & & 312.02 & & 312.4 & & 0.38 \\
\hline \multirow[t]{5}{*}{$\mathrm{BU}$} & 50-year & 2,976 & 285.85 & 298.22 & 287.99 & 299.03 & 2.14 & 0.81 \\
\hline & 10 -year & 6,252 & & 302.47 & & 303.09 & & 0.62 \\
\hline & 2-year & 10,679 & & 306.22 & & 306.7 & & 0.48 \\
\hline & 1-year & 13,117 & & 307.96 & & 308.36 & & 0.4 \\
\hline & 0.2-year & 20,425 & & 311.58 & & 311.91 & & 0.33 \\
\hline \multirow[t]{5}{*}{ BT } & 50-year & 2,976 & 282.55 & 297.77 & 283.89 & 298.39 & 1.34 & 0.62 \\
\hline & 10 -year & 6,252 & & 301.9 & & 302.4 & & 0.5 \\
\hline & 2-year & 10,679 & & 305.61 & & 306.02 & & 0.41 \\
\hline & 1-year & 13,117 & & 307.37 & & 307.69 & & 0.32 \\
\hline & 0.2 -year & 20,425 & & 310.94 & & 311.22 & & 0.28 \\
\hline
\end{tabular}


Table 7. Comparison of Hydrologic Engineering Center-River Analysis System (HEC-RAS)-predicted flood elevations for 2008 and the end of water year 2010 for the 50-, 10-, 2-, 1-, and 0.2-percent annual exceedence probability floods and streambed elevations at each cross section.-Continued

[Location of cross sections A-DW are shown in figure 4. WY, water year; \%, percent; $\mathrm{ft}^{3} / \mathrm{s}$, cubic feet per second; ft, feet; NGVD 29, National Geodetic Vertical Datum of 1929]

\begin{tabular}{|c|c|c|c|c|c|c|c|c|}
\hline \multirow[b]{2}{*}{$\begin{array}{c}\text { Cross } \\
\text { section }\end{array}$} & \multirow{2}{*}{$\begin{array}{l}\text { Annual } \\
\text { exceedance } \\
\text { probability } \\
\text { flood } \\
(\%)\end{array}$} & \multirow[b]{2}{*}{$\begin{array}{l}\text { Flow } \\
\left(\mathrm{ft}^{3} / \mathrm{s}\right)\end{array}$} & \multicolumn{2}{|c|}{ WY 2008} & \multicolumn{2}{|c|}{ End WY 2010} & \multicolumn{2}{|c|}{ 2008-2010 change } \\
\hline & & & $\begin{array}{c}\text { Minimum } \\
\text { channel } \\
\text { elevation } \\
\text { (ft, NGVD 29) }\end{array}$ & $\begin{array}{c}\text { Water- } \\
\text { surface } \\
\text { elevation } \\
\text { (ft, NGVD 29) }\end{array}$ & $\begin{array}{c}\text { Minimum } \\
\text { channel } \\
\text { elevation } \\
\text { (ft, NGVD 29) }\end{array}$ & $\begin{array}{c}\text { Water- } \\
\text { surface } \\
\text { elevation } \\
\text { (ft, NGVD 29) }\end{array}$ & $\begin{array}{c}\text { Minimum } \\
\text { channel } \\
\text { elevation } \\
\text { (ft, NGVD 29) }\end{array}$ & $\begin{array}{c}\text { Water- } \\
\text { surface } \\
\text { elevation } \\
\text { (ft, NGVD 29) }\end{array}$ \\
\hline \multirow[t]{3}{*}{$\mathrm{BS}$} & 50-year & 2,976 & 283.65 & 297.54 & 286.69 & 297.98 & 3.04 & 0.44 \\
\hline & 10-year & 6,252 & & 301.59 & & 301.94 & & 0.35 \\
\hline & 0.2 -year & 20,425 & & 310.54 & & 310.7 & & 0.16 \\
\hline \multirow[t]{3}{*}{$\mathrm{BR}$} & 50-year & 2,976 & 286.45 & 297.37 & 287.6 & 297.73 & 1.15 & 0.36 \\
\hline & 10-year & 6,252 & & 301.46 & & 301.8 & & 0.34 \\
\hline & 2-year & 10,679 & & 305.21 & & 305.49 & & 0.28 \\
\hline \multirow{4}{*}{ BQ } & 10-year & 6,252 & & 301.26 & & 301.52 & & 0.26 \\
\hline & 2-year & 10,679 & & 304.93 & & 305.15 & & 0.22 \\
\hline & 1-year & 13,117 & & 306.7 & & 306.86 & & 0.16 \\
\hline & 0.2 -year & 20,425 & & 310.26 & & 310.41 & & 0.15 \\
\hline \multirow[t]{5}{*}{$\mathrm{BP}$} & 50-year & 2,976 & 286.15 & 297.07 & 286.72 & 297.33 & 0.57 & 0.26 \\
\hline & 10-year & 6,252 & & 300.97 & & 301.23 & & 0.26 \\
\hline & 2-year & 10,679 & & 304.51 & & 304.72 & & 0.21 \\
\hline & 1-year & 13,117 & & 306.24 & & 306.39 & & 0.15 \\
\hline & 0.2 -year & 20,425 & & 309.76 & & 309.92 & & 0.16 \\
\hline \multirow[t]{5}{*}{$\mathrm{BN}$} & 50-year & 2,976 & 286.48 & 296.84 & 285.86 & 297.06 & -0.62 & 0.22 \\
\hline & 10 -year & 6,252 & & 300.56 & & 300.81 & & 0.25 \\
\hline & 2-year & 10,679 & & 304.07 & & 304.29 & & 0.22 \\
\hline & 1-year & 13,117 & & 305.87 & & 306.02 & & 0.15 \\
\hline & 0.2 -year & 20,425 & & 309.39 & & 309.51 & & 0.12 \\
\hline \multirow[t]{5}{*}{$\mathrm{BM}$} & 50-year & 2,976 & 285.93 & 296.71 & 285.82 & 296.94 & -0.11 & 0.23 \\
\hline & 10 -year & 6,252 & & 300.34 & & 300.6 & & 0.26 \\
\hline & 2-year & 10,679 & & 303.72 & & 303.95 & & 0.23 \\
\hline & 1-year & 13,117 & & 305.48 & & 305.64 & & 0.16 \\
\hline & 0.2 -year & 20,425 & & 308.99 & & 309.13 & & 0.14 \\
\hline \multirow[t]{5}{*}{ BL } & 50-year & 2,976 & 279.7 & 296.5 & 280.87 & 296.69 & 1.17 & 0.19 \\
\hline & 10-year & 6,252 & & 300.06 & & 300.26 & & 0.2 \\
\hline & 2-year & 10,679 & & 303.39 & & 303.55 & & 0.16 \\
\hline & 1-year & 13,117 & & 305.17 & & 305.26 & & 0.09 \\
\hline & 0.2 -year & 20,425 & & 308.68 & & 308.77 & & 0.09 \\
\hline
\end{tabular}


Table 7. Comparison of Hydrologic Engineering Center-River Analysis System (HEC-RAS)-predicted flood elevations for 2008 and the end of water year 2010 for the 50-, 10-, 2-, 1-, and 0.2-percent annual exceedence probability floods and streambed elevations at each cross section.-Continued

[Location of cross sections A-DW are shown in figure 4. WY, water year; \%, percent; $\mathrm{ft}^{3} / \mathrm{s}$, cubic feet per second; ft, feet; NGVD 29, National Geodetic Vertical Datum of 1929]

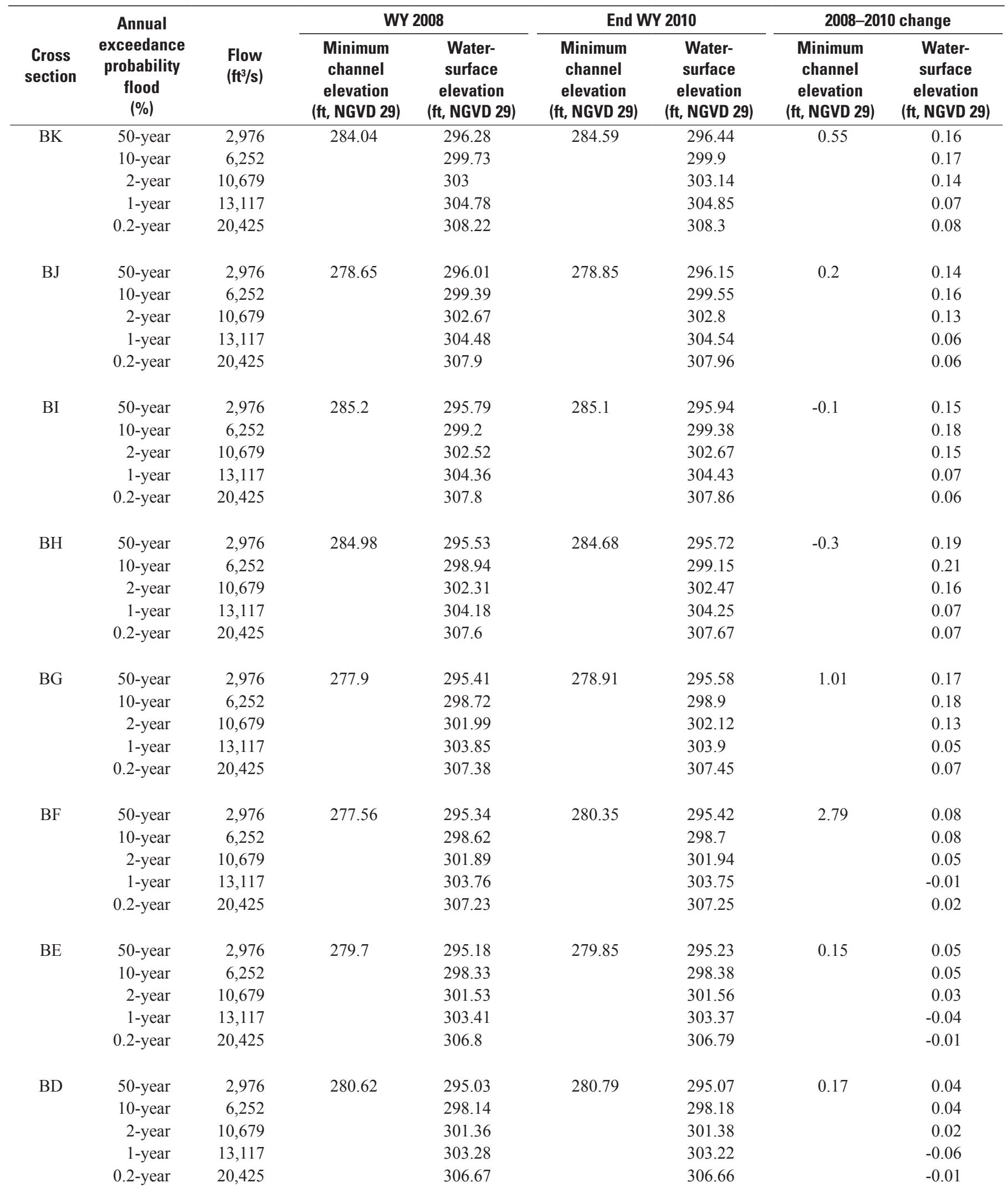


Table 7. Comparison of Hydrologic Engineering Center-River Analysis System (HEC-RAS)-predicted flood elevations for 2008 and the end of water year 2010 for the 50-, 10-, 2-, 1-, and 0.2-percent annual exceedence probability floods and streambed elevations at each cross section.-Continued

[Location of cross sections A-DW are shown in figure 4. WY, water year; \%, percent; $\mathrm{ft}^{3} / \mathrm{s}$, cubic feet per second; ft, feet; NGVD 29, National Geodetic Vertical Datum of 1929]

\begin{tabular}{|c|c|c|c|c|c|c|c|c|}
\hline \multirow[b]{2}{*}{$\begin{array}{c}\text { Cross } \\
\text { section }\end{array}$} & \multirow{2}{*}{$\begin{array}{l}\text { Annual } \\
\text { exceedance } \\
\text { probability } \\
\text { flood } \\
(\%)\end{array}$} & \multirow[b]{2}{*}{$\begin{array}{l}\text { Flow } \\
\left(\mathrm{ft}^{3} / \mathrm{s}\right)\end{array}$} & \multicolumn{2}{|c|}{ WY 2008} & \multicolumn{2}{|c|}{ End WY 2010} & \multicolumn{2}{|c|}{ 2008-2010 change } \\
\hline & & & $\begin{array}{c}\text { Minimum } \\
\text { channel } \\
\text { elevation } \\
\text { (ft, NGVD 29) }\end{array}$ & $\begin{array}{c}\text { Water- } \\
\text { surface } \\
\text { elevation } \\
\text { (ft, NGVD 29) }\end{array}$ & $\begin{array}{c}\text { Minimum } \\
\text { channel } \\
\text { elevation } \\
\text { (ft, NGVD 29) }\end{array}$ & $\begin{array}{c}\text { Water- } \\
\text { surface } \\
\text { elevation } \\
\text { (ft, NGVD 29) }\end{array}$ & $\begin{array}{c}\text { Minimum } \\
\text { channel } \\
\text { elevation } \\
\text { (ft, NGVD 29) }\end{array}$ & $\begin{array}{c}\text { Water- } \\
\text { surface } \\
\text { elevation } \\
\text { (ft, NGVD 29) }\end{array}$ \\
\hline \multirow[t]{3}{*}{$\mathrm{BC}$} & 50-year & 2,976 & 275.28 & 294.85 & 276.45 & 294.82 & 1.17 & -0.03 \\
\hline & 10-year & 6,252 & & 297.77 & & 297.73 & & -0.04 \\
\hline & 0.2 -year & 20,425 & & 306.06 & & 305.97 & & -0.09 \\
\hline \multirow[t]{3}{*}{$\mathrm{BB}$} & 50-year & 2,976 & 278.99 & 294.75 & 280.15 & 294.68 & 1.16 & -0.07 \\
\hline & 10-year & 6,252 & & 297.55 & & 297.43 & & -0.12 \\
\hline & 2-year & 10,679 & & 300.55 & & 300.39 & & -0.16 \\
\hline \multirow{4}{*}{$\mathrm{BA}$} & 10-year & 6,509 & & 297.46 & & 297.38 & & -0.08 \\
\hline & 2-year & 11,118 & & 300.41 & & 300.3 & & -0.11 \\
\hline & 1-year & 13,656 & & 302.33 & & 302.16 & & -0.17 \\
\hline & 0.2 -year & 21,265 & & 305.61 & & 305.51 & & -0.1 \\
\hline \multirow[t]{5}{*}{$\mathrm{AZ}$} & 50-year & 3,325 & 277.09 & 294.58 & 276.12 & 294.55 & -0.97 & -0.03 \\
\hline & 10-year & 6,985 & & 297.13 & & 297.1 & & -0.03 \\
\hline & 2-year & 11,931 & & 299.92 & & 299.86 & & -0.06 \\
\hline & 1-year & 14,654 & & 301.85 & & 301.71 & & -0.14 \\
\hline & 0.2 -year & 22,820 & & 304.99 & & 304.93 & & -0.06 \\
\hline \multirow[t]{5}{*}{$\mathrm{AX}$} & 50-year & 3,325 & 276.47 & 294.46 & 276.45 & 294.45 & -0.02 & -0.01 \\
\hline & 10 -year & 6,985 & & 296.89 & & 296.86 & & -0.03 \\
\hline & 2-year & 11,931 & & 299.58 & & 299.52 & & -0.06 \\
\hline & 1-year & 14,654 & & 301.55 & & 301.39 & & -0.16 \\
\hline & 0.2 -year & 22,820 & & 304.58 & & 304.51 & & -0.07 \\
\hline \multirow[t]{5}{*}{ AW } & 50-year & 3,325 & 276.97 & 294.39 & 276.93 & 294.37 & -0.04 & -0.02 \\
\hline & 10 -year & 6,985 & & 296.7 & & 296.67 & & -0.03 \\
\hline & 2-year & 11,931 & & 299.37 & & 299.31 & & -0.06 \\
\hline & 1-year & 14,654 & & 301.39 & & 301.22 & & -0.17 \\
\hline & 0.2 -year & 22,820 & & 304.42 & & 304.35 & & -0.07 \\
\hline \multirow[t]{5}{*}{ AV } & 50-year & 3,325 & 279.32 & 294.31 & 279.14 & 294.3 & -0.18 & -0.01 \\
\hline & 10 -year & 6,985 & & 296.51 & & 296.49 & & -0.02 \\
\hline & 2-year & 11,931 & & 298.99 & & 298.93 & & -0.06 \\
\hline & 1-year & 14,654 & & 300.93 & & 300.77 & & -0.16 \\
\hline & 0.2 -year & 22,820 & & 303.57 & & 303.51 & & -0.06 \\
\hline
\end{tabular}


Table 7. Comparison of Hydrologic Engineering Center-River Analysis System (HEC-RAS)-predicted flood elevations for 2008 and the end of water year 2010 for the 50-, 10-, 2-, 1-, and 0.2-percent annual exceedence probability floods and streambed elevations at each cross section.-Continued

[Location of cross sections A-DW are shown in figure 4. WY, water year; \%, percent; $\mathrm{ft}^{3} / \mathrm{s}$, cubic feet per second; ft, feet; NGVD 29, National Geodetic Vertical Datum of 1929]

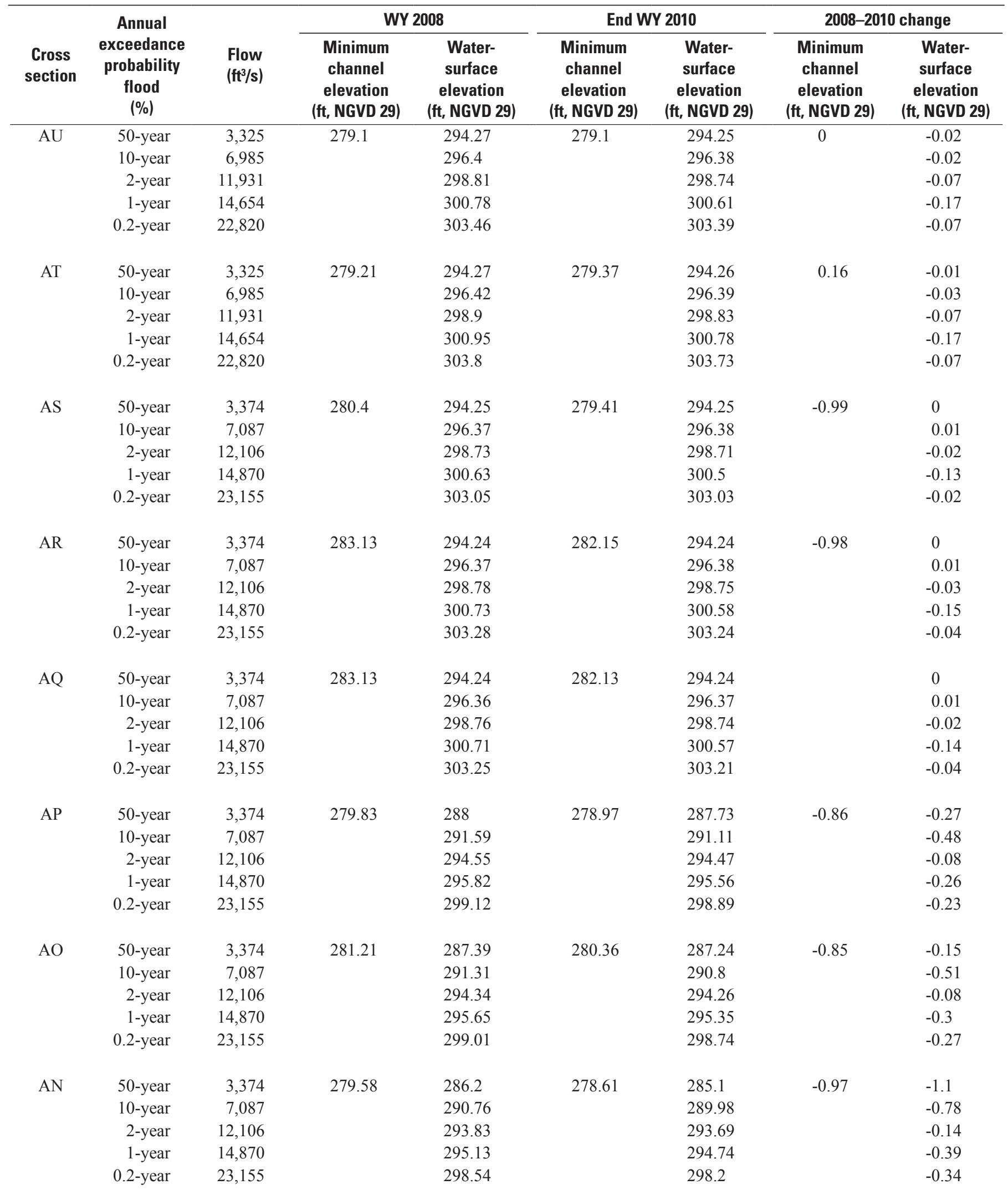


Table 7. Comparison of Hydrologic Engineering Center-River Analysis System (HEC-RAS)-predicted flood elevations for 2008 and the end of water year 2010 for the 50-, 10-, 2-, 1-, and 0.2-percent annual exceedence probability floods and streambed elevations at each cross section.-Continued

[Location of cross sections A-DW are shown in figure 4. WY, water year; \%, percent; $\mathrm{ft}^{3} / \mathrm{s}$, cubic feet per second; ft, feet; NGVD 29, National Geodetic Vertical Datum of 1929]

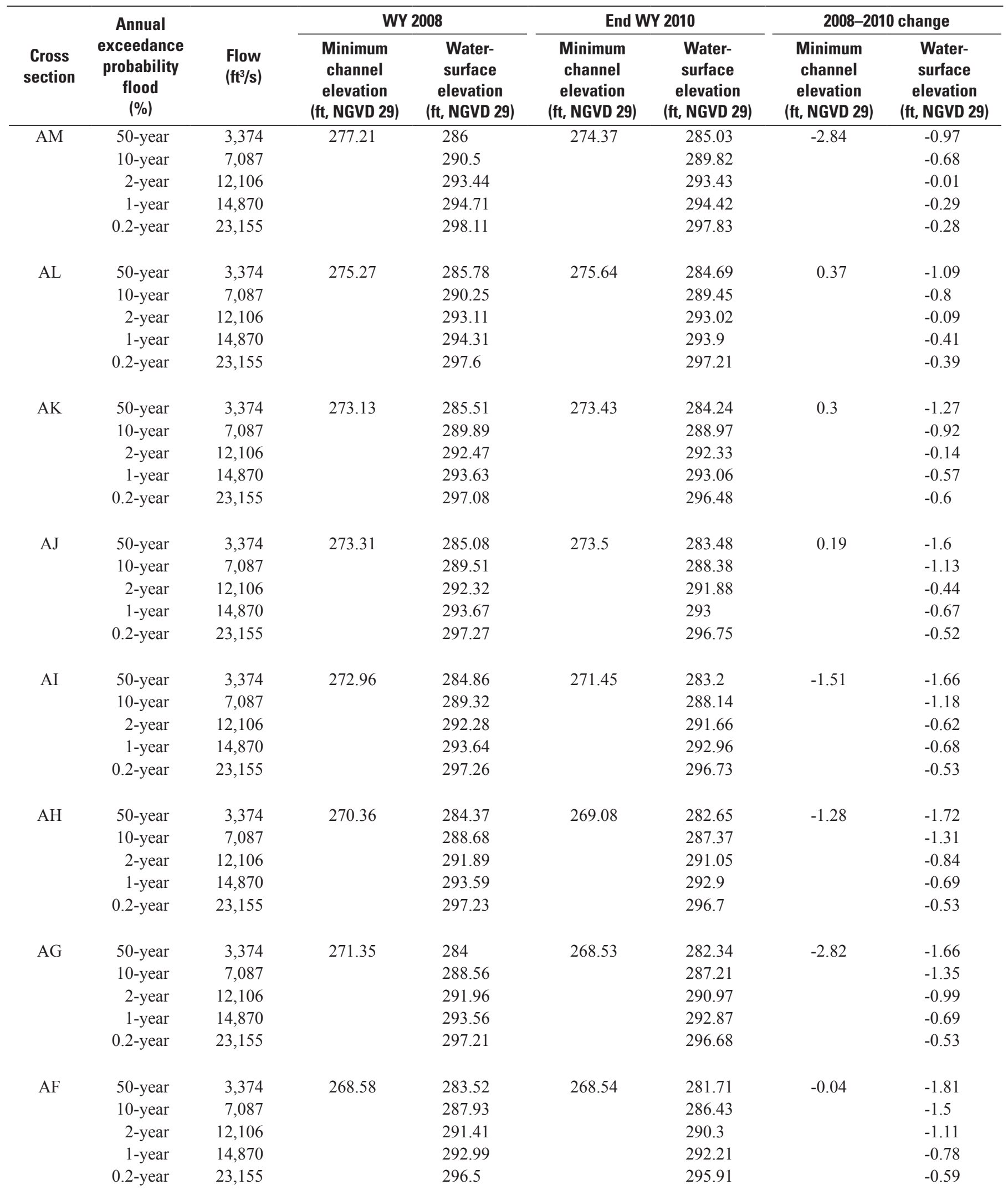


Table 7. Comparison of Hydrologic Engineering Center-River Analysis System (HEC-RAS)-predicted flood elevations for 2008 and the end of water year 2010 for the 50-, 10-, 2-, 1-, and 0.2-percent annual exceedence probability floods and streambed elevations at each cross section.-Continued

[Location of cross sections A-DW are shown in figure 4. WY, water year; \%, percent; $\mathrm{ft}^{3} / \mathrm{s}$, cubic feet per second; ft, feet; NGVD 29, National Geodetic Vertical Datum of 1929]

\begin{tabular}{|c|c|c|c|c|c|c|c|c|}
\hline \multirow[b]{2}{*}{$\begin{array}{c}\text { Cross } \\
\text { section }\end{array}$} & \multirow{2}{*}{$\begin{array}{l}\text { Annual } \\
\text { exceedance } \\
\text { probability } \\
\text { flood } \\
(\%)\end{array}$} & \multirow[b]{2}{*}{$\begin{array}{l}\text { Flow } \\
\left(\mathrm{ft}^{3} / \mathrm{s}\right)\end{array}$} & \multicolumn{2}{|c|}{ WY 2008} & \multicolumn{2}{|c|}{ End WY 2010} & \multicolumn{2}{|c|}{ 2008-2010 change } \\
\hline & & & $\begin{array}{l}\text { Minimum } \\
\text { channel } \\
\text { elevation } \\
\text { (ft, NGVD 29) }\end{array}$ & $\begin{array}{c}\text { Water- } \\
\text { surface } \\
\text { elevation } \\
\text { (ft, NGVD 29) }\end{array}$ & $\begin{array}{c}\text { Minimum } \\
\text { channel } \\
\text { elevation } \\
\text { (ft, NGVD 29) }\end{array}$ & $\begin{array}{c}\text { Water- } \\
\text { surface } \\
\text { elevation } \\
\text { (ft, NGVD 29) }\end{array}$ & $\begin{array}{c}\text { Minimum } \\
\text { channel } \\
\text { elevation } \\
\text { (ft, NGVD 29) }\end{array}$ & $\begin{array}{c}\text { Water- } \\
\text { surface } \\
\text { elevation } \\
\text { (ft, NGVD 29) }\end{array}$ \\
\hline \multirow[t]{3}{*}{$\mathrm{AE}$} & 50-year & 3,374 & 267.7 & 283.32 & 267.13 & 281.4 & -0.57 & -1.92 \\
\hline & 10-year & 7,087 & & 287.58 & & 285.97 & & -1.61 \\
\hline & 0.2-year & 23,155 & & 296.06 & & 295.42 & & -0.64 \\
\hline \multirow[t]{3}{*}{$\mathrm{AD}$} & 50-year & 3,374 & 266.9 & 282.96 & 266.52 & 280.85 & -0.38 & -2.11 \\
\hline & 10-year & 7,087 & & 287.08 & & 285.1 & & -1.98 \\
\hline & 2-year & 12,106 & & 290.74 & & 289.27 & & -1.47 \\
\hline \multirow{4}{*}{$\mathrm{AC}$} & 10-year & 7,087 & & 286.49 & & 284.45 & & -2.04 \\
\hline & 2-year & 12,106 & & 290.02 & & 288.47 & & -1.55 \\
\hline & 1-year & 14,870 & & 291.64 & & 290.7 & & -0.94 \\
\hline & 0.2 -year & 23,155 & & 295.21 & & 294.51 & & -0.7 \\
\hline \multirow[t]{5}{*}{$\mathrm{AB}$} & 50-year & 3,374 & 270.97 & 282.46 & 269.07 & 280.29 & -1.9 & -2.17 \\
\hline & 10-year & 7,087 & & 286.3 & & 284.26 & & -2.04 \\
\hline & 2-year & 12,106 & & 289.8 & & 288.25 & & -1.55 \\
\hline & 1-year & 14,870 & & 291.42 & & 290.5 & & -0.92 \\
\hline & 0.2 -year & 23,155 & & 294.94 & & 294.28 & & -0.66 \\
\hline \multirow[t]{5}{*}{$\mathrm{Z}$} & 50-year & 3,374 & 267.96 & 282.14 & 267.38 & 279.74 & -0.58 & -2.4 \\
\hline & 10 -year & 7,087 & & 285.67 & & 283.37 & & -2.3 \\
\hline & 2-year & 12,106 & & 289 & & 287.1 & & -1.9 \\
\hline & 1-year & 14,870 & & 290.76 & & 289.51 & & -1.25 \\
\hline & 0.2 -year & 23,155 & & 294.26 & & 293.49 & & -0.77 \\
\hline \multirow[t]{5}{*}{$\mathrm{Y}$} & 50-year & 3,374 & 270.26 & 281.73 & 267.27 & 279.31 & -2.99 & -2.42 \\
\hline & 10 -year & 7,087 & & 284.85 & & 282.61 & & -2.24 \\
\hline & 2-year & 12,106 & & 287.76 & & 285.92 & & -1.84 \\
\hline & 1-year & 14,870 & & 289.45 & & 288.37 & & -1.08 \\
\hline & 0.2-year & 23,155 & & 292.7 & & 292.12 & & -0.58 \\
\hline \multirow[t]{5}{*}{$\mathrm{X}$} & 50-year & 3,374 & 274.18 & 279.88 & 271.21 & 277.68 & -2.97 & -2.2 \\
\hline & 10 -year & 7,087 & & 281.75 & & 280.32 & & -1.43 \\
\hline & 2-year & 12,106 & & 283.7 & & 283.14 & & -0.56 \\
\hline & 1-year & 14,870 & & 286.8 & & 286.64 & & -0.16 \\
\hline & 0.2 -year & 23,155 & & 291.69 & & 291.23 & & -0.46 \\
\hline
\end{tabular}


Table 7. Comparison of Hydrologic Engineering Center-River Analysis System (HEC-RAS)-predicted flood elevations for 2008 and the end of water year 2010 for the 50-, 10-, 2-, 1-, and 0.2-percent annual exceedence probability floods and streambed elevations at each cross section.-Continued

[Location of cross sections A-DW are shown in figure 4. WY, water year; \%, percent; $\mathrm{ft}^{3} / \mathrm{s}$, cubic feet per second; ft, feet; NGVD 29, National Geodetic Vertical Datum of 1929]

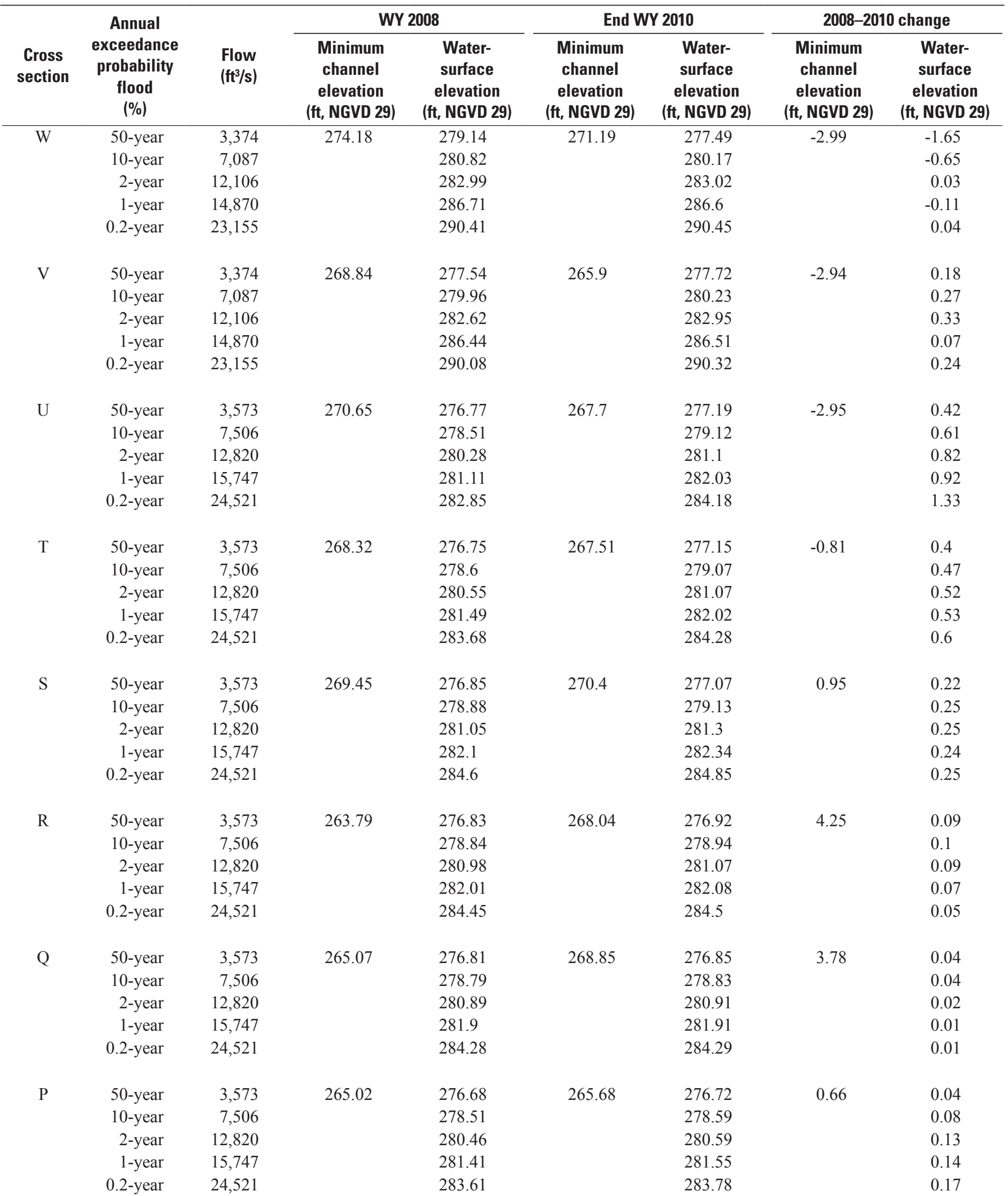


Table 7. Comparison of Hydrologic Engineering Center-River Analysis System (HEC-RAS)-predicted flood elevations for 2008 and the end of water year 2010 for the 50-, 10-, 2-, 1-, and 0.2-percent annual exceedence probability floods and streambed elevations at each cross section.-Continued

[Location of cross sections A-DW are shown in figure 4. WY, water year; \%, percent; $\mathrm{ft}^{3} / \mathrm{s}$, cubic feet per second; ft, feet; NGVD 29, National Geodetic Vertical Datum of 1929]

\begin{tabular}{|c|c|c|c|c|c|c|c|c|}
\hline \multirow[b]{2}{*}{$\begin{array}{c}\text { Cross } \\
\text { section }\end{array}$} & \multirow{2}{*}{$\begin{array}{l}\text { Annual } \\
\text { exceedance } \\
\text { probability } \\
\text { flood } \\
(\%)\end{array}$} & \multirow[b]{2}{*}{$\begin{array}{l}\text { Flow } \\
\left(\mathrm{ft}^{3} / \mathrm{s}\right)\end{array}$} & \multicolumn{2}{|c|}{ WY 2008} & \multicolumn{2}{|c|}{ End WY 2010} & \multicolumn{2}{|c|}{ 2008-2010 change } \\
\hline & & & $\begin{array}{c}\text { Minimum } \\
\text { channel } \\
\text { elevation } \\
\text { (ft, NGVD 29) }\end{array}$ & $\begin{array}{c}\text { Water- } \\
\text { surface } \\
\text { elevation } \\
\text { (ft, NGVD 29) }\end{array}$ & $\begin{array}{l}\text { Minimum } \\
\text { channel } \\
\text { elevation } \\
\text { (ft, NGVD 29) }\end{array}$ & $\begin{array}{c}\text { Water- } \\
\text { surface } \\
\text { elevation } \\
\text { (ft, NGVD 29) }\end{array}$ & $\begin{array}{c}\text { Minimum } \\
\text { channel } \\
\text { elevation } \\
\text { (ft, NGVD 29) }\end{array}$ & $\begin{array}{c}\text { Water- } \\
\text { surface } \\
\text { elevation } \\
\text { (ft, NGVD 29) }\end{array}$ \\
\hline \multirow[t]{3}{*}{$\mathrm{O}$} & 50-year & 3,573 & 263.45 & 276.66 & 265.65 & 276.63 & 2.2 & -0.03 \\
\hline & 10-year & 7,506 & & 278.41 & & 278.32 & & -0.09 \\
\hline & 0.2 -year & 24,521 & & 282.93 & & 282.6 & & -0.33 \\
\hline \multirow[t]{3}{*}{$\mathrm{N}$} & 50-year & 3,573 & 259.63 & 265.25 & 258.64 & 264.36 & -0.99 & -0.89 \\
\hline & 10-year & 7,506 & & 267.43 & & 266.7 & & -0.73 \\
\hline & 2-year & 12,820 & & 269.59 & & 268.94 & & -0.65 \\
\hline \multirow{4}{*}{ M } & 10 -year & 7,506 & & 266.27 & & 265.52 & & -0.75 \\
\hline & 2-year & 12,820 & & 268.42 & & 267.77 & & -0.65 \\
\hline & 1-year & 15,747 & & 269.44 & & 268.82 & & -0.62 \\
\hline & 0.2 -year & 24,521 & & 273.05 & & 272.58 & & -0.47 \\
\hline \multirow[t]{5}{*}{$\mathrm{L}$} & 50-year & 3,573 & 251.54 & 257.82 & 248.6 & 259.73 & -2.94 & 1.91 \\
\hline & 10-year & 7,506 & & 260.59 & & 262.03 & & 1.44 \\
\hline & 2-year & 12,820 & & 263.58 & & 264.27 & & 0.69 \\
\hline & 1-year & 15,747 & & 265.5 & & 265.53 & & 0.03 \\
\hline & 0.2 -year & 24,521 & & 274.59 & & 274.25 & & -0.34 \\
\hline \multirow[t]{5}{*}{$\mathrm{J}$} & 50-year & 3,573 & 242.2 & 254.09 & 239.2 & 252.28 & -3 & -1.81 \\
\hline & 10-year & 7,506 & & 256.47 & & 255.98 & & -0.49 \\
\hline & 2-year & 12,820 & & 261.1 & & 260.39 & & -0.71 \\
\hline & 1-year & 15,747 & & 263.7 & & 262.97 & & -0.73 \\
\hline & 0.2 -year & 24,521 & & 274.04 & & 273.61 & & -0.43 \\
\hline \multirow[t]{5}{*}{ I } & 50-year & 3,573 & 242.1 & 251.35 & 239.1 & 251.03 & -3 & -0.32 \\
\hline & 10 -year & 7,506 & & 256.21 & & 255.87 & & -0.34 \\
\hline & 2-year & 12,820 & & 261.07 & & 260.59 & & -0.48 \\
\hline & 1-year & 15,747 & & 263.51 & & 262.97 & & -0.54 \\
\hline & 0.2 -year & 24,521 & & 273.85 & & 273.46 & & -0.39 \\
\hline \multirow[t]{5}{*}{$\mathrm{H}$} & 50-year & 3,573 & 219.73 & 230.61 & 218.77 & 230.94 & -0.96 & 0.33 \\
\hline & 10 -year & 7,506 & & 233.26 & & 233.67 & & 0.41 \\
\hline & 2-year & 12,820 & & 235.84 & & 236.23 & & 0.39 \\
\hline & 1-year & 15,747 & & 236.61 & & 237.03 & & 0.42 \\
\hline & 0.2 -year & 24,521 & & 237.91 & & 238.54 & & 0.63 \\
\hline
\end{tabular}


Table 7. Comparison of Hydrologic Engineering Center-River Analysis System (HEC-RAS)-predicted flood elevations for 2008 and the end of water year 2010 for the 50-, 10-, 2-, 1-, and 0.2-percent annual exceedence probability floods and streambed elevations at each cross section.-Continued

[Location of cross sections A-DW are shown in figure 4. WY, water year; \%, percent; $\mathrm{ft}^{3} / \mathrm{s}$, cubic feet per second; ft, feet; NGVD 29, National Geodetic Vertical Datum of 1929]

\begin{tabular}{|c|c|c|c|c|c|c|c|c|}
\hline \multirow[b]{2}{*}{$\begin{array}{c}\text { Cross } \\
\text { section }\end{array}$} & \multirow{2}{*}{$\begin{array}{l}\text { Annual } \\
\text { exceedance } \\
\text { probability } \\
\text { flood } \\
(\%)\end{array}$} & \multirow[b]{2}{*}{$\begin{array}{l}\text { Flow } \\
\left(\mathrm{ft}^{3} / \mathrm{s}\right)\end{array}$} & \multicolumn{2}{|c|}{ WY 2008} & \multicolumn{2}{|c|}{ End WY 2010} & \multicolumn{2}{|c|}{ 2008-2010 change } \\
\hline & & & $\begin{array}{c}\text { Minimum } \\
\text { channel } \\
\text { elevation } \\
\text { (ft, NGVD 29) }\end{array}$ & $\begin{array}{c}\text { Water- } \\
\text { surface } \\
\text { elevation } \\
\text { (ft, NGVD 29) }\end{array}$ & $\begin{array}{c}\text { Minimum } \\
\text { channel } \\
\text { elevation } \\
\text { (ft, NGVD 29) }\end{array}$ & $\begin{array}{c}\text { Water- } \\
\text { surface } \\
\text { elevation } \\
\text { (ft, NGVD 29) }\end{array}$ & $\begin{array}{l}\text { Minimum } \\
\text { channel } \\
\text { elevation } \\
\text { (ft, NGVD 29) }\end{array}$ & $\begin{array}{c}\text { Water- } \\
\text { surface } \\
\text { elevation } \\
\text { (ft, NGVD 29) }\end{array}$ \\
\hline \multirow[t]{3}{*}{ G } & 50-year & 3,573 & 214.79 & 230.67 & 218.85 & 230.87 & 4.06 & 0.2 \\
\hline & 10 -year & 7,506 & & 233.46 & & 233.62 & & 0.16 \\
\hline & 0.2 -year & 24,521 & & 239.38 & & 239.09 & & -0.29 \\
\hline \multirow[t]{3}{*}{$\mathrm{F}$} & 50-year & 3,573 & 204.12 & 207.87 & 201.12 & 204.86 & -3 & -3.01 \\
\hline & 10 -year & 7,506 & & 209.56 & & 207.39 & & -2.17 \\
\hline & 2-year & 12,820 & & 211.36 & & 211.15 & & -0.21 \\
\hline \multirow{4}{*}{$\mathrm{E}$} & 10 -year & 7,506 & & 206.5 & & 205.85 & & -0.65 \\
\hline & 2-year & 12,820 & & 209.69 & & 210.04 & & 0.35 \\
\hline & 1-year & 15,747 & & 211.77 & & 212.06 & & 0.29 \\
\hline & 0.2 -year & 24,521 & & 220.33 & & 220.33 & & 0 \\
\hline \multirow[t]{5}{*}{$\mathrm{D}$} & 50-year & 3,573 & 196.62 & 200.32 & 193.62 & 197.44 & -3 & -2.88 \\
\hline & 10-year & 7,506 & & 201.59 & & 199.37 & & -2.22 \\
\hline & 2-year & 12,820 & & 202.98 & & 201.25 & & -1.73 \\
\hline & 1-year & 15,747 & & 203.68 & & 201.93 & & -1.75 \\
\hline & 0.2 -year & 24,521 & & 205.49 & & 203.77 & & -1.72 \\
\hline \multirow[t]{5}{*}{$\mathrm{B}$} & 50-year & 3,573 & 183.54 & 188.82 & 180.54 & 186.28 & -3 & * \\
\hline & 10-year & 7,506 & Backwater & 195.1 & & 188.61 & & $*$ \\
\hline & 2-year & 12,820 & Backwater & 197 & & 190.25 & & * \\
\hline & 1-year & 15,747 & Backwater & 198.3 & & 190.84 & & $*$ \\
\hline & 0.2 -year & 24,521 & Backwater & 205 & & 192.31 & & $*$ \\
\hline \multirow[t]{5}{*}{ A } & 50-year & 3,573 & 181.57 & 186.44 & 178.57 & 183.64 & -3 & $*$ \\
\hline & 10 -year & 7,506 & Backwater & 195.1 & & 186.42 & & $*$ \\
\hline & 2-year & 12,820 & Backwater & 197 & & 188.31 & & $*$ \\
\hline & 1-year & 15,747 & Backwater & 198.3 & & 188.89 & & * \\
\hline & 0.2 -year & 24,521 & Backwater & 205 & & 190.35 & & $*$ \\
\hline
\end{tabular}

"Water-surface elevation for cross-sections A,B,C not reported due to backwater effects from Merrimack River. 
Appendix 1. Particle-size gradation and median diameter $\left(d_{50}\right)$ of streambed sediment samples collected at 30 locations in the [coord dms, coordinates in degrees, minutes, seconds; ID, identification number; N, north; W, west; mm, millimeters; \%, percent; <, less than; m, meters;

\begin{tabular}{|c|c|c|c|c|c|c|c|c|c|c|c|}
\hline \multirow{2}{*}{$\begin{array}{c}\text { Site ID } \\
\text { (coord dms) }\end{array}$} & \multirow{2}{*}{ OId ID } & \multirow{2}{*}{$\begin{array}{l}\text { Latitude } \\
\text { (N) }\end{array}$} & \multirow{2}{*}{$\begin{array}{l}\text { Longitude } \\
\text { (W) }\end{array}$} & \multirow{2}{*}{$\underset{(\mathrm{mm})}{d_{50}}$} & \multirow{2}{*}{$\begin{array}{l}\boldsymbol{d}_{50} \text { sediment } \\
\text { class name }\end{array}$} & \multicolumn{6}{|c|}{ Particle size (mm) } \\
\hline & & & & & & $\%<63 \mathrm{~m}$ & $\%<125 \mathrm{~m}$ & $\%<250 \mathrm{~m}$ & $\%<500 \mathrm{~m}$ & $\%<1 \mathrm{~mm}$ & $\%<2 \mathrm{~mm}$ \\
\hline 431505071222401 & SRM-1L & & & 0.161 & Fine sand & 10 & 37 & 82 & 96 & 98 & 99 \\
\hline 431505071222401 & SRM-1C & $4315^{\prime} 05.3^{\prime \prime}$ & $-7122^{\prime} 24.5^{\prime \prime}$ & 1.857 & Very coarse sand & 0 & 1 & 5 & 22 & 38 & 52 \\
\hline 431505071222401 & SRM-1R & & & 0.163 & Fine sand & 10 & 34 & 86 & 99 & 100 & \\
\hline 431421071214101 & SRM-10L & & & 0.215 & Fine sand & 3 & 19 & 62 & 92 & 98 & 100 \\
\hline 431421071214101 & SRM-10C & $4314^{\prime} 21.4^{\prime \prime}$ & $-7121^{\prime} 40.6^{\prime \prime}$ & 0.667 & Coarse sand & 4 & 10 & 24 & 40 & 70 & 91 \\
\hline 431421071214101 & SRM-10R & & & 0.151 & Fine sand & 6 & 38 & 96 & 100 & & \\
\hline 431419071213801 & SRM-15L & & & 0.166 & Fine sand & 6 & 31 & 89 & 100 & & \\
\hline 431419071213801 & SRM-15C & $4314^{\prime} 19.2^{\prime \prime}$ & $-7121^{\prime} 38.1^{\prime \prime}$ & 3.1 & Very fine gravel & 0 & 1 & 3 & 8 & 20 & 37 \\
\hline 431419071213801 & SRM-15R & & & 0.385 & Medium sand & 6 & 18 & 43 & 56 & 60 & 64 \\
\hline 431340071212801 & SRM-70L & & & 0.14 & Fine sand & 13 & 45 & 87 & 97 & 99 & 100 \\
\hline 431340071212801 & SRM-70C & $4313^{\prime} 39.7^{\prime \prime}$ & $-7121^{\prime} 27.5^{\prime \prime}$ & 26 & Coarse gravel & 0 & 0 & 3 & 19 & 30 & 36 \\
\hline 431340071212801 & SRM-70R & & & 0.406 & Medium sand & 7 & 20 & 45 & 53 & 54 & 55 \\
\hline 431335071212601 & SRM-80L & & & 0.212 & Fine sand & 8 & 27 & 60 & 88 & 95 & 99 \\
\hline 431335071212601 & SRM-80C & $4313^{\prime} 34.7^{\prime \prime}$ & $-7121^{\prime} 25.8^{\prime \prime}$ & 109 & Small cobbles & 0 & 1 & 6 & 14 & 18 & 19 \\
\hline 431335071212601 & SRM-80R & & & 4 & Fine gravel & 6 & 16 & 31 & 42 & 45 & 48 \\
\hline 431313071212901 & SRM-100L & & & 1.067 & Very coarse sand & 2 & 5 & 16 & 30 & 49 & 64 \\
\hline 431313071212901 & SRM-100C & $4313^{\prime} 13.0^{\prime \prime}$ & $-7121^{\prime} 29.4^{\prime \prime}$ & $>180$ & Large cobbles & 0 & 0 & 0 & 0 & 1 & 1 \\
\hline 431313071212901 & SRM-100R & & & 58.818 & Very coarse gravel & 0 & 1 & 3 & 6 & 9 & 11 \\
\hline 431309071213101 & SRM-110L & & & 0.615 & Coarse sand & 3 & 6 & 19 & 44 & 70 & 83 \\
\hline 431309071213101 & SRM-110C & $4313^{\prime} 08.9^{\prime \prime}$ & $-7121^{\prime} 30.9^{\prime \prime}$ & 25.333 & Coarse gravel & 2 & 5 & 8 & 14 & 19 & 22 \\
\hline 431309071213101 & SRM-110R & & & 0.203 & Fine sand & 9 & 22 & 67 & 96 & 97 & 97 \\
\hline 431306071213001 & SRM-120L & & & 6.154 & Fine gravel & 0 & 1 & 3 & 8 & 20 & 27 \\
\hline 431306071213001 & SRM-120C & $4313^{\prime} 06.3^{\prime \prime}$ & $-7121^{\prime} 29.9^{\prime \prime}$ & 19.5 & Coarse gravel & 0 & 0 & 2 & 7 & 11 & 14 \\
\hline 431306071213001 & SRM-120R & & & $<0.063$ & Silt & 88 & 97 & 100 & & & \\
\hline 431302071213501 & SRM-130L & & & 0.478 & Medium sand & 1 & 5 & 29 & 52 & 64 & 70 \\
\hline 431302071213501 & SRM-130C & $4313^{\prime} 01.5^{\prime \prime}$ & $-7121^{\prime} 35.2^{\prime \prime}$ & 11.75 & Medium gravel & 1 & 3 & 12 & 19 & 22 & 23 \\
\hline 431302071213501 & SRM-130R & & & 0.714 & Coarse sand & 5 & 13 & 26 & 41 & 62 & 73 \\
\hline 431301071214201 & SRM-140L & & & 0.482 & Medium sand & 17 & 19 & 24 & 52 & 75 & 89 \\
\hline 431301071214201 & SRM-140C & $4313^{\prime} 01.4^{\prime \prime}$ & $-7121^{\prime} 41.6^{\prime \prime}$ & 15 & Very coarse gravel & 0 & 0 & 1 & 2 & 2 & 2 \\
\hline 431301071214201 & SRM-140R & & & 0.067 & Very fine sand & 49 & 63 & 69 & 83 & 97 & 100 \\
\hline 431254071215201 & SRM-200L & & & 0.245 & Fine sand & 1 & 5 & 52 & 93 & 100 & \\
\hline 431254071215201 & SRM-200C & $4312^{\prime} 53.6^{\prime \prime}$ & $-7121^{\prime} 52.3^{\prime \prime}$ & 0.85 & Coarse sand & 2 & 8 & 19 & 36 & 56 & 71 \\
\hline 431254071215201 & SRM-200R & & & 0.154 & Fine sand & 13 & 40 & 83 & 100 & & \\
\hline 431246071220201 & SRM-210L & & & 0.226 & Fine sand & 6 & 20 & 57 & 95 & 100 & \\
\hline 431246071220201 & SRM-210C & $4312^{\prime} 45.7^{\prime \prime}$ & $-7122^{\prime} 02.4^{\prime \prime}$ & 1.1667 & Very coarse sand & 2 & 5 & 12 & 27 & 47 & 65 \\
\hline 431246071220201 & SRM-210R & & & 0.153 & Fine sand & 10 & 38 & 91 & 100 & & \\
\hline 431237071221101 & SRM-220L & & & 0.197 & Fine sand & 4 & 19 & 73 & 98 & 100 & \\
\hline 431237071221101 & SRM-220C & $4312^{\prime} 37.4^{\prime \prime}$ & $-7122^{\prime} 11.0^{\prime \prime}$ & 1.333 & Very coarse sand & 1 & 3 & 15 & 32 & 44 & 62 \\
\hline 431237071221101 & SRM-220R & & & 0.192 & Fine sand & 4 & 20 & 76 & 99 & 100 & \\
\hline 431236071221301 & SRM-230L & & & 4.291 & Fine gravel & 2 & 7 & 20 & 33 & 44 & 46 \\
\hline 431236071221301 & SRM-230C & $4312^{\prime} 35.6^{\prime \prime}$ & $-7122^{\prime} 12.6^{\prime \prime}$ & 16 & Medium gravel & 0 & 0 & 4 & 12 & 24 & 29 \\
\hline 431236071221301 & SRM-230R & & & 0.148 & Fine sand & 10 & 40 & 95 & 100 & & \\
\hline
\end{tabular}


Suncook River.-Continued

>, greater than; L, left bank; C, channel; R, right bank]

Particle size (mm)

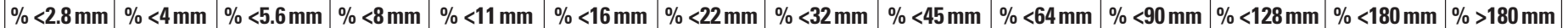

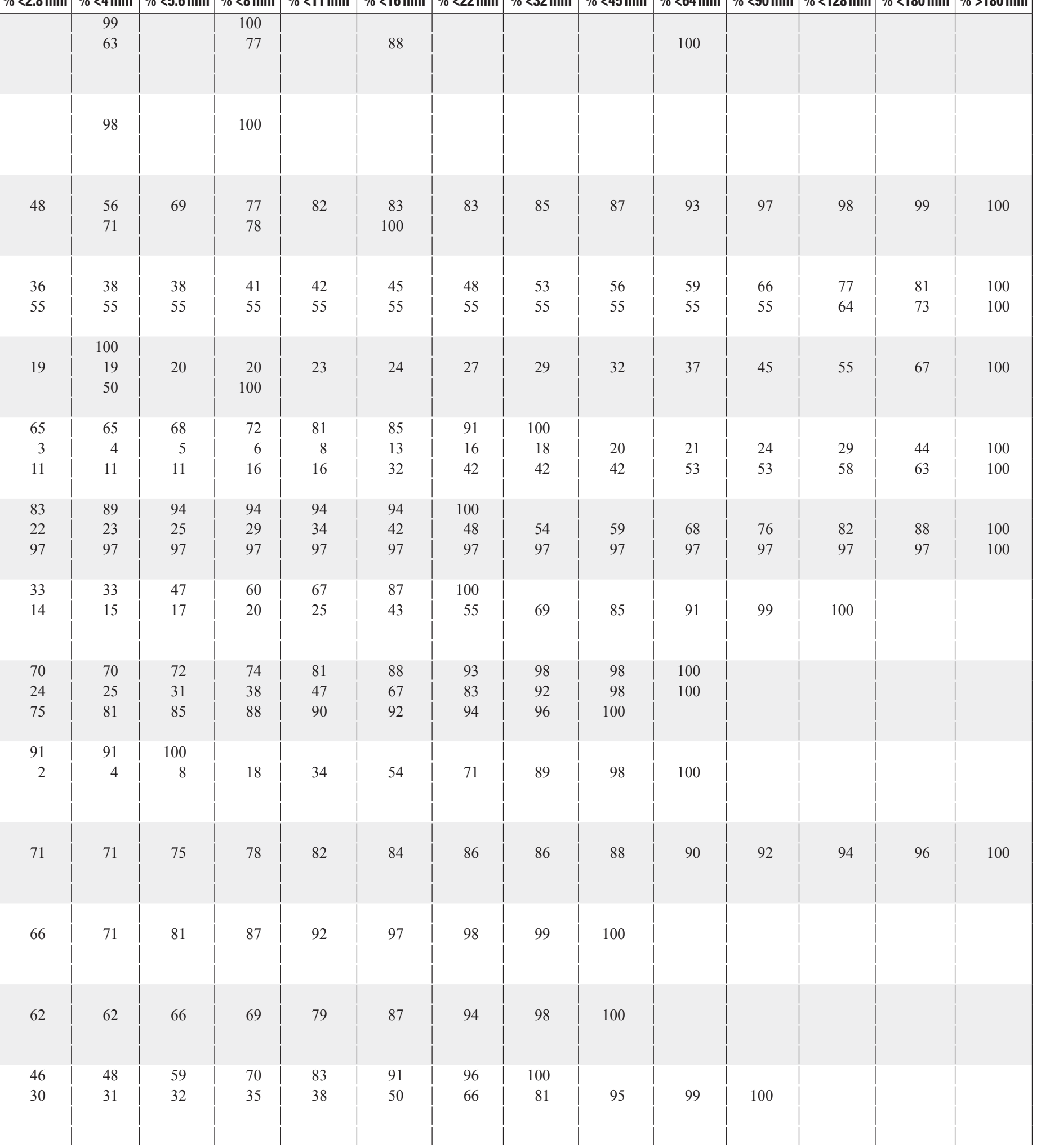


Appendix 1. Particle-size gradation and median diameter $\left(d_{50}\right)$ of streambed sediment samples collected at 30 locations in the [coord dms, coordinates in degrees, minutes, seconds; ID, identification number; $\mathrm{N}$, north; W, west; mm, millimeters; \%, percent; <, less than; m, meters;

\begin{tabular}{|c|c|c|c|c|c|c|c|c|c|c|c|}
\hline \multirow{2}{*}{$\begin{array}{c}\text { Site ID } \\
\text { (coord dms) }\end{array}$} & \multirow{2}{*}{ Old ID } & \multirow{2}{*}{$\begin{array}{l}\text { Latitude } \\
\text { (N) }\end{array}$} & \multirow{2}{*}{$\begin{array}{l}\text { Longitude } \\
\text { (W) }\end{array}$} & \multirow{2}{*}{$\begin{array}{c}d_{50} \\
(\mathrm{~mm})\end{array}$} & \multirow{2}{*}{$\begin{array}{l}\boldsymbol{d}_{50} \text { sediment } \\
\text { class name }\end{array}$} & \multicolumn{6}{|c|}{ Particle size (mm) } \\
\hline & & & & & & $\%<63 \mathrm{~m}$ & $\%<125 \mathrm{~m}$ & $\%<250 \mathrm{~m}$ & $\%<500 \mathrm{~m}$ & $\%<1 \mathrm{~mm}$ & $\%<2 \mathrm{~mm}$ \\
\hline 431215071221601 & SRM-232L & & & 0.394 & Medium sand & 4 & 9 & 31 & 64 & 82 & 88 \\
\hline 431215071221601 & SRM-232C & $4312^{\prime} 15.3^{\prime \prime}$ & $-7122^{\prime} 16.5^{\prime \prime}$ & 1.273 & Very coarse sand & 0 & 0 & 6 & 29 & 47 & 58 \\
\hline 431215071221601 & SRM-232R & & & 0.104 & Very fine sand & 21 & 65 & 98 & 100 & & \\
\hline 431221071224401 & SRM-234L & & & 0.132 & Fine sand & 12 & 48 & 85 & 94 & 100 & \\
\hline 431221071224401 & SRM-234C & $4312^{\prime} 21.0^{\prime \prime}$ & $-7122^{\prime} 43.9^{\prime \prime}$ & 0.704 & Coarse sand & 0 & 0 & 3 & 30 & 79 & 96 \\
\hline 431221071224401 & SRM-234R & & & 0.125 & Fine sand & 15 & 50 & 93 & 100 & & \\
\hline 431202071225601 & SRM-238L & & & 0.206 & Fine sand & 6 & 26 & 63 & 78 & 89 & 97 \\
\hline 431202071225601 & SRM-238C & $4312^{\prime} 01.6^{\prime \prime}$ & $-7122^{\prime} 56.2^{\prime \prime}$ & 0.6875 & Coarse sand & 0 & 0 & 4 & 35 & 75 & 95 \\
\hline 431202071225601 & SRM-238R & & & 0.291 & Medium sand & 8 & 17 & 44 & 81 & 97 & 100 \\
\hline 431142071225101 & SRM-240L & & & & & 25 & & & & & \\
\hline 431142071225101 & SRM-240C & $4311^{\prime} 41.6^{\prime \prime}$ & $-7122^{\prime} 50.9^{\prime \prime}$ & 0.230 & Fine sand & 1 & 7 & 58 & 84 & 92 & 96 \\
\hline 431142071225101 & SRM-240R & & & 0.107 & Very fine sand & 21 & 62 & 94 & 98 & 100 & \\
\hline 431121071225401 & SRM-250L & & & 0.095 & Very fine sand & 22 & 75 & 97 & 99 & 100 & \\
\hline 431121071225401 & SRM-250C & $4311^{\prime} 21.4^{\prime \prime}$ & $-7122^{\prime} 54.2^{\prime \prime}$ & 0.460 & Medium sand & 1 & 3 & 13 & 57 & 92 & 99 \\
\hline 431121071225401 & SRM-250R & & & 0.094 & Very fine sand & 27 & 72 & 95 & 98 & 99 & 100 \\
\hline 431031071232001 & SRM-260L & & & & & 25 & & & & & \\
\hline 431031071232001 & SRM-260C & $4310^{\prime} 31.2^{\prime \prime}$ & $-7123^{\prime} 20.2^{\prime \prime}$ & NA & & 30 & & & & & \\
\hline 431031071232001 & SRM-260R & & & & & 35 & & & & & \\
\hline 431008071240201 & SRM-270L & & & 0.172 & Fine sand & 14 & 32 & 80 & 99 & 100 & \\
\hline 431008071240201 & SRM-270C & $4310^{\prime} 08.5^{\prime \prime}$ & $-7124^{\prime} 01.7^{\prime \prime}$ & NA & & 40 & & & & & \\
\hline 431008071240201 & SRM-270R & & & 0.141 & Fine sand & 23 & 45 & 83 & 98 & 99 & 99 \\
\hline 430938071241901 & SRM-280L & & & 0.114 & Very fine sand & 21 & 56 & 89 & 95 & 98 & 100 \\
\hline 430938071241901 & SRM-280C & $4309^{\prime} 37.5^{\prime \prime}$ & $-7124^{\prime} 18.6^{\prime \prime}$ & $<0.063$ & Coarse silt & 54 & & & & & 100 \\
\hline 430938071241901 & SRM-280R & & & 0.172 & Fine sand & 10 & 32 & 80 & 99 & 99 & 100 \\
\hline 430929071242601 & SRM-300L & & & 0.176 & Find sand & 20 & 33 & 75 & 99 & 100 & \\
\hline 430929071242601 & SRM-300C & $4309^{\prime} 29.0^{\prime \prime}$ & $-7124^{\prime} 26.4^{\prime \prime}$ & 19.273 & Coarse gravel & 1 & 2 & 4 & 10 & 14 & 16 \\
\hline 430929071242601 & SRM-300R & & & 0.156 & Find sand & 15 & 40 & 80 & 98 & 99 & 100 \\
\hline 430856071244701 & SRM-310L & & & $<0.063$ & Silt & 57 & & & & & \\
\hline 430856071244701 & SRM-310C & $4308^{\prime} 56.2^{\prime \prime}$ & $-7124^{\prime} 47.2^{\prime \prime}$ & 0.398 & Medium sand & 5 & 11 & 24 & 68 & 89 & 92 \\
\hline 430856071244701 & SRM-310R & & & 0.164 & Find sand & 9 & 32 & 89 & 99 & 100 & \\
\hline 430858071252501 & SRM-320L & & & 0.09 & Very fine sand & 35 & 69 & 94 & 98 & 99 & 100 \\
\hline 430858071252501 & SRM-320C & $4308^{\prime} 57.6^{\prime \prime}$ & $-7125^{\prime} 24.8^{\prime \prime}$ & 0.979 & Coarse sand & 1 & 3 & 10 & 27 & 51 & 70 \\
\hline 430858071252501 & SRM-320R & & & 0.123 & Very fine sand & 23 & 51 & 85 & 96 & 99 & 100 \\
\hline 430835071253401 & SRM-330L & & & 0.226 & Find sand & 7 & 16 & 58 & 97 & 100 & \\
\hline 430835071253401 & SRM-330C & $4308^{\prime} 35.0^{\prime \prime}$ & $-7125^{\prime} 33.6^{\prime \prime}$ & 0.85 & Coarse sand & 0 & 1 & 1 & 15 & 65 & 91 \\
\hline 430835071253401 & SRM-330R & & & 0.168 & Find sand & 12 & 33 & 82 & 98 & 100 & \\
\hline 430813071255201 & SRM-340L & & & & & 36 & & & & & \\
\hline 430813071255201 & SRM-340C & $4308^{\prime} 12.9^{\prime \prime}$ & $-7125^{\prime} 52.2^{\prime \prime}$ & 0.774 & Coarse sand & 2 & 5 & 20 & 33 & 64 & 89 \\
\hline 430813071255201 & SRM-340R & & & 0.14 & Find sand & 21 & 46 & 79 & 96 & 99 & 100 \\
\hline 430747071262101 & SRM-350L & & & & & 23 & & & & & \\
\hline 430747071262101 & SRM-350C & $4307^{\prime} 47.4^{\prime \prime}$ & $-7126^{\prime} 20.8^{\prime \prime}$ & 0.616 & Coarse sand & 0 & 0 & 1 & 37 & 93 & 100 \\
\hline 430747071262101 & SRM-350R & & & 0.226 & Find sand & 9 & 17 & 58 & 96 & 99 & 100 \\
\hline 1089985 & at Route 3 & & & 0.384 & Medium sand & 1 & 3 & 20 & 76 & 97 & 99 \\
\hline 430746071265901 & SRM-360C & $4307^{\prime} 46.5^{\prime \prime}$ & $-7126^{\prime} 58.9^{\prime \prime}$ & 0.409 & Medium sand & 7 & 11 & 20 & 67 & 91 & 99 \\
\hline
\end{tabular}


Suncook River-—Continued

>, greater than; L, left bank; C, channel; R, right bank]

Particle size (mm)

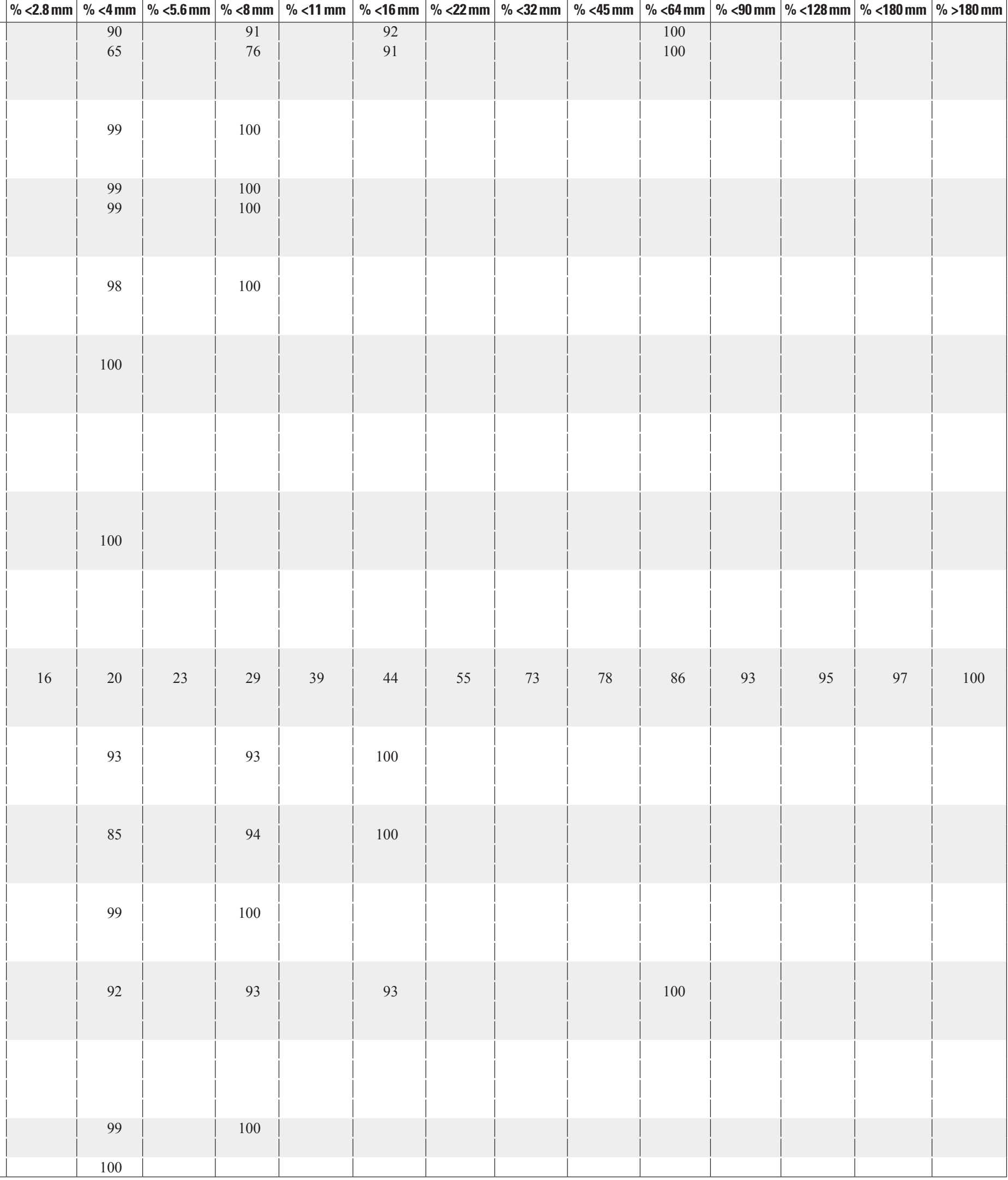


Prepared by the Pembroke Publishing Service Center.

For more information concerning this report, contact:

Director

U.S. Geological Survey

New Hampshire-Vermont Water Science Center

331 Commerce Way, Suite 2

Pembroke, NH 03275

dc_nh@usgs.gov

or visit our Web site at:

http://nh.water.usgs.gov 


\section{㞭}

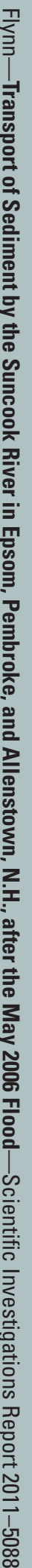

8 Printed on recycled paper

ISBN 1-41]3-3265-5 